Cochrane Database of Systematic Reviews

\title{
Interventions during pregnancy to prevent preterm birth: an overview of Cochrane systematic reviews (Review)
}

Medley N, Vogel JP, Care A, Alfirevic Z

Medley N, Vogel JP, Care A, Alfirevic Z.

Interventions during pregnancy to prevent preterm birth: an overview of Cochrane systematic reviews.

Cochrane Database of Systematic Reviews 2018, Issue 11. Art. No.: CD012505.

DOI: 10.1002/14651858.CD012505.pub2.

www.cochranelibrary.com 
TABLE OF CONTENTS

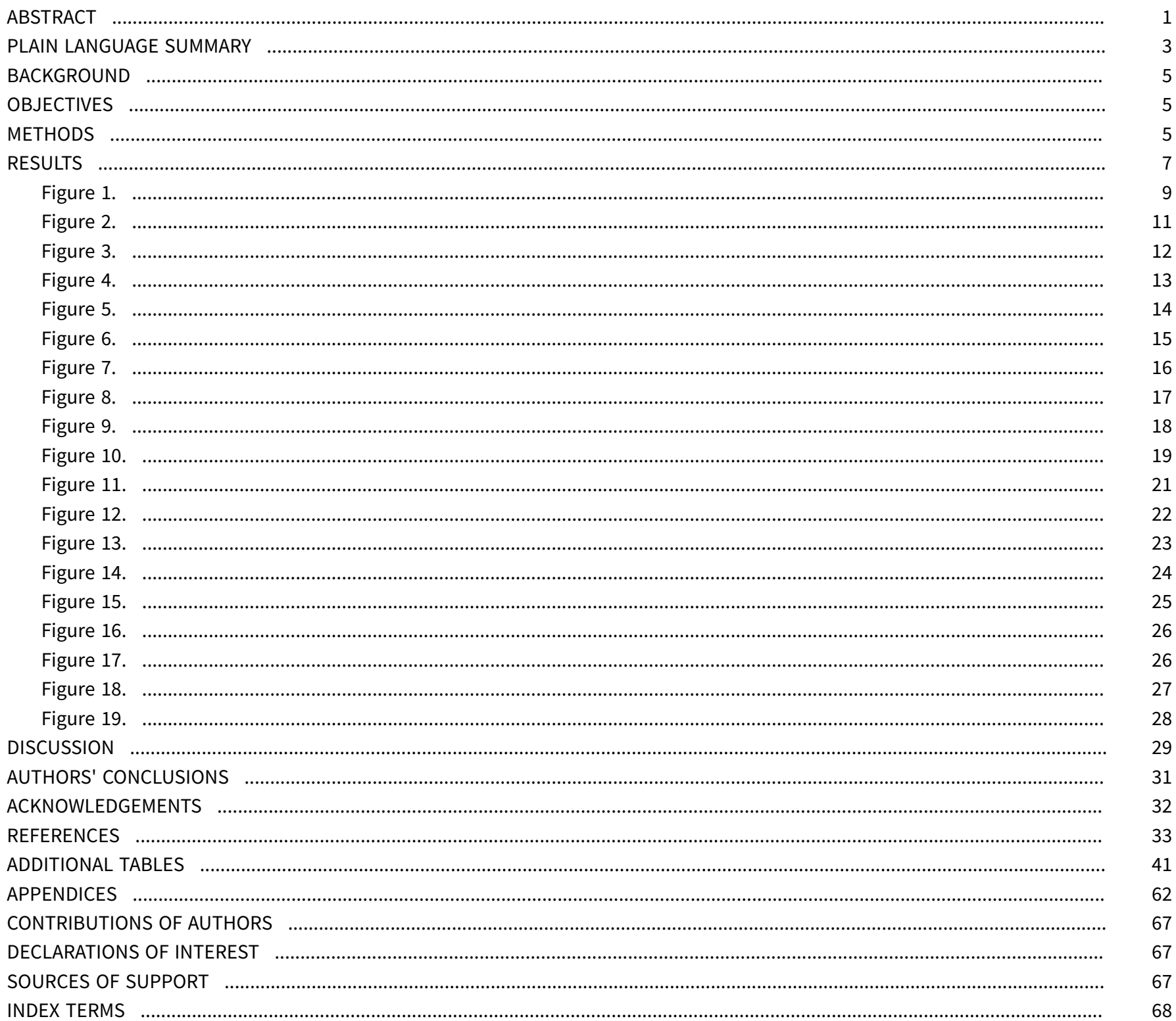


[Overview of Reviews]

\section{Interventions during pregnancy to prevent preterm birth: an overview of Cochrane systematic reviews}

Nancy Medley ${ }^{1}$, Joshua P Vogel 2 , Angharad Care ${ }^{3}$, Zarko Alfirevic ${ }^{3}$

1Cochrane Pregnancy and Childbirth Group, Department of Women's and Children's Health, The University of Liverpool, Liverpool, UK. 2Maternal and Child Health, Burnet Institute, Melbourne, Australia. ${ }^{3}$ Department of Women's and Children's Health, The University of Liverpool, Liverpool, UK

Contact: Nancy Medley, Cochrane Pregnancy and Childbirth Group, Department of Women's and Children's Health, The University of Liverpool, First Floor, Liverpool Women's NHS Foundation Trust, Crown Street, Liverpool, L8 7SS, UK. nmedley2@liverpool.ac.uk.

Editorial group: Cochrane Pregnancy and Childbirth Group.

Publication status and date: New, published in Issue 11, 2018.

Citation: Medley N, Vogel JP, Care A, Alfirevic Z. Interventions during pregnancy to prevent preterm birth: an overview of Cochrane systematic reviews. Cochrane Database of Systematic Reviews 2018, Issue 11. Art. No.: CD012505. DOI: 10.1002/14651858.CD012505.pub2.

Copyright @ 2018 The Cochrane Collaboration. Published by John Wiley \& Sons, Ltd.

\section{A B S T R A C T}

\section{Background}

Preterm birth (PTB) is a major factor contributing to global rates of neonatal death and to longer-term health problems for surviving infants. Both the World Health Organization and the United Nations consider prevention of PTB as central to improving health care for pregnant women and newborn babies. Current preventative clinical strategies show varied efficacy in different populations of pregnant women, frustrating women and health providers alike, while researchers call for better understanding of the underlying mechanisms that lead to PTB.

\section{Objectives}

We aimed to summarise all evidence for interventions relevant to the prevention of PTB as reported in Cochrane systematic reviews (SRs). We intended to highlight promising interventions and to identify SRs in need of an update.

\section{Methods}

We searched the Cochrane Database of Systematic Reviews (2 November 2017) with key words to capture any Cochrane SR that prespecified or reported a PTB outcome. Inclusion criteria focused on pregnant women without signs of preterm labour or ruptured amniotic membranes. We included reviews of interventions for pregnant women irrespective of their risk status. We followed standard Cochrane methods.

We applied GRADE criteria to evaluate the quality of SR evidence. We assigned graphic icons to classify the effectiveness of interventions as: clear evidence of benefit; clear evidence of harm; clear evidence of no effect or equivalence; possible benefit; possible harm; or unknown benefit or harm. We defined clear evidence of benefit and clear evidence of harm to be GRADE moderate- or high-quality evidence with a confidence interval $(\mathrm{Cl})$ that does not cross the line of no effect. Clear evidence of no effect or equivalence is GRADE moderate- or highquality evidence with a narrow $\mathrm{Cl}$ crossing the line of no effect. Possible benefit and possible harm refer to GRADE low-quality evidence with a clear effect ( $\mathrm{Cl}$ does not cross the line of no effect) or GRADE moderate- or high-quality evidence with a wide $\mathrm{Cl}$. Unknown harm or benefit refers to GRADE low- or very low-quality evidence with a wide $\mathrm{CI}$.

\section{Main results}

We included 83 SRs; 70 had outcome data. Below we highlight key results from a subset of 36 SRs of interventions intended to prevent PTB.

\section{Outcome: preterm birth}


Clear evidence of benefit

Four SRs reported clear evidence of benefit to prevent specific populations of pregnant women from giving birth early, including midwifeled continuity models of care versus other models of care for all women; screening for lower genital tract infections for pregnant women less than 37 weeks' gestation and without signs of labour, bleeding or infection; and zinc supplementation for pregnant women without systemic illness. Cervical cerclage showed clear benefit for women with singleton pregnancy and high risk of PTB only.

Clear evidence of harm

No included SR reported clear evidence of harm.

No effect or equivalence

For pregnant women at high risk of PTB, bedrest for women with singleton pregnancy and antibiotic prophylaxis during the second and third trimester were of no effect or equivalent to a comparator.

Possible benefit

Four SRs found possible benefit in: group antenatal care for all pregnant women; antibiotics for pregnant women with asymptomatic bacteriuria; pharmacological interventions for smoking cessation for pregnant women who smoke; and vitamin D supplements alone for women without pre-existing conditions such as diabetes.

Possible harm

One SR reported possible harm (increased risk of PTB) with intramuscular progesterone, but this finding is only relevant to women with multiple pregnancy and high risk of PTB. Another review found possible harm with vitamin D, calcium and other minerals for pregnant women without pre-existing conditions.

\section{Outcome: perinatal death}

Clear evidence of benefit

Two SRs reported clear evidence of benefit to reduce pregnant women's risk of perinatal death: midwife-led continuity models of care for all pregnant women; and fetal and umbilical Doppler for high-risk pregnant women.

\section{Clear evidence of harm}

No included SR reported clear evidence of harm.

No effect or equivalence

For pregnant women at high risk of PTB, antibiotic prophylaxis during the second and third trimester was of no effect or equivalent to a comparator.

Possible benefit

One SR reported possible benefit with cervical cerclage for women with singleton pregnancy and high risk of PTB.

Possible harm

One SR reported possible harm associated with a reduced schedule of antenatal visits for pregnant women at low risk of pregnancy complications; importantly, these women already received antenatal care in settings with limited resources.

\section{Outcomes: preterm birth and perinatal death}

Unknown benefit or harm

For pregnant women at high risk of PTB for any reason including multiple pregnancy, home uterine monitoring was of unknown benefit or harm. For pregnant women at high risk due to multiple pregnancy: bedrest, prophylactic oral betamimetics, vaginal progesterone and cervical cerclage were all of unknown benefit or harm.

\section{Authors' conclusions}

Implications for practice

The overview serves as a map and guide to all current evidence relevant to PTB prevention published in the Cochrane Library. Of 70 SRs with outcome data, we identified 36 reviews of interventions with the aim of preventing PTB. Just four of these SRs had evidence of clear 
benefit to women, with an additional four SRs reporting possible benefit. No SR reported clear harm, which is an important finding for women and health providers alike.

The overview summarises no evidence for the clinically important interventions of cervical pessary, cervical length assessment and vaginal progesterone because these Cochrane Reviews were not current. These are active areas for PTB research.

The graphic icons we assigned to SR effect estimates do not constitute clinical guidance or an endorsement of specific interventions for pregnant women. It remains critical for pregnant women and their healthcare providers to carefully consider whether specific strategies to prevent PTB will be of benefit for individual women, or for specific populations of women.

Implications for research

Formal consensus work is needed to establish standard language for overviews of reviews and to define the limits of their interpretation.

Clinicians, researchers and funders must address the lack of evidence for interventions relevant to women at high risk of PTB due to multiple pregnancy.

\section{PLAIN LANGUAGE SUMMARY}

\section{Ways to help pregnant women avoid preterm birth}

\section{What is the issue?}

Preterm birth, or being born before 37 weeks of pregnancy, is a major reason why newborns die and may also mean long-term disability for surviving infants. There are many ways healthcare providers try to prevent women from having their babies too early. Pregnant women may be encouraged to take vitamins, reduce smoking, take medicines for infections or attend regular healthcare visits. Our overview looks at different ways (or interventions) to prevent preterm birth. We searched for relevant papers in the Cochrane Library on 2 November, 2017.

\section{Why is this important?}

Preterm birth is devastating and costly for women, families and health systems. We aimed to summarise relevant information for pregnant women, healthcare workers and researchers.

\section{What evidence did we find?}

We included 83 systematic reviews with evidence about whether or not the intervention was able to reduce pregnant women's chance of having a preterm birth or a baby death. Seventy of these reviews had information about preterm birth. We categorised the evidence we found as: clear benefit or harm; no effect; possible benefit or harm; or unknown effect.

\section{Outcome: preterm birth}

\section{Clear benefit}

We were confident that the following interventions were able to help specific populations of pregnant women avoid giving birth early: midwife-led continuity models of care versus other models of care for all women; screening for lower genital tract infections; and zinc supplementation for pregnant women without systemic illness. Cervical stitch (cerclage) was of benefit only for women at high risk of preterm birth and with singleton pregnancy.

\section{Clear harm}

We found no treatment that increased women's chance of giving birth preterm.

\section{Possible benefit}

The following interventions may have helped some groups of pregnant women avoid preterm birth, but we have less confidence in these results: group antenatal care for all pregnant women; antibiotics for pregnant women with asymptomatic bacteriuria; pharmacological interventions for smoking cessation; and vitamin D supplements alone for women without health problems.

Possible harm

We found two interventions that may have made things worse for some pregnant women: intramuscular progesterone for women at high risk of preterm birth with multiple pregnancy; and taking vitamin D supplements, calcium and other minerals for pregnant women without health problems.

\section{Outcome: perinatal death}

Clear benefit 
We were confident in evidence for midwife-led continuity models of care for all pregnant women; and for fetal and umbilical Doppler for high-risk pregnant women; these interventions appeared to reduce women's chance of experiencing baby death.

Clear harm

We found no intervention that increased women's risk of baby death.

Possible benefit

We found a possible benefit with cervical stitch (cerclage) for women with singleton pregnancy and high risk of preterm birth.

Possible harm

One review reported possible harm associated with having fewer antenatal visits, even for pregnant women at low risk of pregnancy problems. The pregnant women in this review already received limited antenatal care.

\section{Outcomes: preterm birth and perinatal death}

Unknown benefit or harm

For pregnant women at high risk of preterm birth for any reason including multiple pregnancy, home uterine monitoring was of unknown benefit or harm. For high-risk pregnant women with multiple pregnancy: bedrest, prophylactic oral betamimetics, vaginal progesterone and cervical cerclage were all of unknown benefit or harm.

\section{What does this mean?}

There is valuable information in the Cochrane Library relevant to women, doctors, midwives and researchers interested in preventing early birth. We have summarised the results of systematic reviews to describe how well different strategies work to prevent early birth and baby death. We organised our information in clear figures with graphic icons to represent how confident we were in the results and to point readers toward promising treatments for specific groups of pregnant women.

Our overview found no up-to-date information in the Cochrane Library for the important treatments of cervical pessary, vaginal progesterone or cervical assessment with ultrasound. We found no high-quality evidence relevant to women at high risk of preterm birth due to multiple pregnancy. It remains important for pregnant women and their healthcare providers to carefully consider whether specific strategies to prevent preterm birth will be of benefit for individual women, or for specific populations of women. 


\section{B A C K G R O U N D}

Preterm birth (PTB) places a substantial burden on economies, health systems and families worldwide. PTB contributes disproportionately to global rates of neonatal death, and infants who survive early birth may suffer serious complications and long-term disability (Blencowe 2013; Liu 2015). PTB cost the UK economy $£ 2.9$ billion in a single year (Mangham 2009), while affected families suffered equally profound financial, social and psychological consequences (Carson 2015; Hodek 2011; Vigod 2010).

The World Health Organization (WHO) identified PTB as a "top ten" research priority to 2025 (Yoshida 2016). The United Nations has also positioned PTB research as central to achieving a reduction in newborn deaths and the Sustainable Development Goals to 2030 (Lawn 2016). Though the PTB rate in countries such as the USA has fallen, early birth contributes to high mortality in low- and middleincome countries (Blencowe 2012; Gyamfi-Bannerman 2014). The March of Dimes and the International Federation of Gynecology and Obstetrics Working Group urge researchers to think beyond current clinical and preventive strategies and to expand basic research to develop new interventions for PTB (Ferrero 2016; Martin 2017).

\section{Description of the condition}

PTB is usually defined as birth before 37 weeks +0 days gestation (or 259 days) (Anonymous 1977). The Global Alliance to Prevent Prematurity and Stillbirth (GAPPS) defined 'providerinitiated' PTB as early births related to: severe maternal, fetal or placental conditions, maternal request, breech presentation, cephalopelvic disproportion, or previous caesarean section. In contrast, 'spontaneous' preterm births (SPTB) were not related to severe clinical conditions (Villar 2012). When applied to 60,000+ births, the GAPPS classification system found $22 \%$ of all early births to occur spontaneously and without association to any severe condition (Barros 2015).

This overview is concerned with sPTB rather than provider-initiated PTB, but in practice the early births reported in included SRs may be a mix of the two. The United States Vital Statistics and the Office of National Statistics in the UK do not distinguish spontaneous from provider-initiated PTB when reporting national rates. A recent US study makes the distinction, but the PTB Core Outcome Set does not (Gyamfi-Bannerman 2014; van't Hooft 2016).

\section{Description of the interventions}

Many interventions to prevent PTB target all pregnant women; these may begin before or during pregnancy, such as folate supplementation or improved access to antenatal care (lams 2008). Other interventions target specific populations of pregnant women considered to be at higher risk of PTB, such as women with multiple pregnancy or women who smoke. This overview will include all interventions that could be applied during pregnancy to prevent PTB, regardless of women's risk factors. In this overview, we included interventions for women with co-morbid conditions such as diabetes or hypertension, for women with recognised risk factors such as short cervix or multiple pregnancy, and for pregnant women without any known risk.

\section{How the intervention might work}

We do not fully understand the pathways leading to PTB, which limits implementation of appropriate clinical and public health prevention strategies. Interventions may reduce PTB via diverse pathways. Nutritional supplements may modify low body mass index (BMI) to reduce risk, while screening for asymptomatic bacteriuria may reduce the risk of infection-related PTB. We included SRs of interventions regardless of whether the mechanism of action on PTB was known.

\section{Why it is important to do this overview}

We aim to improve the care of pregnant women. There is a wealth of information in the Cochrane Library relevant to PTB prevention. Initial searches returned over $800 \mathrm{SRs}$, and yet there is no efficient way for researchers, funding organisations, clinicians or pregnant women themselves to quickly access this evidence. This overview extends previous efforts to catalogue SRs of PTB interventions (lams 2008; Piso 2014) and applies the agreed core outcome set for PTB (van't Hooft 2016).

\section{O B JECTIVES}

We aimed to summarise all evidence for interventions relevant to the prevention of PTB as reported in Cochrane systematic reviews (SRs). We intended to highlight promising interventions and to identify SRs in need of an update.

\section{METHODS}

\section{Criteria for considering reviews for inclusion}

We applied the inclusion and exclusion criteria below when assessing SRs for this overview.

\begin{tabular}{|c|c|c|c|}
\hline Eligibility & & Inclusion & Exclusion \\
\hline \multirow[t]{3}{*}{ Participant level } & Population & $\begin{array}{l}\text { Pregnant women including those } \\
\text { with risk factors or co-morbidities }\end{array}$ & $\begin{array}{l}\text { Pregnant women with acute signs of preterm } \\
\text { labour }\end{array}$ \\
\hline & & $\begin{array}{l}\text { Pregnant women with singleton or } \\
\text { multiple pregnancy }\end{array}$ & $\begin{array}{l}\text { Pregnant women with a previous episode of } \\
\text { preterm labour in current pregnancy }\end{array}$ \\
\hline & & Healthcare providers & $\begin{array}{l}\text { Pregnant women with preterm prelabour rup- } \\
\text { tured membranes (PPROM) }\end{array}$ \\
\hline
\end{tabular}

Pregnant women with major fetal anomalies 
Pregnant women undergoing induction of labour

Review level Review Cochrane systematic reviews pub-
lished from 2014
We listed reviews with a relevant population and intervention published before 2014 or with a search date prior to 2014

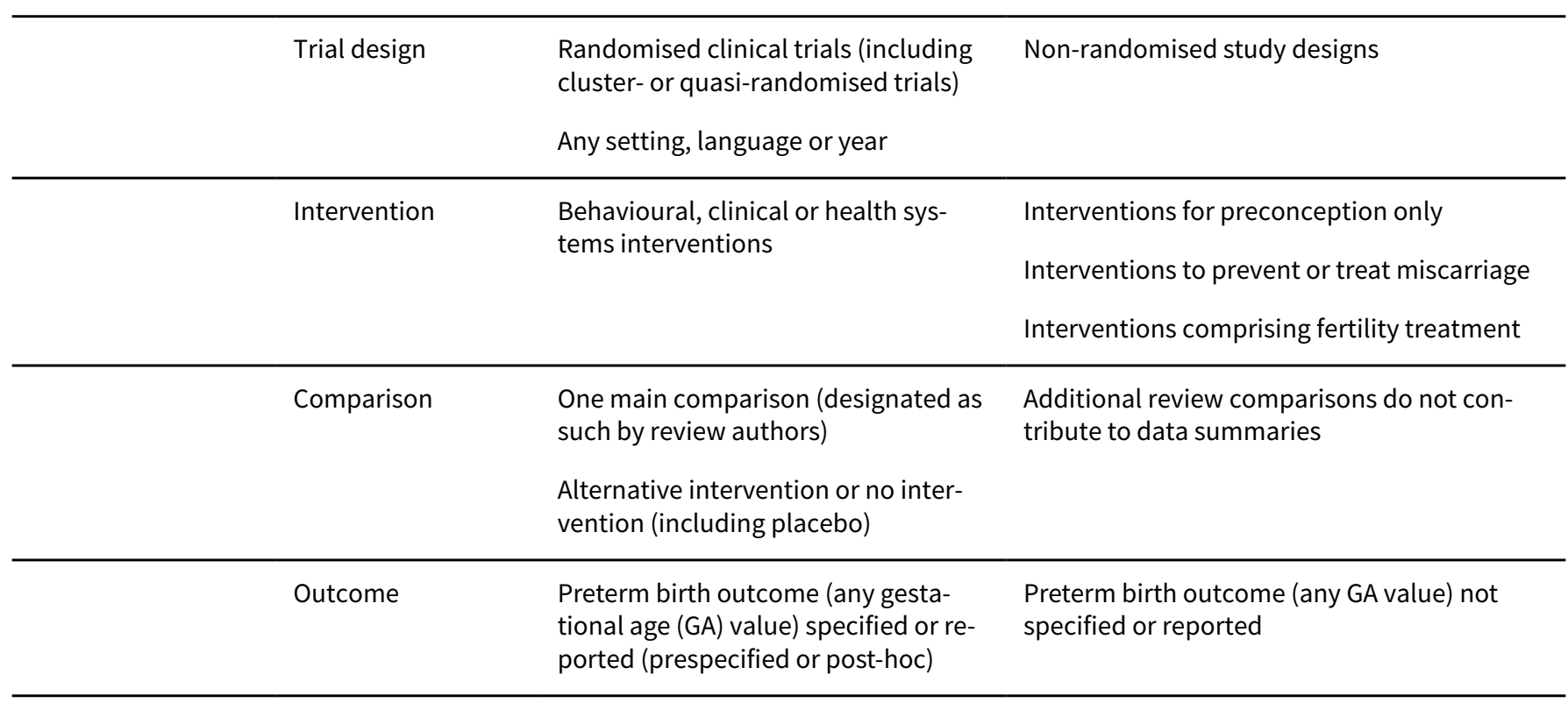

The inclusion and exclusion criteria define a pregnant population without signs of preterm labour. We excluded SRs of interventions for women with PPROM because these women receive individualised management with interventions with a short timeframe to delivery and, often, the goal of improving neonatal outcomes (e.g. magnesium sulphate for neuro protection). We excluded reviews of interventions targeting the neonate.

\section{Search methods for identification of reviews}

Only Cochrane systematic reviews were eligible for inclusion in this overview. We searched the Cochrane Database of Systematic Reviews (2 November 2017) with a broad strategy using all possible keywords to capture reviews relevant to preterm birth (see Appendix 1).

\section{Data collection and analysis}

We followed standard methods for overviews of reviews as described below.

\section{Selection of reviews}

We conducted eligibility in duplicate with all conflicts resolved through discussion with a third overview author.

We staged eligibility assessment. First, two overview authors assessed titles and abstracts to ensure that SRs targeted appropriate populations of pregnant women and summarised relevant interventions. Second, we set aside all relevant Cochrane protocols; we will check the status of these in future updates of this overview. We set aside potentially relevant titles published before 2014. Finally, we assessed the full text of remaining reviews to explore further whether the population and intervention met our inclusion criteria and to confirm that the review included randomised trial evidence. We list characteristics of reviews excluded at full-text assessment.

\section{Data extraction and management}

For each included SR one overview author (NM) independently extracted data; a second overview author checked the data for accuracy. We resolved disagreements by discussion. We extracted the following characteristics from each included SR.
1. Search date
2. Number of trials included in the review
3. Number of participants included in the review
4. Overview outcomes with data
5. Authors' conclusions

Two overview authors piloted the data synthesis tables to improve the content and presentation of SR results. When the final format was agreed amongst all overview authors, one overview author created figures to present outcome data and a second overview author checked the figures.

\section{Assessment of methodological quality of included reviews Methodological quality of included systematic reviews}

Several recent publications have explored problems with the AMSTAR tool for assessing systematic review (SR) quality (Burda 2016; Faggion 2015; Pollock 2017; Shea 2007; Wegewitz 2016). Because of the identified shortcomings of AMSTAR, we decided against using it and explored using the Risk of Bias in Systematic Reviews (ROBIS) quality checklist instead. 
ROBIS users first establish the relevance of the systematic review (SR) by checking that the population, intervention, comparator and outcomes align between the review and overview. Next, researchers use ROBIS to consider review methods: study eligibility criteria; identification and selection of studies; data collection and study appraisal; and synthesis and findings. Key questions within each of these four domains sum to an overall risk of bias for the review. Throughout, the tool prompts assessors to flag specific concerns. Finally, ROBIS requires the assessors to weigh their concerns with SR methods alongside SR conclusions for a judgement of low, high or unclear risk of bias (Whiting 2016).

\section{Quality of trial evidence included in reviews}

We did not reassess the risks of bias for the individual trials included in eligible SRs. 'Risk of bias' assessment is a component of all Cochrane Reviews; review authors consider aspects of trial conduct and reporting and note whether bias may have impacted the trial's reported effect estimates (Higgins 2011a). Further, when we evaluated pooled outcome data from a particular SR, we made use of the review authors' GRADE assessments. GRADE incorporates the review authors' 'Risk of bias' judgements for individual trials comprising pooled estimates. Where review authors did not undertake GRADE, we ourselves reviewed pooled summary statistics and trials' risks of bias according to criteria described in the GRADE Handbook (Schünemann 2013).

\section{Data synthesis}

\section{Types of outcomes}

We included Cochrane systematic reviews that specified or reported preterm birth (PTB) as one of the outcome measures. We planned to include all core outcome set domains for effectiveness, safety, maternal satisfaction and economic costs (van't Hooft 2016). Due to variation in outcome definition and reporting, and to the large number of included SRs, we present outcome data for PTB (any gestational age (GA) value) and perinatal death (PD), only (PD includes stillbirth and neonatal death). Formal consensus work with diverse stakeholders (including parents, midwives and other health professionals) confirmed GA at delivery and offspring mortality as the top two clinical outcomes for evaluating interventions to prevent preterm birth (van't Hooft 2016). Updates of this overview will explore adding additional outcome domains and/or specific outcome measures. As stated above, we expect most SR reporting of PTB outcomes may include both spontaneous and provider-initiated early births.

\section{Data synthesis and presentation}

We planned to structure data synthesis as in other Cochrane overviews (Farquhar 2018; Jones 2012; Lassi 2015; Welsh 2015). Due to the large number of included SRs, we instead created figures to present review data visually. We assigned graphic icons to communicate the direction of review effect estimates and our confidence in the available data. The graphic icons indicate mutually exclusive assessment categories: clear evidence of benefit; clear evidence of harm; clear evidence of no effect or equivalence; possible benefit; possible harm; or unknown benefit or harm. Our presentation of data is modelled on graphics produced by the WHO to describe different types of workers and their roles in maternal and newborn care (http://optimizemnh.org/ optimizing-health-worker-roles-maternal-newborn-health/).
We separated SRs of interventions to prevent PTB from SRs of interventions targeting other problems during pregnancy. We then organised SR outcome data in figures according to type of intervention: device, health systems, lifestyle, medicines, multiple interventions, nutrition, screening, psychosocial, and surgical. The category of 'multiple' interventions includes SRs where different types of interventions were tested for a particular problem; for example, the SR of interventions to prevent nausea in pregnancy included both drug and acupressure interventions.

To assign a graphic icon we first considered the pooled summary statistic and confidence interval, any GRADE judgements made by the review author team and the amount of information present:the number of trials, women and events contributing to the metaanalysis. GRADE criteria include: study design limitations in trials contributing data; imprecision of effects (wide confidence intervals, sparse data or both); inconsistency (unexplained heterogeneity as measured by the $\mathrm{I}^{2}$ statistic); indirectness (when trials test a different population, intervention, comparison or outcome than is specified in the review); and publication bias. All randomised trial evidence begins as of high certainty but may be downgraded by one for a 'serious' problem or by two for 'very serious' problem with any of these criteria. The GRADEpro Guideline Development Tool sums downgrading decisions into a quality rating of high, moderate, low, or very low (Schünemann 2013).

There is a large literature on conducting, interpreting and communicating GRADE assessment (Guyatt 2011a; Santesso 2015a; Santesso 2015b). Researchers continue to explore ways to express SR effect estimates and to delineate the scope of their interpretation (Hultcrantz 2017). Our graphic icons communicate the GRADE quality assessment found in SR 'Summary of findings' tables. Where SR authors did not GRADE relevant trial evidence for PTB or PD, two overview authors independently applied GRADE criteria and resolved disagreement through discussion (GRADE assessments not shown).

For all included SRs, two overview authors independently assessed data for the outcomes of PD and PTB to assign a graphic icon. We resolved disagreements through discussion or by consultation with a third overview author.

\section{Limitations of the overview and bias in the review process}

One limitation of our overview is its restriction to Cochrane systematic reviews. Including all relevant, published SRs may have captured more current evidence on important topics. Cochrane Reviews are also all published in the English language. Finally, our search strategy did not include unpublished, industry and governmental SRs.

To minimise bias in the overview process, we followed standard review methods including duplication of effort. Where an overview author was also an author of a relevant SR, they were excluded from eligibility assessment and data synthesis for that SR.

\section{RE S U L T S}

\section{Search results}

We searched the Cochrane Database of Systematic Reviews (2 November 2017) with a list of key words to capture all systematic reviews (SRs) specifying or reporting any preterm birth (PTB) outcome (See Appendix 1 for the search strategy). We documented 
assessment of titles and full-text reviews in a study flow diagram (See Figure 1). We used Covidence software to manage eligibility assessment for 898 titles. Two overview authors independently assessed titles and full texts against prespecified inclusion and exclusion criteria. We resolved discrepancies between overview authors by discussion with a third author. No overview author assessed his or her own SR (several eligible reviews were authored by members of the overview team). 
Figure 1. Study flow diagram. Search date 2 November 2017

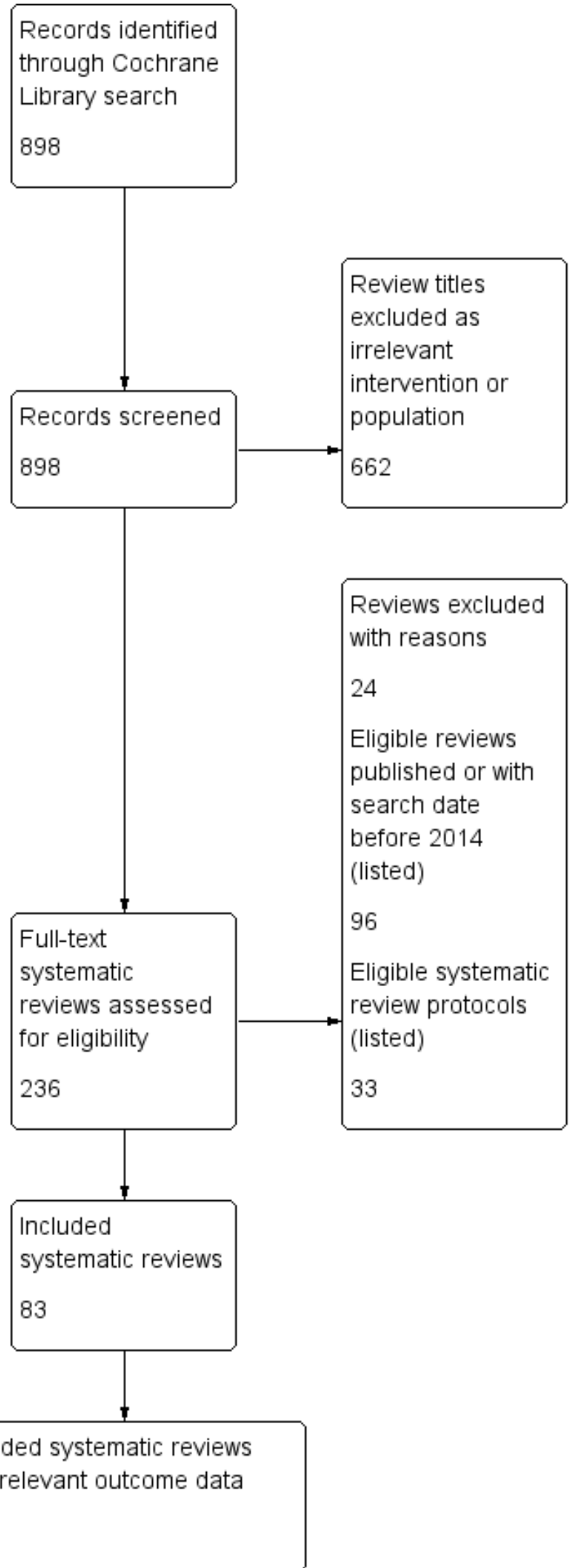


We included 83 SRs; their characteristics appear in Table 1; 70 included reviews reported relevant outcome data. We documented reasons for exclusion of 24 reviews at full-text assessment in Table 2. We identified 33 protocols for SRs potentially relevant to future versions of this overview; these titles will be assessed for future versions of the overview.

\section{Out-of-date systematic reviews}

Our protocol stated that we would apply a decision tree to potentially eligible but out-of-date reviews - SRs published before 2014 or with a search date before 2014. We found 96 reviews in this category. It was not feasible to conduct new searches for all of these reviews. Some reviews in this category are currently in the editorial process, while other reviews may summarise evidence for interventions no longer in use. We regret that we were unable to complete further assessment of these SR titles. As one peer reviewer pointed out - there may be interventions associated with harm in the list of out-of-date reviews, because authors would be less likely to complete new trials or to update reviews of interventions where there was known evidence of harm. We listed the titles in Appendix 2.

\section{Description of included reviews}

We documented key characteristics of 83 included studies in Table 1, including the search date, number of trials, number of women and the authors' conclusions about the effectiveness of the interventions. The language of authors' conclusions is directly quoted from the original Cochrane published reviews. Of 83 included SRs, seven had no randomised trials (i.e. these are 'empty reviews'). Six further SRs reported no trial data for either overview outcome of PTB or perinatal death (PD). All remaining 70 SRs contributed effect estimates for at least one overview outcome.

\section{Methodological quality of included reviews}

As noted above, researchers identified problems with the AMSTAR tool to assess SR quality (Burda 2016; Pollock 2017). We decided not to use AMSTAR and explored using the ROBIS tool instead. We decided against using ROBIS as well, because all SRs included in this overview followed standard methodology recommended in the Cochrane Handbook for Systematic Reviews of Interventions (Higgins 2011b). For more recent SR updates, review authors also followed methods set out by the Cochrane Editorial Unit (i.e. MECIR standards Higgins 2016). We are confident that all included SRs are of low risk of methods bias.

\section{Effect of interventions}

\section{Notes for Interpreting Graphic Icons \\ Graphic Icons}

We summarised systematic review (SR) evidence for the outcomes of PTB and PD by assigning one of six graphic icons to indicate our confidence in and interpretation of the available evidence. Figure 2 shows the icons and explains the mutually exclusive assessment categories. The first three categories represent GRADE moderateor high-quality evidence for which we found either clear benefit, clear harm or clear evidence of no effect (i.e. equivalence with a comparator). These categories are identified by a green tick, a red-cross and a green equal-sign icon, respectively. For 'clear' benefit or harm, the confidence interval associated with the effect size did not cross the line of no effect. For 'clear evidence of no effect or equivalence' we considered a confidence interval within the range of risk ratio (RR) 0.75 to 1.25 as sufficiently narrow to indicate a minimal effect relative to the comparator; these are thresholds recommended by GRADE (Guyatt 2011b). The overview author team individually discussed the handful of cases where an $\mathrm{SR}$ reported the odds ratio rather than relative risk. 
Figure 2. All icons by Freepik at www.flaticon.com.

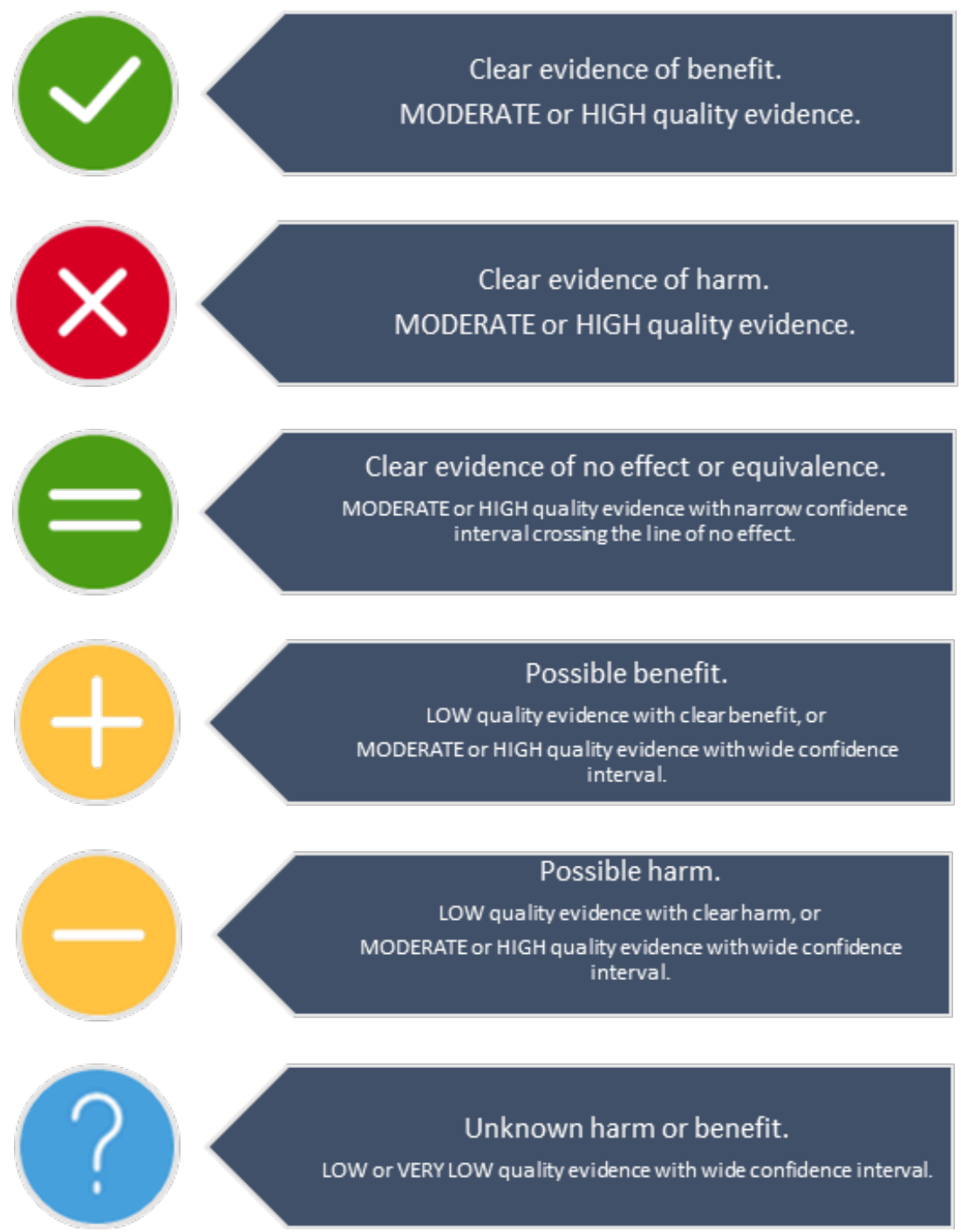

Continuing down Figure 2, two yellow icons represent evidence for which we had less confidence due to risks of bias in trials, imprecision or other GRADE criteria for downgrading evidence quality (Schünemann 2013). The yellow icons indicate possible benefit (the plus sign) or possible harm (the minus sign). Yellow icons represent GRADE moderate- or high-quality evidence when the confidence interval crossed the line of no effect. Yellow icons also represent GRADE low-quality evidence when the finding was of clear benefit or harm (i.e. the confidence interval did not cross RR 1.0). We must emphasise the reduced confidence and caution we intended to communicate when assigning the yellow graphic icons.

Finally, we assigned a blue question mark icon to indicate 'unknown harm or benefit' associated with the relative effect of an intervention versus a comparator. The blue question-mark icon indicates GRADE low-quality evidence with a confidence interval crossing the line of no effect as well as all GRADE very low-quality evidence.

\section{Evidence 'Quality' or 'Certainty'?}

Our categories of assessment follow GRADE ratings of high, moderate, low or very low to indicate the quality of evidence rather than its certainty. Though evidence quality and certainty are often used interchangeably, 'certainty' represents newer language that extends GRADE methods to the development of formal clinical guidance (Hultcrantz 2017). This overview does not constitute formal clinical guidance. The SR evidence summarised here would be considered "non-contextualised" rather than "contextualised" in the newer GRADE framework that aims to situate evidence in clinical, economic and geographic contexts.

SRs included in this overview applied GRADE criteria to a single outcome independently rather than to a set of critical outcomes valued together, as guideline developers might. SRs did not pre-specify thresholds for interpreting effect size or confidence intervals, and, though most SRs identified trial countries in their 'Summary of findings' tables, none reported this geographic information per outcome. No SR calculated a minimum information size required for meta-analysis. Most SRs did not incorporate formal analyses of the economic cost or of the acceptability of 
interventions to pregnant women. Finally, included Cochrane SRs do not make clinical recommendations (see Higgins 2011b, section 12.7.4 "Common errors in reaching conclusions").

Therefore, a GRADE of moderate or high quality in this overview reflects our confidence that the pooled estimate is correct (i.e. its 'quality') rather than an endorsement of the intervention's use in a specific clinical setting or population of pregnant women. Following this, the overview graphic icons do not represent clinical recommendations for the use of interventions. The graphic icons represent the quality of the evidence found in reviews and direct readers to the full text of SRs for further scrutiny.

\section{Presentation of results}

Due to the large number of reviews we wanted to included in this overview, and because we wanted to avoid presenting 50 pages of data tables, we took decisions to limit the information presented in tables and figures. Figures 3 to 19 summarise evidence from the 83 included reviews.

We grouped SRs specifically targeting preterm birth prevention (Figures 3 to 10) and SRs targeting either diabetes or other problems women might face during pregnancy (Figures 11 to 19). Interventions targeting PTB had this indication stated in the SR title or had PTB as a primary review outcome. We also grouped SRs according to intervention type: device, health systems, lifestyle, medicines, multiple interventions, nutrition, screening, psychosocial, and surgical. In all figures below 'Not reported' means that no trial included in the SR reported data for that particular outcome. 'Not a review outcome' means that the SR did not search eligible trials for that outcome because the outcome was not a review priority. Finally, 'No trials' indicates an empty SR.

\section{Results from all SRs}

We included 83 SRs; seven of these were empty reviews (i.e. included no randomised trials), and a further six SRs had no trial data for either of the overview outcomes of PD or PTB. We categorised available outcome effect estimates as of clear benefit, clear harm, clear evidence of no effect or equivalence, possible benefit, possible harm or unknown benefit or harm as explained in Figure 2 .
The figures of graphic icons are not intended to replace close inspection of individual SRs and the often complicated results found there. Rather, our overview intends to assess the quality of evidence for the key outcomes of preterm birth and perinatal death and to signpost readers interested in specific effect estimates to full SRs. Individual SRs report complete details of the relevant clinical populations and geographic settings, trials' risks of bias, and forest plots indicating the relative contribution of individual trials to a pooled estimate. The Characteristics of included studies table (Table 1) may be read in tandem with the figures of graphic icons; this table includes information on the review search date, the number of clinical trials and pregnant women included in the review, overview outcome measures reported and review authors' conclusions.

Not all included SRs reported on both overview outcomes of preterm birth and perinatal death. For some SRs, our figures summarise effect estimates for more than one comparison. No SR reported spontaneous PTB as distinct from PTB, and we expect most results below represent a mix of spontaneous and providerinitiated PTB.

We report results for preterm birth and perinatal death separately. For preterm birth, we summarised any outcome measure of preterm birth (any gestational age (GA) value) and followed individual SR decisions to prioritise specific time points (e.g. if we found PTB $<34$ weeks' gestation in the 'Summary of findings' table and other time points in the text, we took the measure used in the 'Summary of findings' table). We note that perinatal death as reported in SRs refers to stillbirths and neonatal deaths counted together.

\section{Results from reviews of interventions targeting PTB prevention}

Thirty-six SRs summarised evidence for interventions with the aim of preterm birth prevention. The following figures present graphic icons assigned to SR evidence for the outcomes of preterm birth and perinatal death: Figure 3 Device; Figure 4 Health systems; Figure 5 Lifestyle; Figure 6 Medicines; Figure 7 Nutrition; Figure 8 Psychosocial; Figure 9 Screening; and Figure 10 Surgical. Because these interventions were intended as preterm birth prevention, we include details of any preterm birth-related risk factors in the target populations.

Figure 3.

\begin{tabular}{|c|c|c|c|c|}
\hline $\begin{array}{l}\text { Device interventions for } \\
\text { preterm birth prevention }\end{array}$ & Risk factor & $\begin{array}{l}\text { Main } \\
\text { Comparison }\end{array}$ & $\begin{array}{l}\text { Perinatal } \\
\text { death }\end{array}$ & $\begin{array}{l}\text { Preterm } \\
\text { birth }\end{array}$ \\
\hline $\begin{array}{l}\text { Home uterine monitoring } \\
\text { for detecting preterm } \\
\text { labour (Urquhart 2017) }\end{array}$ & $\begin{array}{l}\text { Women considered } \\
\text { to be of high risk of } \\
\text { PTB for any reason } \\
\text { including multiple } \\
\text { pregnancy }\end{array}$ & $\begin{array}{l}\text { Home uterine } \\
\text { monitoring vs } \\
\text { standard care }\end{array}$ & & \\
\hline
\end{tabular}


Figure 4.

\begin{tabular}{|c|c|c|c|c|}
\hline $\begin{array}{l}\text { Health systems } \\
\text { interventions for preterm } \\
\text { birth prevention }\end{array}$ & Risk factor & $\begin{array}{l}\text { Main } \\
\text { comparison }\end{array}$ & $\begin{array}{l}\text { Perinatal } \\
\text { death }\end{array}$ & $\begin{array}{l}\text { Preterm } \\
\text { birth }\end{array}$ \\
\hline $\begin{array}{l}\text { Alternative versus } \\
\text { standard packages of } \\
\text { antenatal care for low-risk } \\
\text { pregnancy (Dowswell } \\
\text { 2015) }\end{array}$ & $\begin{array}{l}\text { Women at low risk } \\
\text { of developing } \\
\text { pregnancy or labour } \\
\text { complications }\end{array}$ & $\begin{array}{l}\text { Reduced } \\
\text { visits vs } \\
\text { standard } \\
\text { antenatal } \\
\text { care }\end{array}$ & & \\
\hline $\begin{array}{l}\text { Group versus conventional } \\
\text { antenatal care for women } \\
\text { (Catling 2015) }\end{array}$ & All pregnant women & $\begin{array}{l}\text { Group vs } \\
\text { individual } \\
\text { antenatal } \\
\text { care }\end{array}$ & & \\
\hline $\begin{array}{l}\text { Incentives for increasing } \\
\text { prenatal care use by } \\
\text { women in order to } \\
\text { improve maternal and } \\
\text { neonatal outcomes (Till } \\
\text { 2015) }\end{array}$ & All pregnant women & $\begin{array}{l}\text { Incentive vs } \\
\text { no } \\
\text { incentive }\end{array}$ & $\begin{array}{l}\text { Not } \\
\text { reported }\end{array}$ & $\begin{array}{l}\text { Not } \\
\text { reported }\end{array}$ \\
\hline $\begin{array}{l}\text { Midwife-led continuity } \\
\text { models versus other } \\
\text { models of care for } \\
\text { childbearing women } \\
\text { (Sandall 2016) }\end{array}$ & All pregnant women & $\begin{array}{l}\text { Midwife- } \\
\text { led vs other } \\
\text { models of } \\
\text { care }\end{array}$ & & \\
\hline $\begin{array}{l}\text { Specialised antenatal } \\
\text { clinics for women with a } \\
\text { multiple pregnancy for } \\
\text { improving maternal and } \\
\text { infant outcomes (Dodd } \\
\text { 2015b) }\end{array}$ & Multiple pregnancy & $\begin{array}{l}\text { Specialised } \\
\text { antenatal } \\
\text { clinic vs } \\
\text { standard } \\
\text { antenatal } \\
\text { care }\end{array}$ & & $\begin{array}{l}\text { Not } \\
\text { reported }\end{array}$ \\
\hline
\end{tabular}


Figure 5.

Lifestyle interventions for preterm birth prevention Bed rest in singleton pregnancies for preventing preterm birth (Sosa 2015)

Bed rest with and without hospitalisation in multiple pregnancy for improving perinatal outcomes (da Silva Lopes 2017)

Effects of restricted caffeine intake by mother on fetal, neonatal and pregnancy outcomes (Jahanfar 2015)

Nutritional advice for improving outcomes in multiple pregnancies (Bricker 2015b)

\section{Risk factor}

Women at high risk of PTB due to prior PTB; threatened PTL; positive screening test (fetal fibronectin or short cervical length on ultrasound); low pre-pregnancy BMI; women identified through risk scoring systems

Women without PPROM or multiple pregnancy

Multiple pregnancy

All pregnant women

Multiple pregnancy

\begin{tabular}{l|l|l} 
Main & Perinatal & Preterm \\
comparison & death & birth
\end{tabular}

Bed rest vs placebo or no treatment

Not

reported

Strict bed rest in hospital vs no activity restriction at

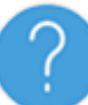
home Cafeinated vs decaffeinated coffee

Not reported
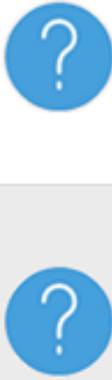

No trials 
Figure 6.

\begin{tabular}{|c|c|c|c|c|}
\hline $\begin{array}{l}\text { Medicines for preterm } \\
\text { birth prevention }\end{array}$ & Risk factor & $\begin{array}{l}\text { Main } \\
\text { comparison }\end{array}$ & $\begin{array}{l}\text { Perinatal } \\
\text { death }\end{array}$ & $\begin{array}{l}\text { Preterm } \\
\text { birth }\end{array}$ \\
\hline $\begin{array}{l}\text { Antibiotic prophylaxis } \\
\text { during the second and } \\
\text { third trimester to reduce } \\
\text { adverse pregnancy } \\
\text { outcomes and morbidity } \\
\text { (Thinkhamrop 2015) }\end{array}$ & $\begin{array}{l}\text { All pregnant } \\
\text { women and women } \\
\text { with a history of } \\
\text { PTB or LBW infant, } \\
\text { BV in the current } \\
\text { pregnancy, or pre- } \\
\text { pregnancy weight } \\
\text { of }<50 \mathrm{~kg}\end{array}$ & $\begin{array}{l}\text { Prophylactic } \\
\text { antibiotics vs } \\
\text { placebo }\end{array}$ & & \\
\hline $\begin{array}{l}\text { Antibiotics for } \\
\text { asymptomatic bacteriuria } \\
\text { in pregnancy ( } S \text { maill 2015) }\end{array}$ & $\begin{array}{l}\text { Bacteriuria } \\
\text { (asymptomatic) }\end{array}$ & $\begin{array}{l}\text { Antibiotic vs } \\
\text { no treatment }\end{array}$ & $\begin{array}{l}\text { Not } \\
\text { reported }\end{array}$ & \\
\hline $\begin{array}{l}\text { Duration of treatment for } \\
\text { asymptomatic bacteriuria } \\
\text { during pregnancy } \\
\text { (Widmer 2015) }\end{array}$ & $\begin{array}{l}\text { Bacteriuria } \\
\text { (asymptomatic) }\end{array}$ & $\begin{array}{l}\text { Single dose vs } \\
\text { short course } \\
\text { (4-7 days) }\end{array}$ & $\begin{array}{l}\text { Not } \\
\text { reported }\end{array}$ & \\
\hline $\begin{array}{l}\text { Interventions for treating } \\
\text { genital Chlamydia } \\
\text { trachomatis infection in } \\
\text { pregnancy (Cluver 2017) }\end{array}$ & $\begin{array}{l}\text { Chlamydia } \\
\text { trachomatis } \\
\text { infection }\end{array}$ & $\begin{array}{l}\text { Erythromycin } \\
\text { vs placebo }\end{array}$ & & \\
\hline $\begin{array}{l}\text { Prenatal administration of } \\
\text { progestogens for } \\
\text { preventing spontaneous } \\
\text { preterm birth in women } \\
\text { with a multiple pregnancy } \\
\text { (Dodd } 2017 \text { ) }\end{array}$ & Multiple pregnancy & $\begin{array}{l}\text { Intra-muscular } \\
\text { Progesterone } \\
\text { vs placebo } \\
\text { Vaginal } \\
\text { Progesterone } \\
\text { vs placebo }\end{array}$ & & \\
\hline $\begin{array}{l}\text { Prophylactic oral } \\
\text { betamimetics for reducing } \\
\text { preterm birth in women } \\
\text { with a twin pregnancy }\end{array}$ & Multiple pregnancy & $\begin{array}{l}\text { Oral } \\
\text { betamimetic vs } \\
\text { placebo }\end{array}$ & & \\
\hline
\end{tabular}

(Yamasmit 2015) 
Figure 7.

\begin{tabular}{|c|c|c|c|c|}
\hline $\begin{array}{l}\text { Nutrition interventions for } \\
\text { preterm birth prevention }\end{array}$ & Risk factor & Main comparison & $\begin{array}{l}\text { Perinatal } \\
\text { death }\end{array}$ & $\begin{array}{l}\text { Preterm } \\
\text { birth }\end{array}$ \\
\hline $\begin{array}{l}\text { Calcium supplementation (other } \\
\text { than for preventing or treating } \\
\text { hypertension) for improving } \\
\text { pregnancy and infant outcomes } \\
\text { (Buppasiri 2015) }\end{array}$ & $\begin{array}{l}\text { All pregnant } \\
\text { women }\end{array}$ & $\begin{array}{l}\text { Calcium } \\
\text { supplementation vs } \\
\text { placebo or no } \\
\text { treatment }\end{array}$ & & \\
\hline $\begin{array}{l}\text { Daily oral iron supplementation } \\
\text { during pregnancy (Peña-Rosas } \\
\text { 2015a) }\end{array}$ & $\begin{array}{l}\text { All pregnant } \\
\text { women }\end{array}$ & $\begin{array}{l}\text { Any iron vs } \\
\text { supplements } \\
\text { without iron or no } \\
\text { treatment/placebo }\end{array}$ & & \\
\hline $\begin{array}{l}\text { Intermittent oral iron } \\
\text { supplementation during } \\
\text { pregnancy (Peña-Rosas 2015b) }\end{array}$ & $\begin{array}{l}\text { Pregnant } \\
\text { women without } \\
\text { HIV or TB }\end{array}$ & $\begin{array}{l}\text { Intermittent vs daily } \\
\text { regimen }\end{array}$ & & \\
\hline $\begin{array}{l}\text { lodine supplementation for } \\
\text { women during the } \\
\text { preconception, pregnancy and } \\
\text { postpartum period (Harding } \\
\text { 2017) }\end{array}$ & $\begin{array}{l}\text { Pregnant } \\
\text { women without } \\
\text { thyroid } \\
\text { disorders, HIV, } \\
\text { or TB }\end{array}$ & $\begin{array}{l}\text { Any iodine vs no } \\
\text { iodine or no } \\
\text { treatment }\end{array}$ & & \\
\hline $\begin{array}{l}\text { Multiple-micronutrient } \\
\text { supplementation for women } \\
\text { during pregnancy (Haider 2017) }\end{array}$ & $\begin{array}{l}\text { Pregnant } \\
\text { women without } \\
\text { HIV }\end{array}$ & $\begin{array}{l}\text { MMN with iron and } \\
\text { folic acid vs iron } \\
\text { with or without folic } \\
\text { acid }\end{array}$ & & \\
\hline $\begin{array}{l}\text { Pyridoxine (vitamin B6) } \\
\text { supplementation during } \\
\text { pregnancy or labour for maternal } \\
\text { and neonatal outcomes (Salam } \\
2015 \text { c) }\end{array}$ & $\begin{array}{l}\text { All pregnant } \\
\text { women }\end{array}$ & $\begin{array}{l}\text { Pyridoxine B6 vs } \\
\text { control }\end{array}$ & $\begin{array}{l}\text { Not a } \\
\text { review } \\
\text { outcome }\end{array}$ & $\begin{array}{l}\text { Not } \\
\text { reported }\end{array}$ \\
\hline $\begin{array}{l}\text { Vitamin C supplementation in } \\
\text { pregnancy (Rumbold 2015a) }\end{array}$ & $\begin{array}{l}\text { All pregnant } \\
\text { women }\end{array}$ & $\begin{array}{l}\text { Vitamin C alone or } \\
\text { with other } \\
\text { supplements vs } \\
\text { placebo or control }\end{array}$ & & \\
\hline $\begin{array}{l}\text { Vitamin D supplementation for } \\
\text { women during pregnancy (De- } \\
\text { Regil 2016) }\end{array}$ & $\begin{array}{l}\text { Pregnant } \\
\text { women without } \\
\text { pre-existing } \\
\text { conditions (i.e. } \\
\text { diabetes) }\end{array}$ & $\begin{array}{l}\text { Vitamin D alone vs } \\
\text { placebo } \\
\text { Vitamin D, calcium } \\
\text { and other vs other }\end{array}$ & & \\
\hline $\begin{array}{l}\text { Vitamin E supplementation in } \\
\text { pregnancy (Rumbold 2015b) }\end{array}$ & $\begin{array}{l}\text { All pregnant } \\
\text { women }\end{array}$ & $\begin{array}{l}\text { Vitamin E vs } \\
\text { placebo, no } \\
\text { treatment or other } \\
\text { supplements }\end{array}$ & & \\
\hline Zinc supplementation for & Pregnant & Zinc vs no zinc & 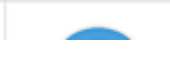 & \\
\hline
\end{tabular}


Figure 7. (Continued)

Zinc supplementation for improving pregnancy and infant outcome (Ota 2015a)
Pregnant

women without

systemic illness suppiements

Zinc vs no zinc

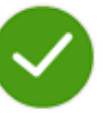

Figure 8.

\begin{abstract}
Psychosocial interventions for preterm birth prevention

Psychosocial interventions for pregnant women in outpatient illicit drug treatment programs compared to other interventions (Terplan 2015)
\end{abstract}

Risk factor
Women in illicit
drug treatment
programmes for
any substance
abuse or drug
dependency
including
methadone

\begin{tabular}{l|l|l|}
$\begin{array}{l}\text { Main Comparison } \\
\text { Motivational- } \\
\text { interviewing based } \\
\text { or contingency- } \\
\text { management based } \\
\text { interventions vs } \\
\text { usual care }\end{array}$ & $\begin{array}{l}\text { Perinatal } \\
\text { death }\end{array}$ & $\begin{array}{l}\text { Preterm } \\
\text { birth }\end{array}$ \\
\hline & $\begin{array}{l}\text { review } \\
\text { outcome }\end{array}$ \\
\hline & \\
\hline
\end{tabular}


Figure 9.

\begin{tabular}{|c|c|c|c|c|}
\hline $\begin{array}{l}\text { Screening for preterm birth } \\
\text { prevention }\end{array}$ & Risk factor & $\begin{array}{l}\text { Main } \\
\text { comparison }\end{array}$ & $\begin{array}{l}\text { Perinatal } \\
\text { death }\end{array}$ & $\begin{array}{l}\text { Preterm } \\
\text { birth }\end{array}$ \\
\hline $\begin{array}{l}\text { Antenatal lower genital } \\
\text { tract infection screening } \\
\text { and treatment programs for } \\
\text { preventing preterm delivery } \\
\text { (Sangkomkamhang 2015) }\end{array}$ & $\begin{array}{l}\text { Women not in PTL, < } 37 \\
\text { weeks' gestation, no } \\
\text { vaginal bleeding, } \\
\text { asymptomatic of lower } \\
\text { genital tract infection }\end{array}$ & $\begin{array}{l}\text { Lower genital } \\
\text { tract infection } \\
\text { screening vs } \\
\text { no screening }\end{array}$ & $\begin{array}{l}\text { Not } \\
\text { reported }\end{array}$ & \\
\hline $\begin{array}{l}\text { Risk-scoring systems for } \\
\text { predicting preterm birth } \\
\text { with the aim of reducing } \\
\text { associated adverse } \\
\text { outcomes (Davey 2015) }\end{array}$ & $\begin{array}{l}\text { Women not in PTL, <37 } \\
\text { week's gestation, } \\
\text { regardless of medical } \\
\text { history or other risk } \\
\text { factors. Multiple } \\
\text { pregnancy included. }\end{array}$ & No trials & & \\
\hline $\begin{array}{l}\text { Routine ultrasound in late } \\
\text { pregnancy (after } 24 \text { weeks' } \\
\text { gestation) (Bricker 2015a) }\end{array}$ & $\begin{array}{l}\text { Women after } 24 \text { weeks' } \\
\text { gestation in both } \\
\text { unselected and } \\
\text { designated low-risk } \\
\text { populations }\end{array}$ & $\begin{array}{l}\text { Routine } \\
\text { ultrasound > } \\
24 \text { weeks vs } \\
\text { no/concealed/ } \\
\text { selective } \\
\text { ultrasound }\end{array}$ & & \\
\hline $\begin{array}{l}\text { Screening and subsequent } \\
\text { management for thyroid } \\
\text { dysfunction pre-pregnancy } \\
\text { and during pregnancy for } \\
\text { improving maternal and } \\
\text { infant health (Spencer } \\
\text { 2015) }\end{array}$ & $\begin{array}{l}\text { Women before or during } \\
\text { pregnancy without a pre- } \\
\text { existing diagnosis of } \\
\text { thyroid dysfunction. } \\
\text { Single or multiple } \\
\text { pregnancy. }\end{array}$ & $\begin{array}{l}\text { Universal } \\
\text { screening vs } \\
\text { case finding in } \\
\text { pregnancy for } \\
\text { any thyroid } \\
\text { dysfunction }\end{array}$ & & \\
\hline $\begin{array}{l}\text { Screening for genital } \\
\text { chlamydia infection (Low } \\
\text { 2016) }\end{array}$ & $\begin{array}{l}\text { Women over the age of } \\
\text { 13. No specific } \\
\text { pregnancy risk stated. }\end{array}$ & $\begin{array}{l}\text { No trials in } \\
\text { pregnancy }\end{array}$ & & \\
\hline
\end{tabular}


Figure 10.

\section{Surgical interventions for preterm birth prevention Cervical stitch (cerclage) for preventing preterm birth in multiple pregnancy (Rafael 2014) \\ Cervical stitch (cerclage) for preventing preterm birth in singleton pregnancy (Alfirevic 2017a)}

\begin{tabular}{|c|c|c|c|c|}
\hline $\begin{array}{l}\text { Surgical interventions for } \\
\text { preterm birth prevention }\end{array}$ & Risk factor & $\begin{array}{l}\text { Main } \\
\text { comparison }\end{array}$ & $\begin{array}{l}\text { Perinatal } \\
\text { death }\end{array}$ & $\begin{array}{l}\text { Preterm } \\
\text { birth }\end{array}$ \\
\hline $\begin{array}{l}\text { Cervical stitch (cerclage) for } \\
\text { preventing preterm birth in } \\
\text { multiple pregnancy (Rafael 2014) }\end{array}$ & $\begin{array}{l}\text { Multiple } \\
\text { pregnancy }\end{array}$ & $\begin{array}{l}\text { Cerclage vs } \\
\text { no cerclage }\end{array}$ & & \\
\hline $\begin{array}{l}\text { Cervical stitch (cerclage) for } \\
\text { preventing preterm birth in } \\
\text { singleton pregnancy (Alfirevic } \\
\text { 2017a) }\end{array}$ & $\begin{array}{l}\text { Women of high } \\
\text { risk of PTB due } \\
\text { to prior PTB, } \\
\text { prior cervical } \\
\text { surgery or short } \\
\text { cervix on } \\
\text { ultrasound }\end{array}$ & $\begin{array}{l}\text { Cerclage vs } \\
\text { no cerclage }\end{array}$ & & \\
\hline $\begin{array}{l}\text { Reduction of the number of } \\
\text { fetuses for women with a } \\
\text { multiple pregnancy (Dodd 2015a) }\end{array}$ & $\begin{array}{l}\text { Multiple } \\
\text { pregnancy }\end{array}$ & No trials & & \\
\hline $\begin{array}{l}\text { Treating periodontal disease for } \\
\text { preventing adverse birth } \\
\text { outcomes in pregnant women } \\
\text { (Iheozor-Ejiofor 2017) }\end{array}$ & $\begin{array}{l}\text { Women with } \\
\text { periodontal } \\
\text { disease }\end{array}$ & $\begin{array}{l}\text { Periodontal } \\
\text { treatment } \\
\text { vs no } \\
\text { treatment }\end{array}$ & & \\
\hline
\end{tabular}

\begin{tabular}{|c|c|c|c|c|}
\hline $\begin{array}{l}\text { Surgical interventions for } \\
\text { preterm birth prevention }\end{array}$ & Risk factor & $\begin{array}{l}\text { Main } \\
\text { comparison }\end{array}$ & $\begin{array}{l}\text { Perinatal } \\
\text { death }\end{array}$ & $\begin{array}{l}\text { Preterm } \\
\text { birth }\end{array}$ \\
\hline $\begin{array}{l}\text { Cervical stitch (cerclage) for } \\
\text { preventing preterm birth in } \\
\text { multiple pregnancy (Rafael 2014) }\end{array}$ & $\begin{array}{l}\text { Multiple } \\
\text { pregnancy }\end{array}$ & $\begin{array}{l}\text { Cerclage vs } \\
\text { no cerclage }\end{array}$ & & \\
\hline $\begin{array}{l}\text { Cervical stitch (cerclage) for } \\
\text { preventing preterm birth in } \\
\text { singleton pregnancy (Alfirevic } \\
\text { 2017a) }\end{array}$ & $\begin{array}{l}\text { Women of high } \\
\text { risk of PTB due } \\
\text { to prior PTB, } \\
\text { prior cervical } \\
\text { surgery or short } \\
\text { cervix on } \\
\text { ultrasound }\end{array}$ & $\begin{array}{l}\text { Cerclage vs } \\
\text { no cerclage }\end{array}$ & & \\
\hline $\begin{array}{l}\text { Reduction of the number of } \\
\text { fetuses for women with a } \\
\text { multiple pregnancy (Dodd 2015a) }\end{array}$ & $\begin{array}{l}\text { Multiple } \\
\text { pregnancy }\end{array}$ & No trials & & \\
\hline $\begin{array}{l}\text { Treating periodontal disease for } \\
\text { preventing adverse birth } \\
\text { outcomes in pregnant women } \\
\text { (Iheozor-Ejiofor 2017) }\end{array}$ & $\begin{array}{l}\text { Women with } \\
\text { periodontal } \\
\text { disease }\end{array}$ & $\begin{array}{l}\text { Periodontal } \\
\text { treatment } \\
\text { vs no } \\
\text { treatment }\end{array}$ & & \\
\hline
\end{tabular}
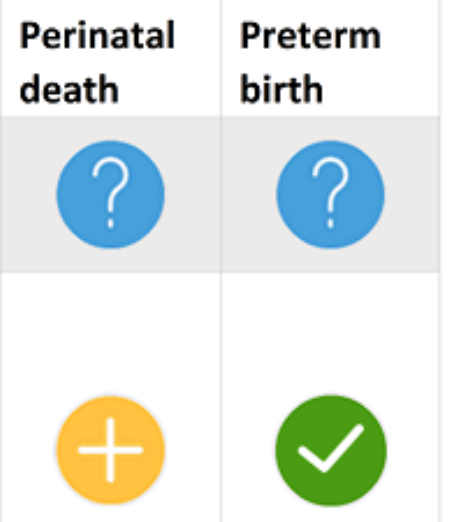

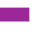

\section{Systematic reviews with no included trials}

The following SRs targeted preterm birth prevention but included no randomised clinical trials: nutritional advice in multiple pregnancy (Bricker 2015b); risk-scoring systems for predicting preterm birth (Davey 2015); screening for genital Chlamydia (Low 2016); and reduction in the number of fetuses in multiple pregnancy (Dodd 2015a).

\section{Impact on preterm birth rates}

\section{Clear evidence of preterm birth reduction}

Clear evidence of benefit signals evidence of GRADE moderate or high quality with a confidence interval that does not cross the line of no effect. We found four SRs reporting clear evidence of benefit to prevent specific populations of pregnant women from giving birth early. These reviews were: midwife-led continuity models of care versus other models of care for all women (Sandall 2016); cervical cerclage for women at high risk of preterm birth and with singleton pregnancy (Alfirevic 2017a); zinc supplementation for pregnant women without systemic illness (Ota 2015a); and antenatal lower genital tract infection screening for pregnant women less than 37 weeks' gestation and without signs of labour, bleeding or infection (Sangkomkamhang 2015).

\section{Clear evidence of harm}

Clear evidence of harm refers to evidence of GRADE moderate or high quality with a confidence interval that does not cross the line of no effect. No included SR reported clear evidence of harm associated with an intervention; that is, we found no intervention that increased women's chances of giving birth preterm.

\section{Clear evidence of no effect or equivalence}

The following SRs reported evidence of GRADE moderate or high quality with a narrow confidence interval crossing the line of no effect. These interventions we categorised to be of clear evidence of no effect or equivalence with a comparator: alternative versus standard packages of antenatal care for women at low risk of developing pregnancy complications (Dowswell 2015); bed rest for women with high risk of preterm birth and singleton pregnancy (Sosa 2015); antibiotic prophylaxis during the second and third trimester for all women or for women with high risk of PTB (Thinkhamrop 2015); calcium supplementation (other than for hypertension) for all pregnant women (Buppasiri 2015); daily oral iron supplementation for all pregnant women (PeñaRosas 2015a); vitamin C supplementation for all pregnant women (Rumbold 2015a); vitamin E supplementation for all pregnant women (Rumbold 2015b); routine ultrasound in later pregnancy for women in unselected or low-risk populations (Bricker 2015a); and screening and subsequent management for thyroid dysfunction for women before or during pregnancy without pre-existing thyroid problems (Spencer 2015).

\section{Possible benefit}

Possible benefit refers to GRADE low-quality evidence with clear benefit (the confidence interval does not cross the line of no effect) or GRADE moderate- or high-quality evidence with wide 
confidence intervals crossing the line of no effect. We found evidence of possible benefit to specific populations of women reported in the following SRs: group antenatal care for all pregnant women (Catling 2015); antibiotics for pregnant women with asymptomatic bacteriuria (Smaill 2015); pharmacological interventions for smoking cessation for pregnant women who smoke (Coleman 2015); and vitamin D supplements alone for women without pre-existing conditions such as diabetes (De-Regil 2016).

\section{Possible harm}

Possible harm refers to GRADE low-quality evidence with clear harm (the confidence interval does not cross the line of no effect) or GRADE moderate- or high-quality evidence with wide confidence intervals crossing the line of no effect. One SR reported possible harm for the effects of intramuscular progesterone for women at high risk of preterm birth with multiple pregnancy (Dodd 2017). Another review found possible harm with vitamin D supplements, calcium and other minerals for pregnant women without preexisting conditions (De-Regil 2016).

\section{Unknown harm or benefit}

Ten SRs reported evidence for the outcome of PTB that we categorised to be of unknown harm or benefit due to effect estimates with wide confidence intervals and evidence of GRADE low or very low quality: home uterine monitoring for high-risk pregnant women (Urquhart 2017); bed rest for women with multiple pregnancy (da Silva Lopes 2017); restricted caffeine intake for all women (Jahanfar 2015); duration of treatment for women with asymptomatic bacteriuria (Widmer 2015); treating genital Chlamydia trachomatis infection in pregnancy (Cluver 2017); vaginal progesterone for women with multiple pregnancy (Dodd 2017); prophylactic oral betamimetics for women with multiple pregnancy (Yamasmit 2015); intermittent oral iron supplementation for women without tuberculosis or HIV (PeñaRosas 2015a); iodine supplementation for pregnant women without thyroid disorders, tuberculosis or HIV (Harding 2017); and multiple micronutrient supplements for pregnant women without HIV (Haider 2017).

\section{Systematic reviews not reporting data for a preterm birth outcome}

The following SRs included trials that did not report data for any preterm birth outcome measure: increasing prenatal care use (Till 2015); specialised antenatal clinics for multiple pregnancy (Dodd 2015b); and pyridoxine (vitamin B6) supplementation (Salam 2015c).

\section{Impact on perinatal death in preterm birth prevention reviews}

\section{Clear evidence of reduction in perinatal deaths}

Two SRs reported evidence of GRADE moderate or high quality with clear evidence of benefit (the confidence interval does not cross the line of no effect): midwife-led continuity models of care for all pregnant women (Sandall 2016); and fetal and umbilical Doppler for pregnant women at high risk (Alfirevic 2017b).

\section{Clear evidence of harm}

No SR reported clear evidence of harm associated with the intervention; no intervention summarised here increased a woman's chance of PD.

\section{Clear evidence of no effect or equivalence}

The following SRs reported GRADE moderate- or high-quality evidence with narrow confidence intervals crossing the line of no effect, suggesting the intervention had no effect or equivalence to a comparator: antibiotic prophylaxis during the second and third trimester for all pregnant women and women at high risk of PTB (Thinkhamrop 2015); calcium supplementation (other than for preventing or treating hypertension) for all pregnant women (Buppasiri 2015); vitamin C for all pregnant women (Rumbold 2015a); vitamin E supplementation for all pregnant women (Rumbold 2015b); routine ultrasound in late pregnancy (after 24 weeks' gestation) for unselected pregnant women and women of low risk (Bricker 2015a); and screening and subsequent management for thyroid dysfunction before or during pregnancy, for women without pre-existing thyroid disorders (Spencer 2015).

\section{Possible benefit}

Possible benefit refers to GRADE low-quality evidence with clear benefit (the confidence interval does not cross the line of no effect) or GRADE moderate- or high-quality evidence with wide confidence intervals crossing the line of no effect. One SR reported possible benefit of cervical stitch (cerclage) for women with singleton pregnancy and high risk of preterm birth (Alfirevic 2017a).

\section{Possible harm}

Possible harm refers to GRADE low-quality evidence with clear harm (the confidence interval does not cross the line of no effect) or GRADE moderate- or high-quality evidence with wide confidence intervals crossing the line of no effect. One SR reported possible harm associated with a reduced schedule of antenatal visits for pregnant women at low risk of pregnancy complications; these pregnant women already received antenatal care in settings with limited resources (Dowswell 2015).

\section{Unknown harm or benefit}

Evidence summarised in the following SRs was of GRADE low or very low quality with a wide confidence interval crossing the line of no effect: home uterine monitoring for high-risk pregnant women (Urquhart 2017); group versus conventional antenatal care for all pregnant women (Catling 2015); specialised antenatal clinics for women with multiple pregnancy (Dodd 2015b); bedrest for women with multiple pregnancy (da Silva Lopes 2017); treating genital Chlamydia trachomatis infection in pregnancy (Cluver 2017); intramuscular progesterone for women with multiple pregnancy (Dodd 2017); vaginal progesterone for women with multiple pregnancy (Dodd 2017); prophylactic oral beta mimetics for women with multiple pregnancy (Yamasmit 2015); daily oral iron supplementation for all pregnant women (Peña-Rosas 2015a); intermittent oral iron supplements for women without tuberculosis or HIV (Peña-Rosas 2015b); iodine supplementation for pregnant women without thyroid disorders, tuberculosis or HIV (Harding 2017); multiple micronutrient supplements for pregnant women without HIV (Haider 2017); vitamin D supplementation for pregnant women without pre-existing conditions such as diabetes (DeRegil 2016); zinc supplementation for pregnant women without systemic illness (Ota 2015a); Cervical stitch (cerclage) for women with multiple pregnancy (Rafael 2014); and Treating periodontal disease (Iheozor-Ejiofor 2017).

Systematic reviews not reporting data for the outcome perinatal death 
The following SRs included trials that did not report the outcome of perinatal death: incentives for increasing prenatal care for all pregnant women (Till 2015); bed rest for women with singleton pregnancy and high risk of PTB (Sosa 2015); restricted caffeine for all pregnant women (Jahanfar 2015); antibiotics for asymptomatic bacteriuria (Smaill 2015); duration of treatment for asymptomatic bacteriuria (Widmer 2015); and antenatal lower genital tract infection screening for women without signs of preterm labour (Sangkomkamhang 2015).

\section{Results from reviews of interventions targeting diabetes or other problems during pregnancy}

Forty-seven SRs summarised relevant evidence for interventions targeting diabetes or other problems women might face during pregnancy. All reviews were included in this overview because they included an eligible population of pregnant women and prespecified or reported data for an overview priority outcome (perinatal death or any measure of preterm birth). The following figures present the graphic icons assigned to SR evidence for these outcomes: Figure 11 Health systems; Figure 12 Lifestyle; Figure 13 Medicines targeting diabetes; Figure 14 Medicines targeting other pregnancy conditions; Figure 15 Multiple interventions; Figure 16 Nutrition; Figure 17 Psychosocial; Figure 18 Screening; Figure 19 Surgical. We found no SRs of Device interventions, so there is no figure for this category.

\section{Figure 11.}

\begin{tabular}{|c|c|c|c|}
\hline Health systems interventions for diabetes & Main comparison & $\begin{array}{l}\text { Perinatal } \\
\text { death }\end{array}$ & $\begin{array}{l}\text { Preterm } \\
\text { birth }\end{array}$ \\
\hline $\begin{array}{l}\text { Interconception care for women with a history of } \\
\text { gestational diabetes for improving maternal and } \\
\text { infant outcomes (Tieu 2017a) }\end{array}$ & No trials & & \\
\hline $\begin{array}{l}\text { Health systems interventions for other pregnancy } \\
\text { conditions }\end{array}$ & Main comparison & $\begin{array}{l}\text { Perinatal } \\
\text { death }\end{array}$ & $\begin{array}{l}\text { Preterm } \\
\text { birth }\end{array}$ \\
\hline $\begin{array}{l}\text { Directed preconception health programs and } \\
\text { interventions for improving pregnancy outcomes } \\
\text { for women who are overweight or obese (Opray } \\
\text { 2015) }\end{array}$ & No trials & & \\
\hline $\begin{array}{l}\text { Health system and community level interventions } \\
\text { for improving antenatal care coverage and health } \\
\text { outcomes (Mbuagbaw 2015) }\end{array}$ & $\begin{array}{l}\text { One intervention vs } \\
\text { none } \\
\text { Combined } \\
\text { intervention vs none }\end{array}$ & & \\
\hline
\end{tabular}


Figure 12.

\section{Lifestyle interventions targeting diabetes}

Diet and exercise interventions for preventing gestational diabetes mellitus

(Bain 2015)

Diet or exercise, or both, for preventing excessive weight gain in pregnancy

(Muktabhant 2015)

Dietary advice interventions in pregnancy for preventing gestational diabetes mellitus (Tieu 2017b)

Different types of dietary advice for women with gestational diabetes mellitus (Han 2017)

Exercise for pregnant women with gestational diabetes for improving maternal and fetal outcomes (Brown 2017b)

Lifestyle interventions for the treatment of women with gestational diabetes (Brown 2017a)

Lifestyle interventions targeting other pregnancy conditions

Antenatal dietary education and supplementation to increase energy and protein intake (Ota 2015b)

Interventions for preventing or reducing domestic violence against pregnant women (Jahanfar 2014)
Main comparison

Combined diet and exercise vs control

\section{All diet and/or exercise} interventions vs standard/other care

Dietary advice interventions vs standard care

\section{Low-moderate GI diet vs} moderate-high GI diet

Energy-restricted diet vs no energy-restricted diet

Exercise vs control

\section{Perinatal Preterm \\ death birth}

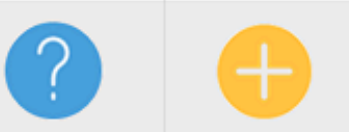

Not

reported

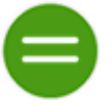

Not

reported

Not

reported
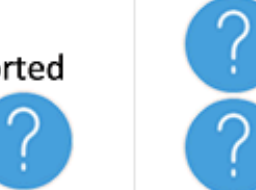
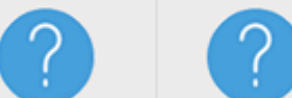

Lifestyle intervention vs usual care or diet alone
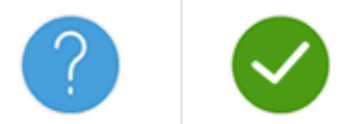

Main comparison

Perinatal

Preterm

Nutritional education vs no

counselling or education

death birth

Any intervention to prevent violence (all interventions) vs standard care

Not reported 
Figure 13.

\section{Medicines}

targeting diabetes

Continuous subcutaneous insulin infusion versus multiple daily injections of insulin for pregnant women with diabetes (Farrar 2016) Different insulin types and regimens for pregnant women with preexisting diabetes (O'Neill 2017) Different intensities of glycaemic control for women with gestational diabetes mellitus (Martis 2016) Different intensities of glycaemic control for pregnant women with pre-existing diabetes (Middleton 2016)

Impact of Haemophilus influenzae type B ( $\mathrm{Hib}$ ) and viral influenza vaccinations in pregnancy for improving maternal, neonatal and infant health outcomes (Salam 2015b)

Oral anti-diabetic agents for women with established diabetes/impaired glucose tolerance or previous gestational diabetes planning pregnancy, or pregnant women with pre-existing diabetes (Tieu 2017c) Oral anti-diabetic pharmacological therapies for the treatment of women with gestational diabetes(Brown 2017c)

Main comparison
Continuous
subcutaneous infusion
vs multiple daily
injections of insulin
Lispro vs regular insulin

\section{Perinatal Preterm death birth}

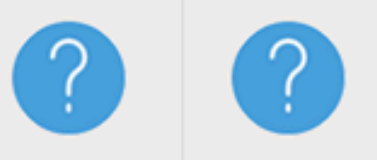

Not reported

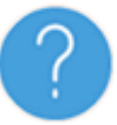

Strict glycaemic control vs Less strict glycaemic control

Not reported

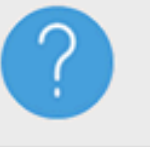

Very tight vs tightmoderate glycaemic control targets

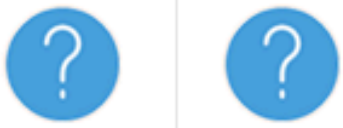

Viral influenza vaccine vs placebo vaccine

Metformin vs insulin

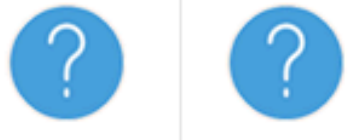

\begin{tabular}{|l|l|l|}
$\begin{array}{l}\text { Oral anti-diabetic } \\
\text { pharmacological } \\
\text { therapies vs placebo }\end{array}$ & $\begin{array}{l}\text { Not } \\
\text { reported }\end{array}$ & $\begin{array}{l}\text { Not } \\
\text { reported }\end{array}$ \\
\hline
\end{tabular}


Figure 14.

\section{Medicines targeting other} pregnancy conditions

Drugs for preventing malaria in pregnant women in endemic areas (Radeva-Petrova 2014)

\section{Effect of administration of} antihelminthics for soil-transmitted helminths during pregnancy (Salam 2015a)

Pharmacological interventions for promoting smoking cessation during pregnancy (Coleman 2015)

\section{Main comparison}

Malaria

chemoprevention (any

regimen) vs placebo or no intervention

Antihelminthics vs

control

Nicotine replacement

therapy vs control

\section{Perinatal Preterm \\ death \\ birth}
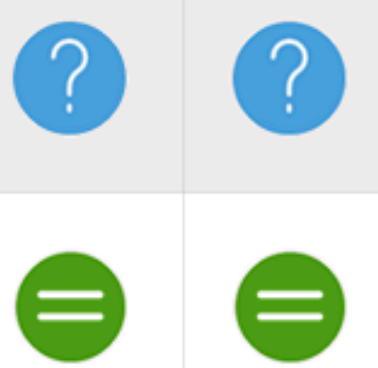
Figure 15.

\begin{tabular}{|c|c|c|c|}
\hline $\begin{array}{l}\text { Multiple interventions targeting } \\
\text { other pregnancy conditions }\end{array}$ & Main comparison & $\begin{array}{l}\text { Perinatal } \\
\text { death }\end{array}$ & $\begin{array}{l}\text { Preterm } \\
\text { birth }\end{array}$ \\
\hline $\begin{array}{l}\text { Interventions for managing asthma } \\
\text { in pregnancy (Bain 2014) }\end{array}$ & Inhaled corticosteroid vs control & & \\
\hline $\begin{array}{l}\text { Interventions for heartburn in } \\
\text { pregnancy (Phupong 2015) }\end{array}$ & $\begin{array}{l}\text { - Drug vs placebo or no treatment } \\
\text { - Drug vs diet/ lifestyle } \\
\text { intervention } \\
\text { - Acupuncture vs no treatment }\end{array}$ & $\begin{array}{l}\text { Not a } \\
\text { review } \\
\text { outcome }\end{array}$ & $\begin{array}{l}\text { Not } \\
\text { reported for } \\
\text { any } \\
\text { comparison }\end{array}$ \\
\hline $\begin{array}{l}\text { Interventions for leg cramps in } \\
\text { pregnancy (Zhou 2015) }\end{array}$ & $\begin{array}{l}\text { Oral Magnesium vs placebo/no } \\
\text { treatment }\end{array}$ & $\begin{array}{l}\text { Not } \\
\text { reported }\end{array}$ & $\begin{array}{l}\text { Not } \\
\text { reported }\end{array}$ \\
\hline $\begin{array}{l}\text { Interventions for treating } \\
\text { hyperemesis gravidarum (Boelig } \\
\text { 2016) }\end{array}$ & $\begin{array}{l}\text { - Acupuncture vs placebo } \\
\text { - Corticosteroid vs promethazine } \\
\text { - Corticosteroid vs placebo }\end{array}$ & $\begin{array}{l}\text { All } \\
\text { comparisons }\end{array}$ & $\begin{array}{l}\text { All } \\
\text { com }\end{array}$ \\
\hline $\begin{array}{l}\text { Interventions for nausea and } \\
\text { vomiting in early pregnancy } \\
\text { (Matthews 2015) }\end{array}$ & $\begin{array}{l}\text { Comparisons not prioritised by } \\
\text { review authors. } \\
\text { - Ginger vs Vitamin B6 }\end{array}$ & $\begin{array}{l}\text { Not } \\
\text { reported }\end{array}$ & \\
\hline $\begin{array}{l}\text { Interventions for preventing } \\
\text { recurrent urinary tract infection } \\
\text { during pregnancy (Schneeberger } \\
\text { 2015) }\end{array}$ & $\begin{array}{l}\text { Nitrofurantoin and close } \\
\text { surveillance vs close surveillance } \\
\text { only }\end{array}$ & $\begin{array}{l}\text { Not } \\
\text { reported }\end{array}$ & \\
\hline $\begin{array}{l}\text { Interventions for varicose veins } \\
\text { and leg oedema in pregnancy } \\
\text { (Smyth 2015) }\end{array}$ & Rutoside vs placebo & $\begin{array}{l}\text { Not } \\
\text { reported }\end{array}$ & $\begin{array}{l}\text { Not } \\
\text { reported }\end{array}$ \\
\hline
\end{tabular}


Figure 16.

\begin{tabular}{|l|l|l|l|}
\hline $\begin{array}{l}\text { Nutrition interventions targeting diabetes } \\
\begin{array}{l}\text { Dietary supplementation with myo-inositol in } \\
\text { women during pregnancy for treating }\end{array}\end{array}$ & Main comparison & $\begin{array}{l}\text { Perinatal } \\
\text { death }\end{array}$ & $\begin{array}{l}\text { Preterm } \\
\text { birth }\end{array}$ \\
\hline $\begin{array}{l}\text { gestational diabetes (Brown 2016) } \\
\text { Nutrition interventions targeting other } \\
\text { pregnancy conditions }\end{array}$ & Main comparison & $\begin{array}{l}\text { Perinatal } \\
\text { reported }\end{array}$ & $\begin{array}{l}\text { Preterm } \\
\text { birth }\end{array}$ \\
\hline $\begin{array}{l}\text { Calcium supplementation commencing } \\
\text { before or early in pregnancy, or food } \\
\text { fortification with calcium, for preventing } \\
\text { hypertensive disorders of pregnancy } \\
\text { (Hofmeyr 2017) }\end{array}$ & $\begin{array}{l}\text { Calcium plus other } \\
\text { supplements vs placebo }\end{array}$ & & \\
\hline $\begin{array}{l}\text { Effects and safety of periconceptional oral } \\
\text { folate supplementation for preventing birth } \\
\text { defects (De-Regil 2015) }\end{array}$ & $\begin{array}{l}\text { Folate vs no treatment, } \\
\text { placebo or MMN without } \\
\text { folate }\end{array}$ & $\begin{array}{l}\text { Not } \\
\text { reported }\end{array}$ & \\
\hline $\begin{array}{l}\text { Multiple micronutrient powders for home } \\
\text { (point-of-use) fortification of foods in } \\
\text { pregnant women (Suchdev 2015) }\end{array}$ & $\begin{array}{l}\text { MMN powders vs iron and } \\
\text { folic acid supplements }\end{array}$ & $\begin{array}{l}\text { Not } \\
\text { reported }\end{array}$ & $\begin{array}{l}\text { Not } \\
\text { reported }\end{array}$ \\
\hline $\begin{array}{l}\text { Vitamin A supplements for reducing mother- } \\
\text { to-child HIV transmission (Wiysonge 2017) }\end{array}$ & $\begin{array}{l}\text { Vitamin A vs placebo or no } \\
\text { treatment }\end{array}$ & $\begin{array}{l}\text { Not a } \\
\text { review } \\
\text { outcome }\end{array}$ \\
\hline $\begin{array}{l}\text { Vitamin A supplementation during pregnancy } \\
\text { for maternal and newborn outcomes } \\
\text { (McCauley 2015) }\end{array}$ & $\begin{array}{l}\text { Vitamin A alone vs placebo } \\
\text { or no treatment }\end{array}$ & \\
\hline
\end{tabular}

Figure 17.

\begin{tabular}{|l|l|l|l|}
\hline $\begin{array}{l}\text { Psychosocial interventions targeting } \\
\text { other pregnancy conditions }\end{array}$ & Main comparison & $\begin{array}{l}\text { Perinatal } \\
\text { death }\end{array}$ & $\begin{array}{l}\text { Preterm } \\
\text { birth }\end{array}$ \\
\hline $\begin{array}{l}\text { Psychosocial interventions for } \\
\text { supporting women to stop smoking in } \\
\text { pregnancy (Chamberlain 2017) }\end{array}$ & $\begin{array}{l}\text { Any psychosocial } \\
\text { intervention vs control }\end{array}$ & $?$ \\
\hline
\end{tabular}


Figure 18.

\section{Screening for diabetes}

Different methods and settings for glucose monitoring for gestational diabetes during pregnancy (Raman 2017)

Different strategies for diagnosing gestational diabetes to improve maternal and infant health (Farrar 2017)

Screening for gestational diabetes mellitus based on different risk profiles and settings for improving maternal and infant health (Tieu 2017d)

Techniques of monitoring blood glucose during pregnancy for women with pre-existing diabetes (Moy 2017)
Main comparison

Telemedicine versus standard care

Self-monitoring versus periodic monitoring

Glucose monomer vs glucose polymer

Universal vs risk factor screening

Primary care vs secondary care screening

Self-monitoring vs standard care

Self-monitoring vs hospitalisation
Perinatal Preterm death birth

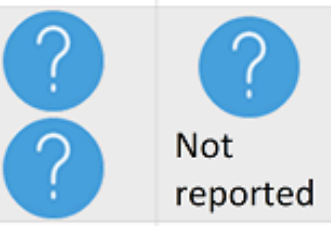

Not

reported

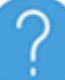

\section{Screening for other pregnancy} conditions

Antenatal cardiotocography for fetal assessment (Grivell 2015)

Main comparison

Not reported

Traditional CTG vs no CTG

Computerised CTG vs Traditional CTG
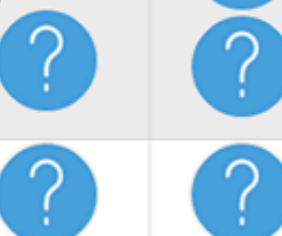

? ?

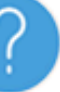

Perinatal

Preterm death birth

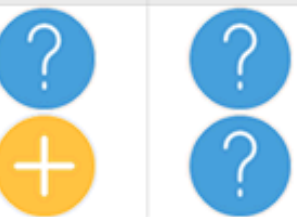

Customised versus population-based growth charts as a screening tool for detecting small for gestational age

No trials infants in low-risk pregnant women (Carberry 2014)

Fetal and umbilical Doppler

Any Doppler vs no Doppler ultrasound in normal pregnancy (Alfirevic 2015)

Fetal and umbilical Doppler ultrasound in high-risk pregnancies (Alfirevic 2017b)

Any Doppler vs no Doppler
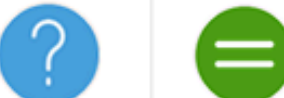

Routine blood cultures in the management of pyelonephritis in pregnancy for improving outcomes

No trials (Gomi 2015) Use of biochemical tests of placental function for improving pregnancy

Tests of placental function vs standard care

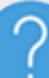
... .......
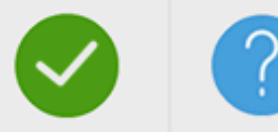
Figure 18. (Continued)

function for improving pregnancy standard care
outcome (Heazell 2015)

Figure 19.

\section{Surgical interventions targeting other pregnancy conditions}

Amnioinfusion for chorioamnionitis

(Hofmeyr 2016)

External cephalic version (ECV) for breech presentation before term (Hutton 2015)

\begin{tabular}{l|l|l} 
Main Comparison & $\begin{array}{l}\text { Perinatal } \\
\text { death }\end{array}$ & $\begin{array}{l}\text { Preterm } \\
\text { birth }\end{array}$ \\
$\begin{array}{l}\text { Transcervical amnioinfusion } \\
\text { vs no amnioinfusion }\end{array}$ \\
$\begin{array}{l}\text { ECV before term vs ECV at } \\
\text { term }\end{array}$
\end{tabular}

For the sake of brevity, below we do not summarise individual SRs with evidence of unknown harm or benefit for overview outcomes as symbolised by the blue question mark graphic - this task would reiterate what is already apparent in the figures - i.e. there are many interventions for which we have little trial evidence summarised in SRs. Neither do we list the SRs that did not report outcome data this information may also be found directly in the figures. As above, we direct readers to consider evidence presented in the figures together with the 'Characteristics of included systematic reviews' table (Figure 1).

\section{Systematic reviews with no included trials}

The following SRs targeted diabetes or other problems during pregnancy and prespecified an overview priority outcome but included no randomised clinical trials: customised versus population-based growth charts as a screening tool for detecting small for gestational age babies (Carberry 2014); routine blood cultures for the management of pyelonephritis in pregnancy (Gomi 2015); and directed preconception health programs and interventions for women who are overweight or obese (Opray 2015).

\section{Impact on preterm birth}

\section{Clear evidence of benefit}

One SR reported evidence of GRADE moderate or high quality with clear evidence of benefit (the confidence interval does not cross the line of no effect): lifestyle interventions for the treatment of women with gestational diabetes (Brown 2017a).

\section{Clear evidence of harm}

No SR reported clear evidence of harm associated with the intervention; no intervention summarised here increased a woman's chance of PTB.

\section{Clear evidence of no effect or equivalence}

The following SRs reported GRADE moderate- or high-quality evidence with narrow confidence intervals crossing the line of no effect, suggesting the intervention had no effect or equivalence to a comparator: combined health systems interventions to improve antenatal care uptake (Mbuagbaw 2015); diet or exercise or both for preventing excessive weight gain in pregnancy (Muktabhant 2015); vitamin A supplementation (McCauley 2015); antihelminthics during pregnancy (Salam 2015a); psychosocial interventions to stop smoking in pregnancy (Chamberlain 2017); and fetal and umbilical Doppler ultrasound in normal pregnancy (Alfirevic 2015).

\section{Possible benefit}

Possible benefit refers to GRADE low-quality evidence with clear benefit (the confidence interval does not cross the line of no effect) or GRADE moderate- or high-quality evidence with wide confidence intervals crossing the line of no effect. Three SRs reported such evidence for: diet and exercise interventions for preventing gestational diabetes mellitus (Bain 2015); antenatal dietary education and supplementation to increase energy and protein intake (Ota 2015b); and pharmacological interventions for promoting smoking cessation during pregnancy (Coleman 2015).

\section{Possible harm}

Possible harm refers to GRADE low-quality evidence with clear harm (the confidence interval does not cross the line of no effect) or GRADE moderate- or high-quality evidence with wide confidence intervals crossing the line of no effect. One SR reported such evidence for the effects of external cephalic version for breech presentation before term (Hutton 2015).

\section{Unknown harm or benefit}

Evidence summarised in many SRs was of GRADE low or very low quality with a wide confidence interval crossing the line of no effect (see Figures 11 to 19).

\section{Impact on perinatal death}

\section{Clear evidence of benefit}

Two SRs reported evidence of GRADE moderate- or high-quality with clear evidence of benefit (the confidence interval does not 
cross the line of no effect): combined health systems interventions to improve antenatal care uptake (Mbuagbaw 2015); and fetal and umbilical Doppler ultrasound in high-risk pregnancy (Alfirevic 2017b).

\section{Clear evidence of harm}

No SR reported clear evidence of harm associated with the intervention; no intervention summarised here increased a woman's chance of PD.

\section{Clear evidence of no effect or equivalence}

The following SRs reported GRADE moderate- or high-quality evidence with narrow confidence intervals crossing the line of no effect, suggesting the intervention had no effect or equivalence to a comparator: combined health systems interventions to improve antenatal care uptake (Mbuagbaw 2015); vitamin A supplementation (McCauley 2015); and antihelminthics during pregnancy (Salam 2015a).

\section{Possible benefit}

Possible benefit refers to GRADE low-quality evidence with clear benefit (the confidence interval does not cross the line of no effect) or GRADE moderate- or high-quality evidence with wide confidence intervals crossing the line of no effect. One SR reported such evidence for computerised cardiotocography in the SR Antenatal cardiotocography for fetal assessment (Grivell 2015).

\section{Possible harm}

Possible harm refers to GRADE low-quality evidence with clear harm (the confidence interval does not cross the line of no effect) or GRADE moderate- or high-quality evidence with wide confidence intervals crossing the line of no effect. No SR reported such evidence.

\section{Unknown harm or benefit}

Evidence summarised in many SRs was of GRADE low or very low quality with a wide confidence interval crossing the line of no effect (see Figures 11 to 19).

\section{Network meta-analysis}

We found no eligible Cochrane Reviews with network metaanalyses (NMA) for inclusion in this overview. If in future updates of the overview we identify relevant reviews, we will apply the methodologies outlined in our protocol to pilot GRADE for important network comparisons and outcomes and to present key network results visually.

\section{Interactive 'Summary of findings' tables}

We did not pilot an interactive 'Summary of findings' table for this version of the overview, but we aim to pilot ideas for presenting layered data tables in online versions of the overview for the next update.

\section{DISCUSSION}

There is little consensus or guidance on the appropriate rationale, methodology or outputs for overviews of systematic reviews (SRs (Ballard 2017; Pieper 2012; Pollock 2016). We have summarised the evidence from relevant Cochrane Reviews using graphic icons to communicate both our confidence in, and the relative effectiveness of diverse interventions with possible impact on preterm birth (PTB). We stress that preterm birth rates reported in included SRs are likely to be a mix of provider-initiated and spontaneous PTB. Perinatal deaths include both stillbirth and neonatal deaths.

\section{Summary of main results}

We found 36 SRs evaluating interventions with PTB prevention as the main focus. Most reviews evaluated interventions related to health systems or screening, or tested the impact of medicines and vitamin supplements.

Four reviews reported clear evidence of benefit, with three relevant to a general pregnant population: midwife-led continuity models of care versus other models of care for all women (Sandall 2016); zinc supplementation for pregnant women without systemic illness (Ota 2015a); and antenatal lower genital tract infection screening for women without signs of preterm labour (Sangkomkamhang 2015). Cervical cerclage was the only surgical intervention found to be of benefit, and is relevant only for women with high risk of PTB and singleton pregnancy (Alfirevic 2017a).

It is worth noting that only midwife-led continuity models of care for all pregnant women (Sandall 2016) showed both reduction in PTB and improvement in perinatal survival. The review authors called for further investigation into how a model of care might prevent PTB. They stressed that this is a complex intervention that requires theoretical modelling of the relationships between processes and outcomes in the trial. Authors cautioned against generalising results to a population with health complications and noted that no included trial took place in a resource-constrained setting.

Authors of the zinc supplementation review qualified their finding of benefit to say that most women in included trials were of low income and may have had poor nutrition (Ota 2015a). Infection screening programs were relevant to a general population of pregnant women (Sangkomkamhang 2015), whilst the benefit of cervical cerclage was only relevant to women at high risk of PTB and singleton pregnancy (Alfirevic 2017a).

No included reviews reported clear evidence of harm, which is very reassuring.

\section{Reviews targeting diabetes or other pregnancy conditions}

Forty-seven included reviews described various interventions targeting diabetes and other conditions in pregnancy. Each specified or reported a PTB outcome, but PTB prevention was not their primary focus. The review by Brown 2017a reported clear benefit of lifestyle interventions for women with gestational diabetes; lifestyle interventions usually involved healthy eating, exercise and self-monitoring of glucose concentrations. Review authors cautioned against generalising this result to women in lowor middle-income countries.

No review targeting diabetes or other health problems during pregnancy reported benefit for both PTB and perinatal death outcomes.

Combined community and health systems interventions to improve antenatal care coverage reduced pregnant women's chances of experiencing perinatal death but had no clear impact on PTB rates (Mbuagbaw 2015). However, this review finding is from 
a single trial investigating augmented care for African-American women with multiple pregnancy risks (Klerman 2001).

Fetal and umbilical Doppler for high-risk pregnant women also showed a reduction in perinatal death but no clear impact on PTB rates (Alfirevic 2017b). As most trials did not have a clearly-defined management protocol that followed abnormal Doppler test, it is difficult to be certain which aspect of subsequent care is the most important - the obvious candidates are better timing of delivery, more appropriate mode of labour (vaginal versus caesarean), and better targeting of antenatal corticosteroids.

Reassuringly, no included reviews reported clear evidence of harm.

\section{Overall completeness and applicability of evidence}

One of our main aims was to highlight strategies to prevent spontaneous preterm birth (SPTB), but none of the included Cochrane Reviews reported SPTB as an outcome distinct from provider-initiated PTB. Despite their focus on PTB prevention, none of the 36 relevant Cochrane Reviews referenced the Global Alliance to Prevent Prematurity and Stillbirth (GAPPS) classification system for PTB (Villar 2012). We would encourage researchers to try to apply these distinctions to enable more nuanced analysis of PTBrelated interventions.

\section{What is missing from the overview?}

We identified 96 SRs that may have been eligible during title assessment but were out-of-date (these are listed in Appendix 2). We regret that we were unable to look further into these SRs.

Our peer reviewers noted that the overview misses out three widely-used interventions to prevent PTB in high-risk pregnant women: cervical pessary, cervical length screening and vaginal progesterone. Certainly there are other interventions that are absent because they we not the subject of a Cochrane Review. For these three specific interventions, we direct readers to several other SRs. Saccone 2017a and Saccone 2017b reviewed trials of cervical pessary for women with singleton and multiple pregnancy and short cervix; pessary did not reduce the rate of SPTB or improve outcomes for the neonate. Berghella 2017 found that cervical length screening reduced women's risk of preterm before 37 weeks' gestation, but led to no improvements in other outcomes for women or neonates. Romero 2018 reported that vaginal progesterone reduced risk of preterm births $<33$ weeks' gestation for women with singleton pregnancy and a short cervix midtrimester; progesterone also improved outcomes for the neonate. We also look forward to the EPPPIC collaboration's individual participant data (IPD) meta-analysis of progestogens (Stewart 2017), and to an updated Cochrane Review on progestogens for singleton pregnancy (Dodd and colleagues, forthcoming). A network meta-analysis comparing progesterone, cerclage and cervical pessary was also relevant; Jarde 2017a found that progesterone (natural and 17-OHPC were both included here) was the most effective for preventing PTB in singleton pregnancy. No intervention was effective to prevent PTB in twin pregnancy (Jarde 2017b).

\section{Quality of the evidence}

We did not conduct formal evaluation of the risks of bias in included SRs with either the AMSTAR or ROBIS tool, due to our confidence in Cochrane Review methodology. All Cochrane Review authors must conduct exhaustive searches for published and unpublished studies; an Information Specialist checks review search results, and editorial topic experts check review authors' eligibility decisions. All review authors apply Cochrane's 'Risk of bias' tool to included trials and report transparent results in tables (Higgins 2011a). From 2016 all Cochrane review authors also assess the quality of review effect estimates using GRADE criteria and report results in 'Summary of findings' tables (Higgins 2018). Cochrane Review methodology alerts readers to potential bias in pooled effect estimates. Our overview further classified review effect estimates to assign a graphic icon and communicate evidence quality (see Figure 2).

To ensure the credible interpretation of SR estimates researchers should consider whether meta-analyses have adequate statistical power (e.g. Schünemann 2013). GRADE criteria consider the imprecision of a pooled estimate, which is related to power, but no SR included in this overview formally reported whether a meta-analysis had adequate data to draw meaningful conclusions. Overview authors may provide such context to improve interpretation of SR evidence.

We also question how far an overview should attempt to interpret SR results in terms of practice recommendations. If individual SRs should not make clinical recommendations (see Higgins 2011b, section 12.7.4 "Common errors in reaching conclusions"), then neither should overviews of reviews, unless overview authors have embarked upon a formal process to vet all available evidence and produce fully-contextualised clinical guidance.

An example of an evidence synthesis project that can endorse specific interventions for clinical practice is a SR of relevant guidelines. Medley 2018 reviewed recommendations in 49 clinical guidelines to identify international consensus for specific interventions to prevent or manage PTB.

We draw attention to a lack of a good evidence base for women with multiple pregnancy. We classified all evidence relevant to multiple pregnancy to be of unknown harm or benefit, and of low- or very-low quality, with the exception of intramuscular progesterone (which may be harmful for women, see Dodd 2017 and Figure 6). We currently have no credible options to offer this population, and this situation must change. Clinicians, researchers and funders must address the lack of high-quality evidence for interventions relevant to women at high risk of preterm birth due to multiple pregnancy.

\section{Potential biases in the overview process}

We followed standard methods to minimise bias. Two overview authors independently conducted eligibility assessment and data extraction, with resolution of conflicts through consultation with a third overview author. None of the overview authors appraised his or her own SR for inclusion; likewise, overview authors did not assess outcome data or assign graphic icons to pooled effect estimates from their own SRs.

We changed our methods from those presented in our protocol to accommodate the large number of included SRs and to communicate the evidence we found. Such deviation from protocol may be considered a source of bias. 


\section{Agreements and disagreements with other studies or reviews}

We found three other publications that assessed SRs relevant to PTB prevention. We found no study that summarised randomised trial evidence for interventions according to a classification scheme similar to ours.

Piso 2014 summarised 56 Cochrane Reviews of interventions to reduce PTB at less than 37 weeks' gestation. Authors found three interventions that increased preterm birth: metronidazole for pregnant women with asymptomatic trichomoniasis (Gülmezoglu 2011); oestrogen supplementation to prevent miscarriage; and vitamin C (Bamigboye 2003). The metronidazole and oestrogen Cochrane Reviews are out of date and are not included in this overview. The result for vitamin $C$ in an updated review included here no longer shows harm but rather shows equivalence of vitamin C with the comparator (Rumbold 2015a, see also Figure 7). Piso cites 12 additional reviews reporting benefit to women, including interventions such as smoking cessation programs and antenatal genital tract infection screening. Our overview does not included the same set of Cochrane Reviews as Piso because some of these Cochrane Reviews are now out-of-date.

Nijman 2016 reviewed interventions to diagnose and treat threatened PTB. The authors found that cervical length measurement combined with fetal fibronectin was the most effective way to identify women who may labour within seven days; corticosteroids improved neonatal outcome; tocolytic therapy should be restricted to 48 hours' use; maintenance tocolysis did not work; magnesium sulphate improved neurological outcomes for the baby; and erythromycin improved neonatal outcomes when women had preterm prelabour rupture of membranes.

Lucaroni 2018 summarised SRs of biomarkers to predict spontaneous PTB and concluded that cervical fetal fibronectin, alpha fetoprotein, C-reactive protein and interleukin 6 each had good diagnostic accuracy to identify women at risk of spontaneous PTB.

One of the important challenges we faced was the appropriate use of user-friendly language bearing in mind that a significant proportion of the readership may not have English as their first language. Jones 2012 categorised interventions for pain during labour with "What works"; "What may work"; and "Insufficient evidence." For Ciapponi 2017, an "effective" intervention had GRADE moderate- or high-certainty evidence showing benefit for a key outcome and no negative effects via other outcomes; similarly, for Shepherd 2017, "effective" meant GRADE high-quality evidence. Farquhar 2018 classified interventions as effective, promising, ineffective, and possibly ineffective or no conclusions, possible due to lack of evidence.

We aimed to create a similarly straight-forward classification scheme able to communicate both review conclusions about an interventions and GRADE criteria and decision-making. We also wanted readers to be able to consider multiple reviews together in the same figure, without encouraging the direct comparison of relative risk estimates across different SRs. To this end, we created the graphic icons to communicate the effects of interventions and our confidence in the estimates. To improve the usefulness of overviews, researchers should agree standard language and investigate new ways to communicate complex SR evidence via graphic or interactive media.

\section{AUTHORS' CONCLUSIONS}

\section{Implications for practice}

No clear evidence of harm from any of the included intervention is reassuring, but the possibility that as many as four may be harmful to women and neonates is a concern. For anyone contemplating their implementation, a careful risk/benefit assessment should be made depending on the setting and available alternative. Reduced antenatal visits may have increased women's risk of perinatal death in settings where pregnant women already received limited antenatal care (Dowswell 2015). Likewise, women's risk of preterm birth (PTB) may have increased with the administration of: intramuscular progesterone for women with multiple pregnancy (Dodd 2017); vitamin D, calcium and other supplements for women without pre-existing conditions (De-Regil 2016); and external cephalic version for women with breech presentation before term (Hutton 2015).

For health systems where the four effective interventions listed in the discussion are not part of clinical care, a rationale for their exclusion should be made available to users. The forums in which such decisions can be justified may not exist, but this can hardly be an excuse today when access to some form of social media is almost universal. The overview summarises no evidence for cervical pessary, cervical length assessment and vaginal progesterone in singleton pregnancy because these Cochrane Reviews were not current. Readers should be aware that these are active areas for PTB research.

The graphic icons assigned to systematic review effect estimates do not constitute clinical guidance or an endorsement of specific interventions for pregnant women. Readers should refer to full systematic reviews for important details on clinical efficacy, target populations, and the geographic setting of clinical trials. Pregnant women and their healthcare providers must carefully consider whether specific strategies to prevent PTB will be of benefit for individual women, or for specific populations of women.

\section{Implications for research}

The difficulty of maintaining timeliness of live systematic reviews in such an active research field as PTB prevention cannot be overstated. Researchers associated with Cochrane have proposed strategies to streamline review production in a series of papers (Elliott 2017). Limiting meta-analyses to priority outcome domains and measures may also make regular updates more feasible and facilitate easier and more accurate data pooling (van't Hooft 2016). Future updates of Cochrane Reviews should apply the Global Alliance to Prevent Prematurity and Stillbirth (GAPPS) classification system or another to enable more nuanced reporting and analysis of PTB (Villar 2012).

Formal consensus work is needed to establish standardised language for overviews and to draw limits for their interpretation of review evidence and its (un)certainty for benefit or harm.

For effective interventions, the underlying mechanism of action on PTB or perinatal death was not always clear. Whilst this should not be an excuse for not implementing interventions demonstrating clear benefit, researchers must be encouraged to find the links 
that would enable further improvements and open other areas of scientific enquiry.

\section{ACKNOWLEDGEMENTS}

As part of the prepublication editorial process, four peers (an editor and three referees who are external to the editorial team), a member of Cochrane Pregnancy and Childbirth's international panel of consumers and the Cochrane Pregnancy and Childbirth's Statistical Adviser commented on the protocol draft. We are grateful for the carefully-considered and helpful comments made during peer review and especially thank Prof. David Haas. The named overview authors alone are responsible for the final content and conclusions of the overview.

This project is supported by the University of Liverpool's HarrisWellbeing of Women Preterm Birth Centre research award (Summer 2015).

This project is supported by the National Institute for Health Research (NIHR), via Cochrane Infrastructure funding to Cochrane Pregnancy and Childbirth. The views and opinions expressed therein are those of the overview authors and do not necessarily reflect those of the Systematic Reviews Programme, the NIHR, the NHS or the UK Department of Health. 


\section{REFERE N C E S}

\section{References to included reviews}

\section{Alfirevic 2015}

Alfirevic Z, Stampalija T, Medley N. Fetal and umbilical Doppler ultrasound in normal pregnancy. Cochrane Database of Systematic Reviews 2015, Issue 4. [DOI: 10.1002/14651858.CD001450.pub4]

\section{Alfirevic 2017a}

Alfirevic Z, Stampalija T, Medley N. Cervical stitch (cerclage) for preventing preterm birth in singleton pregnancy. Cochrane Database of Systematic Reviews 2017, Issue 6. [DOI: 10.1002/14651858.CD008991.pub3]

\section{Alfirevic 2017b}

Alfirevic Z, Stampalija T, Dowswell T. Fetal and umbilical Doppler ultrasound in high-risk pregnancies. Cochrane Database of Systematic Reviews 2017, Issue 6. [DOI: 10.1002/14651858.CD007529.pub4]

\section{Bain 2014}

Bain E, Pierides KL, Clifton VL, Hodyl NA, Stark MJ, Crowther CA, et al. Interventions for managing asthma in pregnancy. Cochrane Database of Systematic Reviews 2014, Issue 10. [DOI: 10.1002/14651858.CD010660.pub2]

\section{Bain 2015}

Bain E, Crane M, Tieu J, Han S, Crowther CA, Middleton P. Diet and exercise interventions for preventing gestational diabetes mellitus. Cochrane Database of Systematic Reviews 2015, Issue 4. [DOI: 10.1002/14651858.CD010443.pub2]

\section{Boelig 2016}

Boelig RC, Barton SJ, Saccone G, Kelly AJ, Edwards SJ, Berghella V. Interventions for treating hyperemesis gravidarum. Cochrane Database of Systematic Reviews 2016, Issue 5. [DOI: 10.1002/14651858.CD010607.pub2]

\section{Bricker 2015a}

Bricker L, Medley N, Pratt JJ. Routine ultrasound in late pregnancy (after 24 weeks' gestation). Cochrane Database of Systematic Reviews 2015, Issue 6. [DOI: 10.1002/14651858.CD001451.pub4]

\section{Bricker 2015b}

Bricker L, Reed K, Wood L, Neilson JP. Nutritional advice for improving outcomes in multiple pregnancies. Cochrane Database of Systematic Reviews 2015, Issue 11. [DOI: 10.1002/14651858.CD008867.pub3]

\section{Brown 2016}

Brown J, Crawford TJ, Alsweiler J, Crowther CA. Dietary supplementation with myo-inositol in women during pregnancy for treating gestational diabetes. Cochrane Database of Systematic Reviews 2016, Issue 9. [DOI: 10.1002/14651858.CD012048.pub2]

\section{Brown 2017a}

Brown J, Alwan NA, West J, Brown S, McKinlay CJ, Farrar D, et al. Lifestyle interventions for the treatment of women with gestational diabetes. Cochrane Database of Systematic Reviews 2017, Issue 5. [DOI: 10.1002/14651858.CD011970.pub2]

\section{Brown 2017b}

Brown J, Ceysens G, Boulvain M. Exercise for pregnant women with gestational diabetes for improving maternal and fetal outcomes. Cochrane Database of Systematic Reviews 2017, Issue 6. [DOI: 10.1002/14651858.CD012202.pub2]

\section{Brown 2017c}

Brown J, Martis R, Hughes B, Rowan J, Crowther CA. Oral antidiabetic pharmacological therapies for the treatment of women with gestational diabetes. Cochrane Database of Systematic Reviews 2017, Issue 1. [DOI: 10.1002/14651858.CD011967.pub2]

\section{Buppasiri 2015}

Buppasiri P, Lumbiganon P, Thinkhamrop J, Ngamjarus C, Laopaiboon M, Medley N. Calcium supplementation (other than for preventing or treating hypertension) for improving pregnancy and infant outcomes. Cochrane Database of Systematic Reviews 2015, Issue 2. [DOI: 10.1002/14651858.CD007079.pub3]

\section{Carberry 2014}

Carberry AE, Gordon A, Bond DM, Hyett J, RaynesGreenow $\mathrm{CH}$, Jeffery HE. Customised versus populationbased growth charts as a screening tool for detecting small for gestational age infants in low-risk pregnant women. Cochrane Database of Systematic Reviews 2014, Issue 5. [DOI: 10.1002/14651858.CD008549.pub3]

\section{Catling 2015}

Catling CJ, Medley N, Foureur M, Ryan C, Leap N, Teate A, et al. Group versus conventional antenatal care for women. Cochrane Database of Systematic Reviews 2015, Issue 2. [DOI: 10.1002/14651858.CD007622.pub3]

\section{Chamberlain 2017}

Chamberlain C, O'Mara-Eves A, Porter J, Coleman T, Perlen SM, Thomas J, et al. Psychosocial interventions for supporting women to stop smoking in pregnancy. Cochrane Database of Systematic Reviews 2017, Issue 2. [DOI: 10.1002/14651858.CD001055.pub5]

\section{Cluver 2017}

Cluver C, Novikova N, Eriksson DO, Bengtsson K, Lingman GK. Interventions for treating genital Chlamydia trachomatis infection in pregnancy. Cochrane Database of Systematic Reviews 2017, Issue 9. [DOI: 10.1002/14651858.CD010485.pub2]

\section{Coleman 2015}

Coleman T, Chamberlain C, Davey M, Cooper SE, Leonardi-Bee J. Pharmacological interventions for promoting smoking cessation during pregnancy. Cochrane Database of Systematic Reviews 2015, Issue 12. [DOI: 10.1002/14651858.CD010078.pub2] 


\section{da Silva Lopes 2017}

da Silva Lopes K, Takemoto Y, Ota E, Tanigaki S, Mori R. Bed rest with and without hospitalisation in multiple pregnancy for improving perinatal outcomes. Cochrane Database of Systematic Reviews 2017, Issue 3. [DOI: 10.1002/14651858.CD012031.pub2]

\section{Davey 2015}

Davey M, Watson L, Rayner JA, Rowlands S. Risk-scoring systems for predicting preterm birth with the aim of reducing associated adverse outcomes. Cochrane Database of Systematic Reviews 2015, Issue 10. [DOI: 10.1002/14651858.CD004902.pub5]

\section{De-Regil 2015}

De-Regil LM, Peña-Rosas JP, Fernández-Gaxiola AC, RaycoSolon P. Effects and safety of periconceptional oral folate supplementation for preventing birth defects. Cochrane Database of Systematic Reviews 2015, Issue 12. [DOI: 10.1002/14651858.CD007950.pub3]

\section{De-Regil 2016}

De-Regil LM, Palacios C, Lombardo LK, Peña-Rosas JP. Vitamin D supplementation for women during pregnancy. Cochrane Database of Systematic Reviews 2016, Issue 1. [DOI: 10.1002/14651858.CD008873.pub3]

\section{Dodd 2015a}

Dodd JM, Dowswell T, Crowther CA. Reduction of the number of fetuses for women with a multiple pregnancy. Cochrane Database of Systematic Reviews 2015, Issue 11. [DOI: 10.1002/14651858.CD003932.pub3]

\section{Dodd 2015b}

Dodd JM, Dowswell T, Crowther CA. Specialised antenatal clinics for women with a multiple pregnancy for improving maternal and infant outcomes. Cochrane Database of Systematic Reviews 2015, Issue 11. [DOI: 10.1002/14651858.CD005300.pub4]

\section{Dodd 2017}

Dodd JM, Grivell RM, Obrien CM, Dowswell T, Deussen AR. Prenatal administration of progestogens for preventing spontaneous preterm birth in women with a multiple pregnancy. Cochrane Database of Systematic Reviews 2017 Issue 10. [DOI: 10.1002/14651858.CD012024.pub2]

\section{Dowswell 2015}

Dowswell T, Carroli G, Duley L, Gates S, Gülmezoglu AM, Khan-Neelofur D, et al. Alternative versus standard packages of antenatal care for low-risk pregnancy. Cochrane Database of Systematic Reviews 2015, Issue 7. [DOI: 10.1002/14651858.CD000934.pub3]

\section{Farrar 2016}

Farrar D, Tuffnell DJ, West J, West HM. Continuous subcutaneous insulin infusion versus multiple daily injections of insulin for pregnant women with diabetes. Cochrane Database of Systematic Reviews 2016, Issue 6. [DOI: 10.1002/14651858.CD005542.pub3]

\section{Farrar 2017}

Farrar D, Duley L, Dowswell T, Lawlor DA. Different strategies for diagnosing gestational diabetes to improve maternal and infant health. Cochrane Database of Systematic Reviews 2017, Issue 8. [DOI: 10.1002/14651858.CD007122.pub4]

\section{Gomi 2015}

Gomi H, Goto Y, Laopaiboon M, Usui R, Mori R. Routine blood cultures in the management of pyelonephritis in pregnancy for improving outcomes. Cochrane Database of Systematic Reviews 2015, Issue 2. [DOI: 10.1002/14651858.CD009216.pub2]

\section{Grivell 2015}

Grivell RM, Alfirevic Z, Gyte GML, Devane D. Antenatal cardiotocography for fetal assessment. Cochrane Database of Systematic Reviews 2015, Issue 9. [DOI: 10.1002/14651858.CD007863.pub4]

\section{Haider 2017}

Haider BA, Bhutta ZA. Multiple-micronutrient supplementation for women during pregnancy. Cochrane Database of Systematic Reviews 2017, Issue 4. [DOI: 10.1002/14651858.CD004905.pub5]

\section{Han 2017}

Han S, Middleton P, Shepherd E, Van Ryswyk E, Crowther CA. Different types of dietary advice for women with gestational diabetes mellitus. Cochrane Database of Systematic Reviews 2017, Issue 2. [DOI: 10.1002/14651858.CD009275.pub3]

\section{Harding 2017}

Harding KB, Peña-Rosas JP, Webster AC, Yap CM, Payne BA, Ota $\mathrm{E}$, et al. lodine supplementation for women during the preconception, pregnancy and postpartum period. Cochrane Database of Systematic Reviews 2017, Issue 3. [DOI: 10.1002/14651858.CD011761.pub2]

\section{Heazell 2015}

Heazell AE, Whitworth M, Duley L, Thornton JG. Use of biochemical tests of placental function for improving pregnancy outcome. Cochrane Database of Systematic Reviews 2015, Issue 11. [DOI: 10.1002/14651858.CD011202.pub2]

\section{Hofmeyr 2016}

Hofmeyr GJ, Kiiza JA. Amnioinfusion for chorioamnionitis. Cochrane Database of Systematic Reviews 2016, Issue 8. [DOI: 10.1002/14651858.CD011622.pub2]

\section{Hofmeyr 2017}

Hofmeyr GJ, Manyame S. Calcium supplementation commencing before or early in pregnancy, or food fortification with calcium, for preventing hypertensive disorders of pregnancy. Cochrane Database of Systematic Reviews 2017, Issue 9. [DOI: 10.1002/14651858.CD011192.pub2]

\section{Hutton 2015}

Hutton EK, Hofmeyr GJ, Dowswell T. External cephalic version for breech presentation before term. Cochrane Database of Systematic Reviews 2015, Issue 7. [DOI: 10.1002/14651858.CD000084.pub3] 


\section{Iheozor-Ejiofor 2017}

Iheozor-Ejiofor Z, Middleton P, Esposito M, Glenny A-M. Treating periodontal disease for preventing adverse birth outcomes in pregnant women. Cochrane Database of Systematic Reviews 2017, Issue 6. [DOI: 10.1002/14651858.CD005297.pub3]

\section{Jahanfar 2014}

Jahanfar S, Howard LM, Medley N. Interventions for preventing or reducing domestic violence against pregnant women. Cochrane Database of Systematic Reviews 2014, Issue 11. [DOI: 10.1002/14651858.CD009414.pub3]

\section{Jahanfar 2015}

Jahanfar S, Jaafar SH. Effects of restricted caffeine intake by mother on fetal, neonatal and pregnancy outcomes. Cochrane Database of Systematic Reviews 2015, Issue 6. [DOI: 10.1002/14651858.CD006965.pub4]

\section{Low 2016}

Low N, Redmond S, Uusküla A, van Bergen J, Ward H, Andersen $\mathrm{B}$, et al. Screening for genital chlamydia infection. Cochrane Database of Systematic Reviews 2016, Issue 9. [DOI: 10.1002/14651858.CD010866.pub2]

\section{Martis 2016}

Martis R, Brown J, Alsweiler J, Crawford TJ, Crowther CA. Different intensities of glycaemic control for women with gestational diabetes mellitus. Cochrane Database of Systematic Reviews 2016, Issue 4. [DOI: 10.1002/14651858.CD011624.pub2]

\section{Matthews 2015}

Matthews A, Haas DM, O'Mathúna DP, Dowswell T. Interventions for nausea and vomiting in early pregnancy. Cochrane Database of Systematic Reviews 2015, Issue 9. [DOI: 10.1002/14651858.CD007575.pub4]

\section{Mbuagbaw 2015}

Mbuagbaw L, Medley N, Darzi AJ, Richardson M, Habiba GK, Ongolo-Zogo P. Health system and community level interventions for improving antenatal care coverage and health outcomes. Cochrane Database of Systematic Reviews 2015, Issue 12. [DOI: 10.1002/14651858.CD010994.pub2]

\section{McCauley 2015}

McCauley ME, van den Broek N, Dou L, Othman M. Vitamin A supplementation during pregnancy for maternal and newborn outcomes. Cochrane Database of Systematic Reviews 2015, Issue 10. [DOI: 10.1002/14651858.CD008666.pub3]

\section{Middleton 2016}

Middleton P, Crowther CA, Simmonds L. Different intensities of glycaemic control for pregnant women with pre-existing diabetes. Cochrane Database of Systematic Reviews 2016, Issue 5. [DOI: 10.1002/14651858.CD008540.pub4]

\section{Moy 2017}

Moy FM, Ray A, Buckley BS, West HM. Techniques of monitoring blood glucose during pregnancy for women with pre-existing diabetes. Cochrane Database of Systematic Reviews 2017, Issue 6. [DOI: 10.1002/14651858.CD009613.pub3]

\section{Muktabhant 2015}

Muktabhant B, Lawrie TA, Lumbiganon P, Laopaiboon M. Diet or exercise, or both, for preventing excessive weight gain in pregnancy. Cochrane Database of Systematic Reviews 2015, Issue 6. [DOI: 10.1002/14651858.CD007145.pub3]

\section{O'Neill 2017}

O'Neill SM, Kenny LC, Khashan AS, West HM, Smyth RM, Kearney PM. Different insulin types and regimens for pregnant women with pre-existing diabetes. Cochrane Database of Systematic Reviews 2017, Issue 2. [DOI: 10.1002/14651858.CD011880.pub2]

\section{Opray 2015}

Opray N, Grivell RM, Deussen AR, Dodd JM. Directed preconception health programs and interventions for improving pregnancy outcomes for women who are overweight or obese. Cochrane Database of Systematic Reviews 2015, Issue 7. [DOI: 10.1002/14651858.CD010932.pub2]

\section{Ota 2015a}

Ota E, Mori R, Middleton P, Tobe-Gai R, Mahomed K, Miyazaki C, et al. Zinc supplementation for improving pregnancy and infant outcome. Cochrane Database of Systematic Reviews 2015, Issue 2. [DOI: 10.1002/14651858.CD000230.pub5]

\section{Ota 2015b}

Ota E, Hori H, Mori R, TobeGai R, Farrar D. Antenatal dietary education and supplementation to increase energy and protein intake. Cochrane Database of Systematic Reviews 2015, Issue 6. [DOI: 10.1002/14651858.CD000032.pub3]

\section{Peña-Rosas 2015a}

Peña-Rosas JP, De-Regil LM, Garcia-Casal MN, Dowswell T. Daily oral iron supplementation during pregnancy. Cochrane Database of Systematic Reviews 2015, Issue 7. [DOI: 10.1002/14651858.CD004736.pub5]

\section{Peña-Rosas 2015b}

Peña-Rosas JP, De-Regil LM, Gomez Malave H, FloresUrrutia MC, Dowswell T. Intermittent oral iron supplementation during pregnancy. Cochrane Database of Systematic Reviews 2015, Issue 10. [DOI: 10.1002/14651858.CD009997.pub2]

\section{Phupong 2015}

Phupong V, Hanprasertpong T. Interventions for heartburn in pregnancy. Cochrane Database of Systematic Reviews 2015, Issue 9. [DOI: 10.1002/14651858.CD011379.pub2]

\section{Radeva-Petrova 2014}

Radeva-Petrova D, Kayentao K, ter Kuile FO, Sinclair D, Garner P. Drugs for preventing malaria in pregnant women in endemic areas: any drug regimen versus placebo or no treatment. Cochrane Database of Systematic Reviews 2014, Issue 10. [DOI: 10.1002/14651858.CD000169.pub3]

\section{Rafael 2014}

Rafael TJ, Berghella V, Alfirevic Z. Cervical stitch (cerclage) for preventing preterm birth in multiple pregnancy. Cochrane Database of Systematic Reviews 2014, Issue 9. [DOI: 10.1002/14651858.CD009166.pub2] 


\section{Raman 2017}

Raman P, Shepherd E, Dowswell T, Middleton P, Crowther CA. Different methods and settings for glucose monitoring for gestational diabetes during pregnancy. Cochrane Database of Systematic Reviews 2017, Issue 10. [DOI: 10.1002/14651858.CD011069.pub2]

\section{Rumbold 2015a}

Rumbold A, Ota E, Nagata C, Shahrook S, Crowther CA. Vitamin C supplementation in pregnancy. Cochrane Database of Systematic Reviews 2015, Issue 9. [DOI: 10.1002/14651858.CD004072.pub3]

\section{Rumbold 2015b}

Rumbold A, Ota E, Hori H, Miyazaki C, Crowther C A. Vitamin E supplementation in pregnancy. Cochrane Database of Systematic Reviews 2015, Issue 9. [DOI: 10.1002/14651858.CD004069.pub3]

\section{Salam 2015a}

Salam RA, Haider BA, Humayun Q, Bhutta ZA. Effect of administration of antihelminthics for soil-transmitted helminths during pregnancy. Cochrane Database of Systematic Reviews 2015, Issue 6. [DOI: 10.1002/14651858.CD005547.pub3]

\section{Salam 2015b}

Salam RA, Das JK, Dojo SC, Lassi ZS, Bhutta ZA. Impact of Haemophilus influenzae type $B(\mathrm{Hib})$ and viral influenza vaccinations in pregnancy for improving maternal, neonatal and infant health outcomes. Cochrane Database of Systematic Reviews 2015, Issue 6. [DOI: 10.1002/14651858.CD009982.pub2]

\section{Salam 2015c}

Salam RA, Zuberi NF, Bhutta ZA. Pyridoxine (vitamin B6) supplementation during pregnancy or labour for maternal and neonatal outcomes. Cochrane Database of Systematic Reviews 2015, Issue 6. [DOI: 10.1002/14651858.CD000179.pub3]

\section{Sandall 2016}

Sandall J, Soltani H, Gates S, Shennan A, Devane D. Midwife-led continuity models versus other models of care for childbearing women. Cochrane Database of Systematic Reviews 2016, Issue 4. [DOI: 10.1002/14651858.CD004667.pub5]

\section{Sangkomkamhang 2015}

Sangkomkamhang US, Lumbiganon P, Prasertcharoensuk W, Laopaiboon M. Antenatal lower genital tract infection screening and treatment programs for preventing preterm delivery. Cochrane Database of Systematic Reviews 2015, Issue 2. [DOI: 10.1002/14651858.CD006178.pub3]

\section{Schneeberger 2015}

Schneeberger C, Geerlings SE, Middleton P, Crowther CA. Interventions for preventing recurrent urinary tract infection during pregnancy. Cochrane Database of Systematic Reviews 2015, Issue 7. [DOI: 10.1002/14651858.CD009279.pub3]

\section{Smaill 2015}

Smaill FM, Vazquez JC. Antibiotics for asymptomatic bacteriuria in pregnancy. Cochrane Database of Systematic Reviews 2015, Issue 8. [DOI: 10.1002/14651858.CD000490.pub3]

\section{Smyth 2015}

Smyth R, Aflaifel N, Bamigboye AA. Interventions for varicose veins and leg oedema in pregnancy. Cochrane Database of Systematic Reviews 2015, Issue 10. [DOI: 10.1002/14651858.CD001066.pub3]

\section{Sosa 2015}

Sosa CG, Althabe F, Belizán JM, Bergel E. Bed rest in singleton pregnancies for preventing preterm birth. Cochrane Database of Systematic Reviews 2015, Issue 3. [DOI: 10.1002/14651858.CD003581.pub3]

\section{Spencer 2015}

Spencer L, Bubner T, Bain E, Middleton P. Screening and subsequent management for thyroid dysfunction prepregnancy and during pregnancy for improving maternal and infant health. Cochrane Database of Systematic Reviews 2015, Issue 9. [DOI: 10.1002/14651858.CD011263.pub2]

\section{Suchdev 2015}

Suchdev PS, Peña-Rosas JP, De-Regil LM. Multiple micronutrient powders for home (point-of-use) fortification of foods in pregnant women. Cochrane Database of Systematic Reviews 2015, Issue 6. [DOI: 10.1002/14651858.CD011158.pub2]

\section{Terplan 2015}

Terplan M, Ramanadhan S, Locke A, Longinaker N, Lui S. Psychosocial interventions for pregnant women in outpatient illicit drug treatment programs compared to other interventions. Cochrane Database of Systematic Reviews 2015, Issue 4. [DOI: 10.1002/14651858.CD006037.pub3]

\section{Thinkhamrop 2015}

Thinkhamrop J, Hofmeyr GJ, Adetoro O, Lumbiganon P, Ota E. Antibiotic prophylaxis during the second and third trimester to reduce adverse pregnancy outcomes and morbidity. Cochrane Database of Systematic Reviews 2015, Issue 6. [DOI: 10.1002/14651858.CD002250.pub3]

\section{Tieu 2017a}

Tieu J, Shepherd E, Middleton P, Crowther CA. Interconception care for women with a history of gestational diabetes for improving maternal and infant outcomes. Cochrane Database of Systematic Reviews 2017, Issue 8. [DOI: 10.1002/14651858.CD010211.pub3]

\section{Tieu 2017b}

Tieu J, Shepherd E, Middleton P, Crowther CA. Dietary advice interventions in pregnancy for preventing gestational diabetes mellitus. Cochrane Database of Systematic Reviews 2017, Issue 1. [DOI: 10.1002/14651858.CD006674.pub3]

\section{Tieu 2017c}

Tieu J, Coat S, Hague W, Middleton P, Shepherd E. Oral antidiabetic agents for women with established diabetes/impaired glucose tolerance or previous gestational diabetes planning pregnancy, or pregnant women with pre-existing diabetes. Cochrane Database of Systematic Reviews 2017, Issue 10. [DOI: 10.1002/14651858.CD007724.pub3] 


\section{Tieu 2017d}

Tieu J, McPhee AJ, Crowther CA, Middleton P, Shepherd E. Screening for gestational diabetes mellitus based on different risk profiles and settings for improving maternal and infant health. Cochrane Database of Systematic Reviews 2017, Issue 8. [DOI: 10.1002/14651858.CD007222.pub4]

\section{Till 2015}

Till SR, Everetts D, Haas DM. Incentives for increasing prenatal care use by women in order to improve maternal and neonatal outcomes. Cochrane Database of Systematic Reviews 2015, Issue 12. [DOI: 10.1002/14651858.CD009916.pub2]

\section{Urquhart 2017}

Urquhart C, Currell R, Harlow F, Callow L. Home uterine monitoring for detecting preterm labour. Cochrane Database of Systematic Reviews 2017, Issue 2. [DOI: 10.1002/14651858.CD006172.pub4]

\section{Widmer 2015}

Widmer M, Lopez I, Gülmezoglu AM, Mignini L, Roganti A. Duration of treatment for asymptomatic bacteriuria during pregnancy. Cochrane Database of Systematic Reviews 2015, Issue 11. [DOI: 10.1002/14651858.CD000491.pub3]

\section{Wiysonge 2017}

Wiysonge CS, Ndze VN, Kongnyuy EJ, Shey MS. Vitamin A supplements for reducing mother-to-child HIV transmission. Cochrane Database of Systematic Reviews 2017, Issue 9. [DOI: 10.1002/14651858.CD003648.pub4]

\section{Yamasmit 2015}

Yamasmit W, Chaithongwongwatthana S, Tolosa JE, Limpongsanurak S, Pereira L, Lumbiganon P. Prophylactic oral betamimetics for reducing preterm birth in women with a twin pregnancy. Cochrane Database of Systematic Reviews 2015, Issue 12. [DOI: 10.1002/14651858.CD004733.pub4]

\section{Zhou 2015}

Zhou K, West HM, Zhang J, Xu L, Li W. Interventions for leg cramps in pregnancy. Cochrane Database of Systematic Reviews 2015, Issue 8. [DOI: 10.1002/14651858.CD010655.pub2]

\section{References to excluded reviews}

\section{Amaya-Guio 2016}

Amaya-Guio J, Viveros-Carreño DA, Sierra-Barrios EM, Martinez-Velasquez MY, Grillo-Ardila CF. Antibiotic treatment for the sexual partners of women with bacterial vaginosis. Cochrane Database of Systematic Reviews 2016, Issue 10. [DOI: 10.1002/14651858.CD011701.pub2]

\section{Balogun 2016a}

Balogun OO, da Silva Lopes K, Ota E, Takemoto Y, Rumbold A, Takegata M, et al. Vitamin supplementation for preventing miscarriage. Cochrane Database of Systematic Reviews 2016, Issue 5. [DOI: 10.1002/14651858.CD004073.pub4]

\section{Balogun 2016b}

Balogun OO, O'Sullivan EJ, McFadden A, Ota E, Gavine A, Garner CD, et al. Interventions for promoting the initiation of breastfeeding. Cochrane Database of Systematic Reviews 2016, Issue 11. [DOI: 10.1002/14651858.CD001688.pub3]

\section{Chi 2015}

Chi C-C, Wang S-H, Wojnarowska, Kirtschig G, Davies E, Bennett C. Safety of topical corticosteroids in pregnancy. Cochrane Database of Systematic Reviews 2015, Issue 10. [DOI: 10.1002/14651858.CD007346.pub3]

\section{Demicheli 2015}

Demicheli V, Barale A, Rivetti A. Vaccines for women for preventing neonatal tetanus. Cochrane Database of Systematic Reviews 2015, Issue 7. [DOI: 10.1002/14651858.CD002959.pub4]

\section{Dickinson 2014}

Dickinson H, Bain E, Wilkinson D, Middleton P, Crowther CA, Walker DW. Creatine for women in pregnancy for neuroprotection of the fetus. Cochrane Database of Systematic Reviews 2014, Issue 12. [DOI: 10.1002/14651858.CD010846.pub2]

\section{Frazer 2016}

Frazer K, Callinan JE, McHugh J, van Baarsel S, Clarke A, Doherty $\mathrm{K}$, et al. Legislative smoking bans for reducing harms from secondhand smoke exposure, smoking prevalence and tobacco consumption. Cochrane Database of Systematic Reviews 2016, Issue 2. [DOI: 10.1002/14651858.CD005992.pub3]

\section{Grivell 2014}

Grivell RM, Andersen C, Dodd JM. Prenatal versus postnatal repair procedures for spina bifida for improving infant and maternal outcomes. Cochrane Database of Systematic Reviews 2014, Issue 10. [DOI: 10.1002/14651858.CD008825.pub2]

\section{Hemmingsen 2017}

Hemmingsen B, Sonne DP, Metzendorf M-I, Richter B. Dipeptidyl-peptidase (DPP)-4 inhibitors and glucagon-like peptide (GLP)-1 analogues for prevention or delay of type 2 diabetes mellitus and its associated complications in people at increased risk for the development of type 2 diabetes mellitus. Cochrane Database of Systematic Reviews 2017, Issue 5. [DOI: 10.1002/14651858.CD012204.pub2]

\section{Heslop 2016}

Heslop R, Roberts H, Flower D, Jordan V. Interventions for men and women with their first episode of genital herpes. Cochrane Database of Systematic Reviews 2016, Issue 8. [DOI: 10.1002/14651858.CD010684.pub2]

\section{Jahanfar 2017}

Jahanfar S, Ho JJ, Jaafar SH, Abraha I, Nisenblat V, Ellis UM, et al. Ultrasound for diagnosis of birth weight discordance in twin pregnancies. Cochrane Database of Systematic Reviews 2017, Issue 3. [DOI: 10.1002/14651858.CD012553]

\section{Karanth 2015}

Karanth L, Barua A, Kanagasabai S, Nair S. Desmopressin acetate (DDAVP) for preventing and treating acute bleeds 
during pregnancy in women with congenital bleeding disorders. Cochrane Database of Systematic Reviews 2015, Issue 9. [DOI: 10.1002/14651858.CD009824.pub3]

\section{Khattri 2017}

Khattri S, Arora A, Sumanth KN, Prashanti E, Bhat KG, Kusum CK, et al. Adjunctive systemic antimicrobials for the non-surgical treatment of chronic and aggressive periodontitis. Cochrane Database of Systematic Reviews 2017, Issue 2. [DOI: 10.1002/14651858.CD012568]

\section{Li 2014}

Li C, Lv Z, Shi Z, Zhu Y, Li L, Wu Y, et al. Periodontal therapy for the management of cardiovascular disease in patients with chronic periodontitis. Cochrane Database of Systematic Reviews 2014, Issue 8. [DOI: 10.1002/14651858.CD009197.pub2]

\section{Li 2016}

Li L, Dou L, Leung PC, Chung TK, Wang CC. Chinese herbal medicines for unexplained recurrent miscarriage. Cochrane Database of Systematic Reviews 2016, Issue 1. [DOI: 10.1002/14651858.CD010568.pub2]

\section{Liddle 2015}

Liddle SD, Pennick V. Interventions for preventing and treating low-back and pelvic pain during pregnancy. Cochrane Database of Systematic Reviews 2015, Issue 9. [DOI: 10.1002/14651858.CD001139.pub4]

\section{Martineau 2016}

Martineau AR, Cates CJ, Urashima M, Jensen M, Griffiths AP, Nurmatov $\mathrm{U}$, et al. Vitamin $\mathrm{D}$ for the management of asthma. Cochrane Database of Systematic Reviews 2016, Issue 9. [DOI: 10.1002/14651858.CD011511.pub2]

\section{O'Doherty 2015}

O'Doherty L, Hegarty K, Ramsay J, Davidson LL, Feder G, Taft A. Screening women for intimate partner violence in healthcare settings. Cochrane Database of Systematic Reviews 2015, Issue 7. [DOI: 10.1002/14651858.CD007007.pub3]

\section{Okusanya 2016}

Okusanya BO, Oladapo OT. Prophylactic versus selective blood transfusion for sickle cell disease in pregnancy. Cochrane Database of Systematic Reviews 2016, Issue 12. [DOI: 10.1002/14651858.CD010378.pub3]

\section{Stock 2016}

Stock SJ, Bricker L, Norman JE, West HM. Immediate versus deferred delivery of the preterm baby with suspected fetal compromise for improving outcomes. Cochrane Database of Systematic Reviews 2016, Issue 7. [DOI: 10.1002/14651858.CD008968.pub3]

\section{Tieu $2017 f$}

Tieu J, Middleton P, Crowther CA, Shepherd E. Preconception care for diabetic women for improving maternal and infant health. Cochrane Database of Systematic Reviews 2017, Issue 8. [DOI: 10.1002/14651858.CD007776.pub3]

\section{Weston 2016}

Weston J, Bromley R, Jackson C F, Adab N, Clayton-Smith J, Greenhalgh J, et al. Monotherapy treatment of epilepsy in pregnancy: congenital malformation outcomes in the child. Cochrane Database of Systematic Reviews 2016, Issue 11. [DOI: 10.1002/14651858.CD010224.pub2]

\section{Whitworth 2015}

Whitworth M, Bricker L, Mullan C. Ultrasound for fetal assessment in early pregnancy. Cochrane Database of Systematic Reviews 2015, Issue 7. [DOI: 10.1002/14651858.CD007058.pub3]

\section{Wilkinson 2016}

Wilkinson D, Shepherd E, Wallace EM. Melatonin for women in pregnancy for neuroprotection of the fetus. Cochrane Database of Systematic Reviews 2016, Issue 3. [DOI: 10.1002/14651858.CD010527.pub2]

\section{Additional references}

\section{Anonymous 1977}

Anonymous. WHO: recommended definitions, terminology and format for statistical tables related to the perinatal period and use of a new certificate for the cause of perinatal deaths. Acta Obstetricia et Gynecologica Scandinavica 1977;56(3):247-53.

\section{Ballard 2017}

Ballard M, Montgomery P. Risk of bias in overviews of reviews: a scoping review of methodological guidance and four-item checklist. Research Synthesis Methods 2017;8:92-108. [DOI: 10.1002/jrsm.1229]

\section{Bamigboye 2003}

Bamigboye AA, Morris J. Oestrogen supplementation, mainly diethylstilbestrol, for preventing miscarriages and other adverse pregnancy outcomes. Cochrane Database of Systematic Reviews 2003, Issue 3. [DOI: 10.1002/14651858.CD004353]

\section{Barros 2015}

Barros FC, Papageorghiou AT, Victora CG, Noble JA, Pang R, lams J, et al. The distribution of clinical phenotypes of preterm birth syndrome implications for prevention. JAMA Pediatrics 2015;169(3):220-9. [DOI: 10.1001/jamapediatrics.2014.3040]

\section{Berghella 2017}

Berghella V, Palacio M, Ness A, Afirevic Z, Nicolaides KH, Saccone $G$. Cervical length screening for prevention of preterm birth in singleton pregnancy with threatened preterm labor: systematic review and meta-analysis of randomized controlled trials using individual patient-level data. Ultrasound in Obstetrics \& Gynecology 2017;49(3):322-9. [DOI: 10.1002/ uog.17388]

\section{Blencowe 2012}

Blencowe H, Cousens S, Oestergaard MZ, Chou D, Moller AB, Narwal R, et al. National, regional, and worldwide estimates of preterm birth rates in the year 2010 with time trends since 1990 for selected countries: a systematic analysis and 
implications. Lancet 2012;379(9832):2162-72. [DOI: 10.1016/ S0140-6736(12)60820-4]

\section{Blencowe 2013}

Blencowe H, Cousens S, Chou D, Oestergaard M, Say L, Moller AB, et al. Born too soon: the global epidemiology of 15 million preterm births. Reproductive Health 2013;10(Suppl 1):S2. [DOI: 10.1186/1742-4755-10-S1-S2]

\section{Burda 2016}

Burda B, Holmer H, Norris S. Limitations of A Measurement Tool to Assess Systematic Reviews (AMSTAR) and suggestions for improvement. Systematic Reviews 2016;5:58. [DOI: 10.1186/ s13643-016-0237-1]

\section{Carson 2015}

Carson C, Redshaw M, Gray R, Quigley M. Risk of psychological distress in parents of preterm children in the first year: evidence from the UK Millennium Cohort Study. BMJ Open 2015;5:e007942. [DOI: 10.1136/bmjopen-2015-007942]

\section{Ciapponi 2017}

Ciapponi A, Lewin S, Herrera C, Opiyo N, Pantoja T, Paulsen E, et al. Delivery arrangements for health systems in lowincome countries: an overview of systematic reviews. Cochrane Database of Systematic Reviews 2017, Issue 9. [DOI: 10.1002/14651858.CD011083.pub2]

\section{Covidence [Computer program]}

Veritas Health Innovation. Covidence. Version accessed November 2017. Melbourne, Australia: Veritas Health Innovation, issue Covidence [Computer program]. Version accessed 10 January 2017. Melbourne, Australia: Veritas Health Innovation. Available at www.covidence.org..

\section{Elliott 2017}

Elliott JH, Synnota A, Turnera T, Simmonds M, Alk E, McDonald S, et al. Living systematic review: 1 . Introductionthe why, what, when, and how. Journal of Clinical Epidemiology 2017;91:23-30. [DOI: 10.1016/j.jclinepi.2017.08.010]

\section{Faggion 2015}

Faggion CM. Critical appraisal of AMSTAR: challenges, limitations, and potential solutions from the perspective of an assessor. BMC Medical Research Methodology 2015;15:63. [DOI: 10.1186/s12874-015-0062-6]

\section{Farquhar 2018}

Farquhar C, Marjoribanks J. Assisted reproductive technology: an overview of Cochrane Reviews. Cochrane Database of Systematic Reviews 2018, Issue 8. [DOI: 10.1002/14651858.CD010537.pub5]

\section{Ferrero 2016}

Ferrero DM, Larson J, Jacobsson B, DiRenzo GC, Norman JE, Martin JN Jr, et al. Cross-country individual participant analysis of 4.1 million singleton births in 5 countries with very high human development index confirms known associations but provides no biologic explanation for $2 / 3$ of all preterm births. PLOS One 2016;11(9):e0162506. [DOI: 10.1371/ journal.pone.0162506]

\section{Guyatt 2011a}

Guyatt GH, Oxman AD, Schünemann HJ, Tugwell P, Knotterus A. GRADE guidelines: a new series of articles in the Journal of Clinical Epidemiology. Journal of Clinical Epidemiology 2011;64(4):380-2. [DOI: 10.1016/j.jclinepi.2010.09.011]

\section{Guyatt 2011b}

Guyatt GH, Oxman A, Kunz R, Brozek J, Alonso-Coello P, Rind D, et al. GRADE guidelines 6 . Rating the quality of evidenceimprecision. Journal of Clinical Epidemiology 2011;64:1283-93. [DOI: 10.1016/j.jclinepi.2011.01.012]

\section{Gyamfi-Bannerman 2014}

Gyamfi-Bannerman C, Ananth CV. Trends in spontaneous and indicated preterm delivery among singleton gestations in the United States, 2005-2012. Obstetrics and Gynecology 2014;124:1069-74. [DOI: 10.1097/AOG.0000000000000546]

\section{Gülmezoglu 2011}

Gülmezoglu AM, Azhar M. Interventions for trichomoniasis in pregnancy. Cochrane Database of Systematic Reviews 2011, Issue 5. [DOI: 10.1002/14651858.CD000220.pub2]

\section{Higgins 2011a}

Higgins J, Altman D, Gotzsche P, Juni P, Moher D, Oxman AD, et al. The Cochrane Collaboration's tool for assessing risk of bias in randomised trials. BMJ 2011;343:d5928. [DOI: 10.1136/ bmj.d5928]

\section{Higgins 2011b}

Higgins JP, Green S, editors. Cochrane Handbook for Systematic Reviews of Interventions Version 5.1.0. The Cochrane Collaboration, 2011. [www.cochrane-handbook.org]

\section{Higgins 2016}

Higgins JP, Lasserson T, Chandler J, Tovey D, Churchill R. Methodological Expectations of Cochrane InterventionReviews. Version 1.05. London: Cochrane, 2016. [http:// community.cochrane.org/mecir-manual]

\section{Higgins 2018}

Higgins JP, Lasserson T, Chandler J, Tovey D, Churchill R. Methodological Expectations of Cochrane Intervention Reviews. Version 1.05. London: Cochrane, 2018.

\section{Hodek 2011}

Hodek JM, von der Schulenburg JM, Mittendorf T. Measuring economic consequences of preterm birth - Methodological recommendations for the evaluation of personal burden on children and their caregivers. Health Economics Review 2011;1(1):6.

\section{Hultcrantz 2017}

Hultcrantz M, Rind D, Akl EA, Treweek S, Mustafa RA, lorio A, et al. The GRADE Working Group clarifies the construct of certainty of evidence. Journal of Clinical Epidemiology 2017;87:4-13. [DOI: 10.1016/j.jclinepi.2017.05.006] 


\section{Iams 2008}

lams JD, Romero R, Culhane JF, Goldenberg RL. Primary, secondary, and tertiary interventions to reduce the morbidity and mortality of preterm birth. Lancet 2008;371(9607):164-75.

\section{Jarde 2017a}

Jarde A, Lutsiv O, Park CK, Beyene J, Dodd JM, Barrett J, et al. Effectiveness of progesterone, cerclage and pessary for preventing preterm birth in singleton pregnancies: a systematic review and network meta-analysis. BJOG: an international journal of obstetrics and gynaecology 2017;124:1176-89. [DOI: 10.1111/1471-0528.14624]

\section{Jarde 2017b}

Jarde A, Lutsiv O, Park CK, Barnett J, Beyene J, Saito S, et al. Preterm birth prevention in twin pregnancies with progesterone, pessary, or cerclage: a systematic review and meta-analysis. BJOG: an international journal of obstetrics and gynaecology 2017;124(1):1163-73. [DOI: 10.1111/1471-0528.14513]

\section{Jones 2012}

Jones L, Othman M, Dowswell T, Alfirevic Z, Gates S, Newburn M, et al. Pain management for women in labour: an overview of systematic reviews. Cochrane Database of Systematic Reviews 2012, Issue 3. [DOI: 10.1002/14651858.CD009234.pub2]

\section{Klerman 2001}

Klerman LV, Ramey SL, Goldenberg RL, Marbury S, Hou J, Cliver SP. A randomized trial of augmented prenatal care for multiple-risk, Medicaid-eligible African American women. American Journal of Public Health 2001;91(1):105-11. [DOI: 10.2105/AJPH.91.1.105]

\section{Lassi 2015}

Lassi Z, Middleton PF, Crowther C, Bhutta ZA. Interventions to improve neonatal health and later survival: an overview of systematic reviews. EBioMedicine 2015;2(8):985-1000. [DOI: 10.1016/j.ebiom.2015.05.023]

\section{Lawn 2016}

Lawn JE, Blencowe H, Kinney M, Bianchi F, Graham WJ. Evidence to inform maternal and newborn health. Best Practice \& Research. Clinical Obstetrics \& Gynaecology 2016;36:169-83.

\section{Liu 2015}

Liu L, Oza S, Hogan D, Perin J, Rudan I, Lawn JE, et al. Global, regional, and national causes of child mortality in 2000-13, with projections to inform post-2015 priorities: an updated systematic analysis. Lancet 2015;385(9966):430-40. [DOI: 10.1016/S0140-6736(14)61698-6]

\section{Lucaroni 2018}

Lucaroni F, Morciano L, Rizzo G, D'Antonio F, Buonuomo E, Palombi L, et al. Biomarkers for predicting spontaneous preterm birth: an umbrella systematic review. Journal of Maternal-fetal \& Neonatal Medicine 2018;31(6):726-34. [DOI: 10.1080/14767058.2017.1297404]

\section{Mangham 2009}

Mangham L, Petrou S, Doyle LW, Draper E, Marlow N. The cost of preterm birth throughout childhood in England and Wales. Pediatrics 2009;123:e312.

\section{Martin 2017}

Martin JN, D'Alton M, Jacobsson B, Norman JE. In pursuit of progress toward effective preterm birth reduction. Obstetrics and Gynecology 2017;129:715-9. [DOI: 10.1097/ AOG.0000000000001923]

\section{Medley 2018}

Medley N, Poljak B, Mammarella S, Alfirevic Z. Clinical guidelines for prevention and management of preterm birth: a systematic review. BJOG: an international journal of obstetrics and gynaecology 2018;125(11):1361-9. [DOI: 10.1111/1471-0528.15173]

\section{Nijman 2016}

Nijman TA, van Vilet EO, Koullai B, Mol BW, Oudijk MA. Antepartum and intrapartum interventions to prevent preterm birth and its sequelae. Seminars in Fetal \& Neonatal Medicine 2016;21(2):121-8. [DOI: 10.1016/j.siny.2016.01.004]

\section{Pieper 2012}

Pieper D, Buechter R, Jerinic P, Eikermann M. Overviews of reviews often have limited rigor: a systematic review. Journal of Clinical Epidemiology 2012;65:1267-73. [DOI: 10.1016/ j.jclinepi.2012.06.015]

\section{Piso 2014}

Piso B, Zechmeister-Koss I, Winkler R. Antenatal interventions to reduce preterm birth: an overview of Cochrane systematic reviews. BMC Research Notes 2014;7:265. [DOI: 10.1186/1756-0500-7-265]

\section{Pollock 2016}

Pollock M, Fernandes R, Becker L, Featherstone R, Hartling L. What guidance is available for researchers conducting overviews of reviews of healthcare interventions? A scoping review and qualitative metasummary. Systematic Reviews 2016;5:190. [DOI: 10.1186/s13643-016-0367-5]

\section{Pollock 2017}

Pollock M, Fernandes R, Hartling L. Evaluation of AMSTAR to assess the methodological quality of systematic reviews in overviews of reviews of healthcare interventions. $B M C$ Medical Research Methodology 2017;17:48. [DOI: 10.1186/ s12874-017-0325-5]

\section{Romero 2018}

Romero R, Conde-Agudelo A, Da Fonseca E, O'Brien JM, Cetingoz E, Creasy GW, et al. Vaginal progesterone for preventing preterm birth and adverse perinatal outcomes in singleton gestations with a short cervix: a meta-analysis of individual patient data. American Journal of Obstetrics and Gynecology 2018;218(2):161-80. [DOI: 10.1016/ j.ajog.2017.11.576] 


\section{Saccone 2017a}

Saccone G, Ciardulli A, Xodo S, Dugoff L, Ludmir J, D'Antonio F, et al. Cervical pessary for preventing preterm birth in twin pregnancies with short cervical length: asystematic review and meta-analysis. Journal of Maternal-fetal \& Neonatal Medicine 2017;30(24):2918-25. [DOI: 10.1080/14767058.2016.1268595]

\section{Saccone 2017b}

Saccone G, Ciardulli A, Xodo S, Dugoff L, Ludmir J, Pagani G, et al. Cervical pessary for preventing preterm birth in singleton pregnancies with short cervical length: a systematic review and meta-analysis. Journal of Ultrasound in Medicine 2017;36(8):1535-43. [DOI: 10.7863/ultra.16.08054]

\section{Santesso 2015a}

Santesso N, Oxman A. Presentation on GRADE. 2015 Cochrane Mid-Year Meeting, Athens, Greece; 3-8 May 2015.

\section{Santesso 2015b}

Santesso N, Rader T, Nilsen ES, Glenton C, Rosenbaum S, Ciapponi A, et al. A summary to communicate evidence from systematic reviews to the public improved understanding and accessibility of information: a randomized controlled trial. Journal of Clinical Epidemiology 2015;68:182-90. [DOI: 10.1016/ j.jclinepi.2014.04.009]

\section{Schünemann 2013}

Schünemann H, Brożek J, Guyatt G, Oxman A, eds. GRADE handbook for grading quality of evidence and strength of recommendations. GRADE handbook for grading quality of evidence and strength of recommendations. GRADE Working Group, 2013. [https://gdt.gradepro.org/app/handbook/ handbook.html]

\section{Shea 2007}

Shea B, Grimshaw JM, Wells GA, Boers M, Andersson N, Hamel C, et al. Development of AMSTAR: a measurement tool to assess the methodological quality of systematic reviews. BMC Medical Research Methodology 2007;7:10.

\section{Shepherd 2017}

Shepherd E, Salam R, Middleton P, Makrides M, McIntyre S, Badawi N, et al. Antenatal and intrapartum interventions for preventing cerebral palsy: an overview of Cochrane systematic reviews. Cochrane Database of Systematic Reviews 2017, Issue 8. [DOI: 10.1002/14651858.CD012077.pub2]

\section{Stewart 2017}

Stewart LA, Simmonds M, Duley L, Cietz KC, Harden M, Hodkinson $A$, et al. Evaluating progestogens for prevention of preterm birth international collaborative (EPPPIC) individual participant data (IPD) meta-analysis: protocol. Systematic Reviews 2017;6:235. [DOI: 10.1186/s13643-017-0600-x]

\section{van't Hooft 2016}

van't Hooft J, Duffy JM, Daly M, Williamson PR, Meher S, Thom E, et al. A core outcome set for evaluation of interventions to prevent preterm birth. Obstetrics and Gynecology 2016;127(1):49-58. [DOI: 10.1097/AOG.0000000000001195]

\section{Vigod 2010}

Vigod SN, Villegas L, Dennis CL, Ross L. Prevalence and risk factors for postpartum depression among women with preterm and low birthweight infants: a systematic review. BJOG: an international journal of obstetrics and gynaecology 2010;117:540-50.

\section{Villar 2012}

Villar J, Papageorghiou AT, Knight HE, Gravett M, lams J, Waller SA, et al. The preterm birth syndrome: a prototype phenotypic classification. American Journal of Obstetrics and Gynecology 2012;206(2):119-23. [DOI: 10.1016/ j.ajog.2011.10.866]

\section{Wegewitz 2016}

Wegewitz U, Weikert B, Fishta A, Jacobs A, Pieper D. Resuming the discussion of AMSTAR:What can (should) be made better?. BMC Medical Research Methodology 2016;16:111. [DOI: 10.1186/ s12874-016-0183-6]

\section{Welsh 2015}

Welsh EJ, Evans DJ, Fowler SJ, Spencer S. Interventions for bronchiectasis: an overview of Cochrane systematic reviews. Cochrane Database of Systematic Reviews 2015, Issue 7. [DOI: 10.1002/14651858.CD010337.pub2]

\section{Whiting 2016}

Whiting P, Savovic J, Higgins JP, Caldwell DM, Reeves BC, Shea B, et al. ROBIS: A new tool to assess risk of bias in systematic reviews was developed. Journal of Clinical Epidemiology 2016;69:225-34. [DOI: 10.1016/ j.jclinepi.2015.06.005]

\section{Yoshida 2016}

Yoshida S, Martines J, Lawn JE, Wall S, Souza JP, Rudan I, et al. Setting research priorities to improve global newborn health and prevent stillbirths by 2025. Journal of Global Health 2016;6(1):010508. [DOI: 10.7189/jogh.06.010508]

\section{References to other published versions of this review Medley 2017 \\ Medley N, Vogel JP, Care A, Alfirevic Z. Interventions during pregnancy to prevent spontaneous preterm birth: an overview of Cochrane systematic reviews. Cochrane Database of Systematic Reviews 2017, Issue 1. [DOI: 10.1002/14651858.CD012505]}

\section{ADDITIONAL TABLES}

Table 1. Characteristics of included systematic reviews

\begin{tabular}{llllll}
\hline $\begin{array}{l}\text { Review ID and } \\
\text { title }\end{array}$ & $\begin{array}{l}\text { Search date } \\
\text { (CPC regis- } \\
\text { ter) }\end{array}$ & $\begin{array}{l}\text { No. included } \\
\text { trials }\end{array}$ & $\begin{array}{l}\text { No. included } \\
\text { participants } \\
\text { (women) }\end{array}$ & $\begin{array}{l}\text { Overview } \\
\text { outcomes re- } \\
\text { ported }\end{array}$ & Review authors' conclusions \\
\hline
\end{tabular}


Table 1. Characteristics of included systematic reviews (Continued)

(quoted directly from published Cochrane Review)

\begin{tabular}{llll}
\hline Alfirevic 2015 & 28 February & 5 & 14,185 \\
& 2015 & & \\
Fetal and um- & & \\
bilical Doppler & & \\
ultrasound in & & \\
normal preg- & & \\
nancy. &
\end{tabular}

Alfirevic 2017a 30 June $2016 \quad 15 \quad 3490$

Cervical stitch

(cerclage) for

preventing

preterm birth in

singleton preg-

nancy.
1. Perinatal death with anomalies
2. Any death after ran- domisation
3. Neonatal death (to 28 days)
4. Stillbirth
5. Potentially pre- ventable perinatal death
6. Preterm birth $<37$ weeks
7. Gestational age at birth

1. Perinatal death

2. Stillbirth

3. Neonatal death

4. Preterm birth $<37,<$ 34 and $<28$ weeks
Existing evidence does not provide conclusive evidence that the use of routine umbilical artery Doppler ultrasound, or combination of umbilical and uterine artery Doppler ultrasound in low-risk or unselected populations benefits either mother or baby. Future studies should be designed to address small changes in perinatal outcome, and should focus on potentially preventable deaths.
Cervical cerclage reduces the risk of preterm birth in women at high risk of preterm birth and probably reduces risk of perinatal deaths. There was no evidence of any differential effect of cerclage based on previous obstetric history or short cervix indications, but data were limited for all clinical groups. The question of whether cerclage is more or less effective than other preventative treatments, particularly vaginal progesterone, remains unanswered.

Alfirevic 2017b $\quad 31$ March $2017 \quad 19 \quad 10,667$

Fetal and umbilical Doppler ultrasound in high-risk pregnancies

Alfirevic $2017 b$
Fetal and um-
bilical Doppler
ultrasound in
high-risk preg-
nancies

10,667

Bain 2014
Interventions
for managing
asthma in preg-
nancy.

2 June $2014 \quad 8 \quad 1181$

death

2. Stillbirth

3. Neonatal death

4. Preterm birth

\section{Perinatal} death

2. Preterm labour $<37$ weeks
Current evidence suggests that the use of Doppler ultrasound on the umbilical artery in high-risk pregnancies reduces the risk of perinatal deaths and may result in fewer obstetric interventions. The results should be interpreted with caution, as the evidence is not of high quality. Serial monitoring of Doppler changes in ductus venosus may be beneficial, but more studies of high quality with follow-up including neurological development are needed for evidence to be conclusive.
Based on eight included trials, of moderate quality overall, no firm conclusions about optimal interventions for managing asth- ma in pregnancy can be made. Five trials assessing pharmacological interventions did not provide clear evidence of benefits or harms to support or refute current prac- tice.


Table 1. Characteristics of included systematic reviews (Continued)

5. Gestational age at birth

\begin{tabular}{|c|c|c|c|c|c|}
\hline $\begin{array}{l}\text { Bain } 2015 \\
\text { Diet and exer- } \\
\text { cise interven- } \\
\text { tions for pre- } \\
\text { venting gesta- } \\
\text { tional diabetes } \\
\text { mellitus. } \\
\text { This review was } \\
\text { updated as }\end{array}$ & $\begin{array}{l}11 \text { February } \\
2014\end{array}$ & 13 & 4983 & $\begin{array}{l}\text { 1. Perinatal } \\
\text { death } \\
\text { 2. Stillbirth } \\
\text { 3. Neonatal } \\
\text { death } \\
\text { 4. Preterm } \\
\text { birth } \\
\text { 5. Gestational } \\
\text { age at birth }\end{array}$ & $\begin{array}{l}\text { Based on the data currently available, con- } \\
\text { clusive evidence is not available to guide } \\
\text { practice. }\end{array}$ \\
\hline $\begin{array}{l}\text { Boelig } 2016 \\
\text { Interventions } \\
\text { for treating } \\
\text { hyperemesis } \\
\text { gravidarum. }\end{array}$ & $\begin{array}{l}20 \text { December } \\
2015\end{array}$ & 25 & $\begin{array}{l}2052 \text { across } 18 \\
\text { comparisons }\end{array}$ & $\begin{array}{l}\text { 1. Stillbirth } \\
\text { and neona- } \\
\text { tal death } \\
\text { 2. Preterm } \\
\text { birth }\end{array}$ & $\begin{array}{l}\text { On the basis of this review, there is little } \\
\text { high-quality and consistent evidence sup- } \\
\text { porting any one intervention, which should } \\
\text { be taken into account when making man- } \\
\text { agement decisions. }\end{array}$ \\
\hline $\begin{array}{l}\text { Bricker 2015a } \\
\text { Routine ultra- } \\
\text { sound in late } \\
\text { pregnancy (af- } \\
\text { ter } 24 \text { weeks' } \\
\text { gestation). }\end{array}$ & 31 May 2015 & 13 & 34,980 & $\begin{array}{l}\text { 1. Perinatal } \\
\text { death } \\
\text { 2. Stillbirth } \\
\text { 3. Neonatal } \\
\text { death } \\
\text { 4. Preterm } \\
\text { birth } \\
\text { 5. Gestational } \\
\text { age at birth }\end{array}$ & $\begin{array}{l}\text { Based on existing evidence, routine late } \\
\text { pregnancy ultrasound in low-risk or uns- } \\
\text { elected populations does not confer ben- } \\
\text { efit on mother or baby. There was no dif- } \\
\text { ference in the primary outcomes of peri- } \\
\text { natal mortality, preterm birth less than } 37 \\
\text { weeks, caesarean section rates, and induc- } \\
\text { tion of labour rates if ultrasound in late } \\
\text { pregnancy was performed routinely versus } \\
\text { not performed routinely. }\end{array}$ \\
\hline
\end{tabular}

Bricker 2015b
Nutritional ad-
vice for improv-
ing outcomes in
multiple preg-
nancies.

\begin{tabular}{|c|c|c|c|c|c|}
\hline $\begin{array}{l}\text { Brown } 2016 \\
\text { Dietary supple- } \\
\text { mentation with } \\
\text { myo-inositol in } \\
\text { women during } \\
\text { pregnancy for } \\
\text { treating gesta- } \\
\text { tional diabetes. }\end{array}$ & 7 April 2016 & 2 & 142 & $\begin{array}{l}\text { 1. Preterm } \\
\text { birth }\end{array}$ & $\begin{array}{l}\text { There are insufficient data to evaluate the } \\
\text { effect of myo-inositol for the treatment of } \\
\text { gestational diabetes, with no data to ex- } \\
\text { amine the majority of outcomes in this re- } \\
\text { view. There do not appear to be any bene- } \\
\text { fits for the infant associated with exposure } \\
\text { to myo-inositol }\end{array}$ \\
\hline $\begin{array}{l}\text { Brown 2017a } \\
\text { Lifestyle inter- } \\
\text { ventions for the } \\
\text { treatment of } \\
\text { women with } \\
\text { gestational dia- } \\
\text { betes. }\end{array}$ & 14 May 2016 & 15 & 4501 & $\begin{array}{l}\text { 1. Perinatal } \\
\text { death } \\
\text { 2. Preterm } \\
\text { birth < } 37 \\
\text { and < } 32 \\
\text { weeks }\end{array}$ & $\begin{array}{l}\text { Lifestyle interventions are the primary } \\
\text { therapeutic strategy for women with GDM. } \\
\text { Women receiving lifestyle interventions } \\
\text { were less likely to have postnatal depres- } \\
\text { sion and were more likely to achieve post- } \\
\text { partum weight goals. Exposure to lifestyle } \\
\text { interventions was associated with a de- } \\
\text { creased risk of the baby being born LGA } \\
\text { and decreased neonatal adiposity. Long- } \\
\text { term maternal and childhood/adulthood }\end{array}$ \\
\hline
\end{tabular}


outcomes were poorly reported. The value of lifestyle interventions in low- and middle-income countries or for different ethnicities remains unclear. The longer-term benefits or harms of lifestyle interventions remains unclear due to limited reporting.

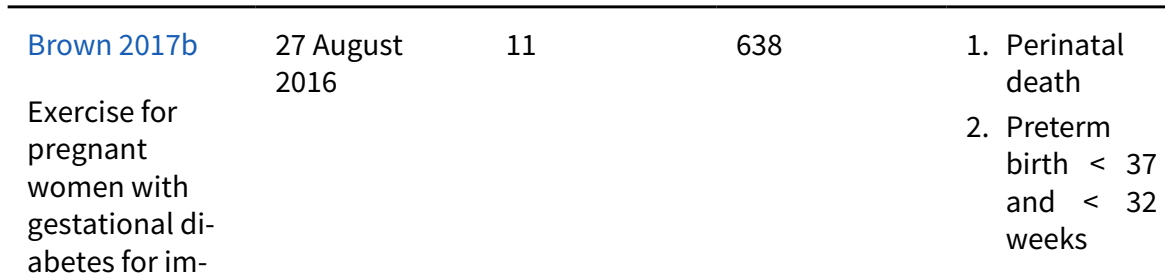

Short- and long-term outcomes of interest for this review were poorly reported. Current evidence is confounded by the large variety of exercise interventions. There was insufficient high-quality evidence to be able to determine any differences between exercise and control groups for our outcomes of interest.

proving mater-

nal and fetal

outcomes.

\section{Brown 2017c}

14 May $2016 \quad 11 \quad 1487 \quad$ None

Oral anti-diabetic pharmacological therapies for the treatment of women with gestational diabetes.

None

There were insufficient data comparing oral anti-diabetic pharmacological therapies with placebo/standard care (lifestyle advice) to inform clinical practice. There was insufficient high-quality evidence to be able to draw any meaningful conclusions as to the benefits of one oral anti-diabetic pharmacological therapy over another due to limited reporting of data for the primary and secondary outcomes in this review. Short- and long-term clinical outcomes for this review were inadequately reported or not reported. Current choice of oral anti-diabetic pharmacological therapy appears to be based on clinical preference, availability and national clinical practice guidelines.

\begin{tabular}{|c|c|c|c|c|c|}
\hline $\begin{array}{l}\text { Buppasiri } 2015 \\
\text { Calcium sup- } \\
\text { plementation } \\
\text { (other than for } \\
\text { preventing or } \\
\text { treating hyper- } \\
\text { tension) for im- } \\
\text { proving preg- } \\
\text { nancy and in- } \\
\text { fant outcomes. }\end{array}$ & $\begin{array}{l}\text { 30th Septem- } \\
\text { ber } 2014\end{array}$ & 25 & 18587 & $\begin{array}{l}\text { 1. Perinatal } \\
\text { death } \\
\text { 2. Stillbirth or } \\
\text { fetal death } \\
\text { 3. Preterm } \\
\text { birth }\end{array}$ & $\begin{array}{l}\text { This review indicates that there are no } \\
\text { clear additional benefits to calcium supple- } \\
\text { mentation in prevention of preterm birth } \\
\text { or low infant birthweight. }\end{array}$ \\
\hline
\end{tabular}

There is no randomised trial evidence currently available. Further randomised trials are required to accurately assess whether the improvement in detection shown is secondary to customised charts alone or an effect of the policy change. 
Table 1. Characteristics of included systematic reviews (Continued) risk pregnant women.

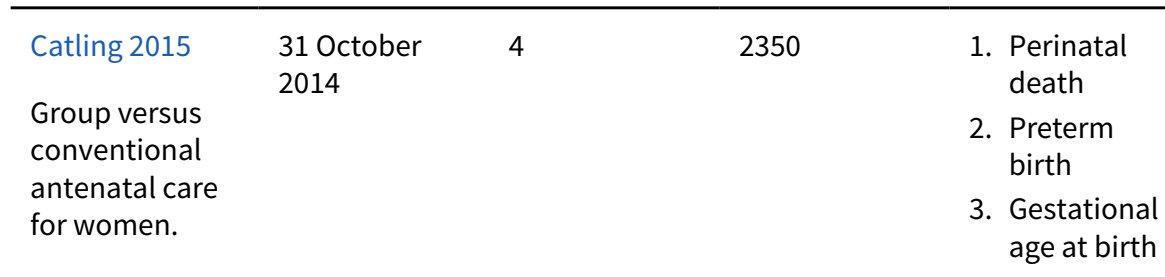

Available evidence suggests that group antenatal care is acceptable to women and is associated with no adverse outcomes for them or for their babies. No differences in the rate of preterm birth were reported when women received group antenatal care. This review is limited because of the small numbers of studies and women, and because one study contributed $42 \%$ of the women. Most of the analyses are based on a single study. Additional research is required to determine whether group antenatal care is associated with significant benefit in terms of preterm birth or birthweight.

\begin{tabular}{|c|c|c|c|c|c|}
\hline $\begin{array}{l}\text { Chamberlain } \\
2017 \\
\text { Psychosocial } \\
\text { interventions }\end{array}$ & $\begin{array}{l}13 \text { November } \\
2015\end{array}$ & 102 & 28,000 & $\begin{array}{l}\text { 1. Perinatal } \\
\text { death } \\
\text { 2. Preterm } \\
\text { birth < } 37 \\
\text { weeks }\end{array}$ & $\begin{array}{l}\text { Psychosocial interventions to support } \\
\text { women to stop smoking in pregnancy can } \\
\text { increase the proportion of women who } \\
\text { stop smoking in late pregnancy and the } \\
\text { proportion of infants born low birthweight. }\end{array}$ \\
\hline
\end{tabular}

stop smoking in

pregnancy.

\begin{tabular}{|c|c|c|c|c|}
\hline $\begin{array}{l}\text { Cluver } 2017 \\
\text { Interventions } \\
\text { for treating } \\
\text { genital Chlamy- } \\
\text { dia trachoma- } \\
\text { tis infection in } \\
\text { pregnancy. }\end{array}$ & 26 June 2017 & 15 & 1754 & $\begin{array}{l}\text { 1. Perinatal } \\
\text { death } \\
\text { 2. Preterm } \\
\text { birth }\end{array}$ \\
\hline
\end{tabular}
Treatment with antibacterial agents achieves microbiological cure from $C$. trachomatis infection during pregnan- cy. There was no apparent difference be- tween assessed agents (amoxicillin, ery- thromycin, clindamycin, azithromycin) in terms of efficacy (microbiological cure and repeat infection) and pregnancy com- plications (preterm birth, preterm rup- ture of membranes, low birthweight). Azithromycin and clindamycin appear to result in fewer side effects than ery- thromycin.

\begin{tabular}{|c|c|c|c|c|c|}
\hline $\begin{array}{l}\text { Coleman } 2015 \\
\text { Pharmacolog- } \\
\text { ical interven- } \\
\text { tions for pro- } \\
\text { moting smok- } \\
\text { ing cessation } \\
\text { during preg- } \\
\text { nancy. }\end{array}$ & 11 July 2015 & 9 & 2210 & $\begin{array}{l}\text { 1. Stillbirth } \\
\text { 2. Neonatal } \\
\text { death } \\
\text { 3. Preterm } \\
\text { birth }\end{array}$ & $\begin{array}{l}\text { There is no evidence that NRT used for } \\
\text { smoking cessation in pregnancy has either } \\
\text { positive or negative impacts on birth out- } \\
\text { comes. }\end{array}$ \\
\hline $\begin{array}{l}\text { da Silva Lopes } \\
2017 \\
\text { Bed rest with } \\
\text { and without } \\
\text { hospitalisa- } \\
\text { tion in multi- } \\
\text { ple pregnancy }\end{array}$ & 30 May 2016 & 6 & 636 & $\begin{array}{l}\text { 1. Preterm } \\
\text { birth }\end{array}$ & $\begin{array}{l}\text { The evidence to date is insufficient to in- } \\
\text { form a policy of routine bed rest in hospi- } \\
\text { tal or at home for women with a multiple } \\
\text { pregnancy. }\end{array}$ \\
\hline
\end{tabular}


Table 1. Characteristics of included systematic reviews (Continued)

for improving

perinatal out-

comes.

Davey 2015
Risk-scoring
systems for pre-
dicting preterm
birth with the
aim of reduc-
ing associat-
ed adverse out-
comes.

\begin{tabular}{llcll}
\hline $\begin{array}{l}\text { De-Regil } 2015 \\
\text { 31 August }\end{array}$ & 5 & 7391 & $\begin{array}{l}\text { 1. Stillbirth } \\
\text { 2. Neonatal } \\
\text { death }\end{array}$ & $\begin{array}{l}\text { Folic acid, alone or in combination with vi- } \\
\text { tamins and minerals, prevents neural tube } \\
\text { defects, but does not have a clear effect on } \\
\text { offects and }\end{array}$ \\
$\begin{array}{l}\text { safety of peri- } \\
\text { conceptional } \\
\text { oral folate sup- }\end{array}$ & & $\begin{array}{l}\text { 3. Preterm defects. } \\
\text { birth }\end{array}$ & \\
$\begin{array}{l}\text { plementation } \\
\text { for preventing }\end{array}$ & & & \\
birth defects. & & & \\
\hline
\end{tabular}

\begin{tabular}{llcc}
\hline $\begin{array}{l}\text { De-Regil } 2016 \\
\text { 23 February }\end{array}$ & 15 & 2388 & $\begin{array}{l}\text { 1. Stillbirth } \\
\text { Vitamin D sup- }\end{array}$ \\
$\begin{array}{ll}\text { plementation } \\
\text { for women dur- }\end{array}$ & & $\begin{array}{l}\text { Neonatal } \\
\text { death }\end{array}$ \\
ing pregnancy. & & 3. Preterm \\
birth
\end{tabular}

\begin{abstract}
New studies have provided more evidence on the effects of supplementing pregnant women with vitamin D alone or with calcium on pregnancy outcomes. Supplementing pregnant women with vitamin D in a single or continued dose increases serum 25-hydroxyvitamin D at term and may reduce the risk of pre-eclampsia, low birthweight and preterm birth. However, when vitamin $D$ and calcium are combined, the risk of preterm birth is increased. The clinical significance of the increased serum 25hydroxyvitamin D concentrations is still unclear. In light of this, these results need to be interpreted with caution. Data on adverse effects were lacking in all studies.
\end{abstract}

\begin{tabular}{|c|c|c|c|c|c|}
\hline $\begin{array}{l}\text { Dodd } 2015 a \\
\text { Reduction of } \\
\text { the number } \\
\text { of fetuses for } \\
\text { women with a } \\
\text { multiple preg- } \\
\text { nancy. }\end{array}$ & 31 July 2015 & 0 & 0 & None & $\begin{array}{l}\text { We found no available data from ran- } \\
\text { domised trials to inform the risks and ben- } \\
\text { efits of pregnancy reduction procedures } \\
\text { for women with a multiple pregnancy. } \\
\text { While randomised controlled trials will } \\
\text { provide the most reliable evidence about } \\
\text { the risks and benefits of fetal reduction } \\
\text { procedures, reduction in the number of fe- } \\
\text { tuses by selective termination may not be } \\
\text { acceptable to women, particularly couples } \\
\text { with a past history of infertility. The ac- } \\
\text { ceptability of this option, and willingness } \\
\text { to undergo randomisation will depend on } \\
\text { the couple's social background and beliefs, } \\
\text { and consequently, recruitment to such a } \\
\text { trial may prove exceptionally difficult. }\end{array}$ \\
\hline
\end{tabular}


Table 1. Characteristics of included systematic reviews (Continued)
Dodd 2015b
Specialised an- tenatal clinics for women with a multiple preg- nancy for im- proving mater- nal and infant outcomes.

31 May 2015

1

162
1. Perinatal death

2. Stillbirth

3. Neonatal death
There is currently limited information available from randomised controlled trials to assess the role of 'specialised' antenatal clinics for women with a multiple pregnancy compared with 'standard' antenatal care in improving maternal and infant health outcomes.

Dodd 2017
Prenatal ad-
ministration of
progestogens
for preventing
spontaneous
preterm birth in
women with a
multiple preg-
nancy.

1 November $\quad 17$
2016

17

$\sqrt{2}$

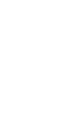

\begin{tabular}{llll}
\hline Dowswell $2015 \quad 23$ March $2015 \quad 7$ & 60,000
\end{tabular}

Alternative versus standard packages of antenatal care for low-risk pregnancy.

31 March $2016 \quad 5$

153

Continuous subcutaneous insulin infusion versus multiple daily injections of insulin for pregnant women with diabetes.
1. Perinatal death

2. Preterm birth $<37$, $<$ 34 and $<28$ weeks
Overall, for women with a multiple pregnancy, treatment with progesterone (either intramuscular or vaginal) does not appear to reduce the likelihood of preterm birth or improve outcomes for babies.

\begin{tabular}{|c|c|c|c|c|c|}
\hline $\begin{array}{l}\text { Farrar } 2017 \\
\text { Different strate- } \\
\text { gies for diag- } \\
\text { nosing gesta- } \\
\text { tional diabetes } \\
\text { to improve ma- } \\
\text { ternal and in- } \\
\text { fant health. }\end{array}$ & $\begin{array}{l}9 \text { January } \\
2017\end{array}$ & 7 & 1420 & $\begin{array}{l}\text { 1. Gestational } \\
\text { age at birth }\end{array}$ & $\begin{array}{l}\text { There is insufficient evidence to suggest } \\
\text { which strategy is best for diagnosing GDM. }\end{array}$ \\
\hline $\begin{array}{l}\text { Gomi } 2015 \\
\text { Routine blood } \\
\text { cultures in the }\end{array}$ & $\begin{array}{l}31 \text { December } \\
2014\end{array}$ & 0 & 0 & None & $\begin{array}{l}\text { There are no large-scale randomised con- } \\
\text { trolled trials to assess outcomes in the }\end{array}$ \\
\hline
\end{tabular}

Interventions during pregnancy to prevent preterm birth: an overview of Cochrane systematic reviews (Review)

Copyright ๑ 2018 The Cochrane Collaboration. Published by John Wiley \& Sons, Ltd. 
Table 1. Characteristics of included systematic reviews (Continued)

management

of pyelonephri-

tis in pregnancy

for improving

outcomes. management of pyelonephritis in pregnancy with or without blood cultures.

\begin{tabular}{|c|c|c|c|c|c|}
\hline $\begin{array}{l}\text { Grivell } 2015 \\
\text { Antenatal car- } \\
\text { diotocography } \\
\text { for fetal assess- } \\
\text { ment. }\end{array}$ & 26 June 2015 & 6 & 2105 & $\begin{array}{l}\text { 1. Perinatal } \\
\text { death } \\
\text { 2. Any poten- } \\
\text { tially pre- } \\
\text { ventable } \\
\text { perinatal } \\
\text { death } \\
\text { 3. GA at birth }\end{array}$ & $\begin{array}{l}\text { There is no clear evidence that antenatal } \\
\text { CTG improves perinatal outcome, but fur- } \\
\text { ther studies focusing on the use of com- } \\
\text { puterised CTG in specific populations of } \\
\text { women with increased risk of complica- } \\
\text { tions are warranted. }\end{array}$ \\
\hline
\end{tabular}

\begin{tabular}{|c|c|c|c|c|}
\hline Haider 2017 & 11 March 2015 & 19 & 138,538 & $\begin{array}{l}\text { 1. Perinatal } \\
\text { death }\end{array}$ \\
\hline $\begin{array}{l}\text { Multiple-mi- } \\
\text { cronutrient } \\
\text { supplementa- } \\
\text { tion for women } \\
\text { during preg- } \\
\text { nancy. }\end{array}$ & & & & $\begin{array}{l}\text { 2. Preterm } \\
\text { birth }\end{array}$ \\
\hline
\end{tabular}

Our findings support the effect of MMN supplements with iron and folic acid in improving some birth outcomes. Overall, pregnant women who received MMN supplementation had fewer low birthweight babies and small-for-gestational-age babies. The findings, consistently observed in several systematic evaluations of evidence, provide a basis to guide the replacement of iron and folic acid with MMN supplements containing iron and folic acid for pregnant women in low and middle-income countries where MMN deficiencies are common among women of reproductive age. Efforts could focus on the integration of this intervention in maternal nutrition and antenatal care programs in low- and middle-income countries.

\begin{tabular}{|c|c|c|c|c|c|}
\hline Han 2017 & 8 March 2016 & 19 & 1398 & $\begin{array}{l}\text { 1. Perinatal } \\
\text { death }\end{array}$ & $\begin{array}{l}\text { Evidence from } 19 \text { trials assessing differ- } \\
\text { ent types of dietary advice for women wit }\end{array}$ \\
\hline $\begin{array}{l}\text { Different types } \\
\text { of dietary ad- } \\
\text { vice for women } \\
\text { with gestation- } \\
\text { al diabetes. }\end{array}$ & & & & $\begin{array}{l}\text { 2. Preterm } \\
\text { birth }\end{array}$ & $\begin{array}{l}\text { GDM suggests no clear differences for pri- } \\
\text { mary outcomes and secondary outcomes } \\
\text { assessed using GRADE, except for a pos- } \\
\text { sible reduction in caesarean section for } \\
\text { women receiving a DASH diet compared } \\
\text { with a control diet. Few differences were } \\
\text { observed for secondary outcomes. }\end{array}$ \\
\hline
\end{tabular}

\begin{tabular}{|c|c|c|c|c|c|}
\hline $\begin{array}{l}\text { Harding } 2017 \\
\text { Iodine supple- } \\
\text { mentation for } \\
\text { women during } \\
\text { the preconcep- } \\
\text { tion, pregnan- } \\
\text { cy and postpar- } \\
\text { tum period }\end{array}$ & $\begin{array}{l}14 \text { November } \\
2016\end{array}$ & 11 & 2700 & $\begin{array}{l}\text { 1. Perinatal } \\
\text { death } \\
\text { 2. Preterm } \\
\text { birth }\end{array}$ & $\begin{array}{l}\text { There were insufficient data to reach any } \\
\text { meaningful conclusions on the benefits } \\
\text { and harms of routine iodine supplementa- } \\
\text { tion in women before, during or after preg- } \\
\text { nancy. }\end{array}$ \\
\hline $\begin{array}{l}\text { Heazell } 2015 \\
\text { Use of bio- } \\
\text { chemical tests } \\
\text { of placental } \\
\text { function for im- }\end{array}$ & 31 July 2015 & 3 & 740 & $\begin{array}{l}\text { 1. Perinatal } \\
\text { death (still- } \\
\text { birth or } \\
\text { neonatal } \\
\text { death to- } \\
\text { gether) }\end{array}$ & $\begin{array}{l}\text { There is insufficient evidence to support } \\
\text { the use of biochemical tests of placental } \\
\text { function to reduce perinatal mortality or } \\
\text { increase identification of small-for-gesta- } \\
\text { tional-age infants. However, we were only } \\
\text { able to include data from two studies that }\end{array}$ \\
\hline
\end{tabular}


Table 1. Characteristics of included systematic reviews (Continued) proving pregnancy out-

come.
2. Stillbirth

3. Neonatal death

4. Preterm birth measured oestrogens and $\mathrm{hPL}$. The quality of the evidence was low or very low.

\begin{tabular}{lllll}
\hline Hofmeyr 2016 & 6 July 2016 & 1 & 34 & None \\
Amnioinfusion & & & & \\
for chorioam- & & & \\
nionitis. & &
\end{tabular}

There is insufficient evidence to fully evaluate the effectiveness of using transcervical amnioinfusion for chorioamnionitis and to assess the safety of this intervention or women's satisfaction. We did not identify any trials that used transabdominal amnioinfusion.

Hofmeyr 2017
Calcium sup-
plementation
commencing
before or early
in pregnancy,
or food fortifi-
cation with cal-
cium, for pre-
venting hyper-
tensive disor-
ders of preg-
nancy.

\begin{tabular}{|c|c|c|c|}
\hline $\begin{array}{l}10 \text { August } \\
2017\end{array}$ & 1 & 60 & $\begin{array}{l}\text { 1. Perinatal } \\
\text { death }\end{array}$ \\
\hline
\end{tabular}
birth

Calcium supplementation ( $\geq 1 \mathrm{~g} /$ day) is associated with a significant reduction in the risk of pre-eclampsia, particularly for women with low-calcium diets. The treatment effect may be overestimated due to small-study effects or publication bias. It also reduces preterm birth and the occurrence of the composite outcome 'maternal death or serious morbidity'. We considered these benefits to outweigh the increased risk of HELLP syndrome, which was small in absolute numbers. The World Health Organization recommends calcium $1.5 \mathrm{~g}$ to $2 \mathrm{~g}$ daily for pregnant women with low dietary calcium intake.

Hutton 2015
External
cephalic ver-
sion for breech
presentation
before term.

31 March $2015 \quad 5 \quad 2187$

2187

1. Perinatal
death
2. Stillbirth
3. Preterm
labour
4. Stillbirth or
neonatal
death < 7
days

Compared with no ECV attempt, ECV commenced before term reduces non-cephalic presentation at birth. Compared with ECV at term, beginning ECV at between 34 to 35 weeks may have some benefit in terms of decreasing the rate of non-cephalic presentation, and risk of vaginal breech birth. However, early ECV may increase risk of late preterm birth, and it is important that any future research reports infant morbidity outcomes. Results of the review suggest that there is a need for careful discussion with women about the timing of the ECV procedure so that they can make informed decisions.

\begin{tabular}{|c|c|c|c|c|c|}
\hline $\begin{array}{l}\text { Iheozor-Ejiofor } \\
2017 \\
\text { Treating pe- } \\
\text { riodontal dis- } \\
\text { ease for pre- } \\
\text { venting adverse } \\
\text { birth outcomes } \\
\text { in pregnant } \\
\text { women }\end{array}$ & $\begin{array}{l}7 \text { October } \\
2016\end{array}$ & 15 & 7161 & $\begin{array}{l}\text { 1. Perinatal } \\
\text { death } \\
\text { 2. Preterm } \\
\text { birth < } 37 \\
\text { weeks }\end{array}$ & $\begin{array}{l}\text { It is not clear if periodontal treatment dur- } \\
\text { ing pregnancy has an impact on preterm } \\
\text { birth (low-quality evidence). There is low- } \\
\text { quality evidence that periodontal treat- } \\
\text { ment may reduce low birth weight }(<2500 \\
\text { g), however, our confidence in the effect } \\
\text { estimate is limited }\end{array}$ \\
\hline Jahanfar 2014 & 31 July 2014 & 10 & 3417 & $\begin{array}{l}\text { 1. Preterm } \\
\text { birth }\end{array}$ & $\begin{array}{l}\text { There is insufficient evidence to assess } \\
\text { the effectiveness of interventions for do- } \\
\text { mestic violence on pregnancy outcomes. }\end{array}$ \\
\hline
\end{tabular}


Table 1. Characteristics of included systematic reviews (Continued)

Interventions

for preventing

or reducing do-

mestic violence

against preg-

nant women.
There is a need for high-quality, RCTs with adequate statistical power to determine whether intervention programs prevent or reduce domestic violence episodes during pregnancy, or have any effect on maternal and neonatal mortality and morbidity outcomes.

\begin{tabular}{lllcl}
\hline Jahanfar 2015 & $\begin{array}{l}16 \text { January } \\
2016\end{array}$ & 1 & 1197 & $\begin{array}{l}\text { 1. Preterm } \\
\text { birth }\end{array}$ \\
Effects of re- & & &
\end{tabular}

Effects of re-

stricted caf-

feine intake by

mother on fe-

tal, neonatal

and pregnancy

outcomes.

There is insufficient evidence to confirm or refute the effectiveness of caffeine avoidance on birthweight or other pregnancy outcomes. There is a need to conduct highquality, double-blinded RCTs to determine whether caffeine has any effect on pregnancy outcome.

\begin{tabular}{llll}
\hline Low 2016 & $\begin{array}{l}\text { 14 February } \\
2016\end{array}$ & 359,078 & $\begin{array}{l}\text { None. No in- } \\
\text { cluded RCT } \\
\text { measured } \\
\text { the effects } \\
\text { ofrening for }\end{array}$ \\
$\begin{array}{l}\text { of screening } \\
\text { dia infection. }\end{array}$ & & $\begin{array}{l}\text { in pregnant } \\
\text { women }\end{array}$ \\
& &
\end{tabular}

There is an absence of RCT evidence about the effects of chlamydia screening in pregnancy. Future RCTs of chlamydia screening interventions should determine the effects of chlamydia screening in pregnancy, of repeated rounds of screening on the incidence of chlamydia-associated PID and chlamydia reinfection in general and highrisk populations.

$\begin{array}{lllrl}\text { Martis } 2016 & \begin{array}{l}\text { 31 January } \\ \text { 2016 }\end{array} & 1 & 180 & \begin{array}{l}\text { 1. Gestational } \\ \text { age at birth }\end{array} \\ \text { Different in- } & & & \end{array}$

tensities of glycaemic control for women with gestational diabetes mellitus.

There is insufficient evidence to guide clinical practice for targets for glycaemic control for women with GDM to minimise adverse effects on maternal and fetal health. Glycaemic target recommendations from international professional organisations for maternal glycaemic control vary widely and are reliant on consensus given the lack of high-quality evidence. Further highquality trials are needed, and these should compare different glycaemic targets for guiding treatment of women with GDM, assess both short-term and long-term health outcomes for women and their babies, include women's experiences and assess health services costs. Four studies are ongoing.

\begin{tabular}{|c|c|c|c|c|c|}
\hline $\begin{array}{l}\text { Matthews } 2015 \\
\text { Interventions } \\
\text { for nausea and } \\
\text { vomiting in ear- } \\
\text { ly pregnancy. }\end{array}$ & $\begin{array}{l}19 \text { January } \\
2015\end{array}$ & 41 & 5449 & $\begin{array}{l}\text { 1. Sponta- } \\
\text { neous } \\
\text { abortion } \\
\text { 2. Stillbirth } \\
\text { 3. Perinatal } \\
\text { death } \\
\text { 4. Preterm } \\
\text { birth }\end{array}$ & $\begin{array}{l}\text { Given the high prevalence of nausea and } \\
\text { vomiting in early pregnancy, women and } \\
\text { health professionals need clear guidance } \\
\text { about effective and safe interventions, } \\
\text { based on systematically reviewed evi- } \\
\text { dence. There is a lack of high-quality evi- } \\
\text { dence to support any particular interven- } \\
\text { tion. }\end{array}$ \\
\hline $\begin{array}{l}\text { Mbuagbaw } \\
2015 \\
\text { Health system } \\
\text { and communi- }\end{array}$ & 7 June 2015 & 34 & 400,000 & $\begin{array}{l}\text { 1. Perinatal } \\
\text { death } \\
\text { 2. Preterm } \\
\text { labour }\end{array}$ & $\begin{array}{l}\text { Single interventions may improve ANC cov- } \\
\text { erage (at least one visit and four or more } \\
\text { visits) and deliveries in health facilities. } \\
\text { Combined interventions may improve ANC } \\
\text { coverage (at least one visit), reduce peri- }\end{array}$ \\
\hline
\end{tabular}

Interventions during pregnancy to prevent preterm birth: an overview of Cochrane systematic reviews (Review)

Copyright (c) 2018 The Cochrane Collaboration. Published by John Wiley \& Sons, Ltd. 
Table 1. Characteristics of included systematic reviews (Continued)

ty level inter-

ventions for im-

proving antena-

tal care cover-

age and health

outcomes.

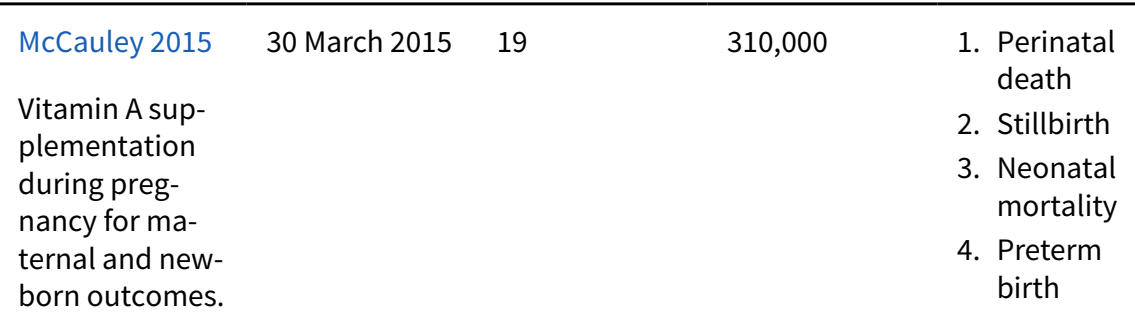

natal mortality and reduce the occurrence of low birthweight. The effects of the interventions are unrelated to whether they are community or health system interventions.
The pooled results of three large trials in Nepal, Ghana and Bangladesh (with over 153,500 women) do not currently suggest a role for antenatal vitamin A supplementation to reduce maternal or perinatal mortality. However, the populations studied were probably different with regard to baseline vitamin A status and there were problems with follow-up of women. There is good evidence that antenatal vitamin $\mathrm{A}$ supplementation reduces maternal night blindness, maternal anaemia for women who live in areas where vitamin A deficiency is common or who are HIV-positive. In addition, the available evidence suggests a reduction in maternal infection, but these data are not of a high quality.

$\begin{array}{lll}\text { Middleton } 2016 & \begin{array}{l}31 \text { January } \\ 2016\end{array} & 3\end{array}$

Different intensities of glycaemic control for pregnant women with pre-existing diabetes.

\section{3}

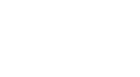

$-$

\author{
1. Perinatal \\ death \\ 2. Gestational \\ age at birth
}

In a very limited body of evidence, few differences in outcomes were seen between very tight and tight-moderate glycaemic control targets in pregnant women with pre-existing type 1 diabetes, including actual glycaemic control achieved. There is evidence of harm (increased pre-eclampsia, caesareans and birthweights greater than 90th centile) for 'loose' control (FBG above $7 \mathrm{mmol} / \mathrm{L}$ ). Future trials comparing interventions, rather than glycaemic control targets, may be more feasible. Trials in pregnant women with pre-existing type 2 diabetes are required.

1. Perinatal This review found no evidence that any death glucose monitoring technique is superior 2. Preterm to any other technique among pregnant birth women with pre-existing type 1 or type 2 diabetes. The evidence base for the effectiveness of monitoring techniques is weak and additional evidence from large welldesigned randomised trials is required to inform choices of glucose monitoring techniques.

\begin{tabular}{|c|c|c|c|c|c|}
\hline $\begin{array}{l}\text { Moy } 2017 \\
\text { Techniques } \\
\text { of monitor- } \\
\text { ing blood glu- } \\
\text { cose during } \\
\text { pregnancy for } \\
\text { women with } \\
\text { pre-existing di- } \\
\text { abetes. }\end{array}$ & $\begin{array}{l}30 \text { November } \\
2016\end{array}$ & 10 & 538 & $\begin{array}{l}\text { 1. Perinatal } \\
\text { death } \\
\text { 2. Preterm } \\
\text { birth }\end{array}$ & $\begin{array}{l}\text { This review found no evidence that any } \\
\text { glucose monitoring technique is superior } \\
\text { to any other technique among pregnant } \\
\text { women with pre-existing type } 1 \text { or type } 2 \\
\text { diabetes. The evidence base for the effec- } \\
\text { tiveness of monitoring techniques is weak } \\
\text { and additional evidence from large well- } \\
\text { designed randomised trials is required to } \\
\text { inform choices of glucose monitoring tech- } \\
\text { niques. }\end{array}$ \\
\hline
\end{tabular}

\begin{tabular}{|c|c|c|c|c|c|}
\hline $\begin{array}{l}\text { Muktabhant } \\
2015 \\
\text { Diet or exercise, } \\
\text { or both, for pre- } \\
\text { venting exces- } \\
\text { sive weight gain } \\
\text { in pregnancy. }\end{array}$ & $\begin{array}{l}5 \text { November } \\
2014\end{array}$ & $\begin{array}{l}65 \text { (49 with da- } \\
\mathrm{ta} \text { ) }\end{array}$ & 11,444 & $\begin{array}{l}\text { 1. Preterm } \\
\text { birth }\end{array}$ & $\begin{array}{l}\text { High-quality evidence indicates that diet or } \\
\text { exercise, or both, during pregnancy can re- } \\
\text { duce the risk of excessive GWG. Other ben- } \\
\text { efits may include a lower risk of caesarean } \\
\text { delivery, macrosomia, and neonatal respi- } \\
\text { ratory morbidity, particularly for high-risk } \\
\text { women receiving combined diet and exer- } \\
\text { cise interventions. Maternal hypertension } \\
\text { may also be reduced. Exercise appears to }\end{array}$ \\
\hline
\end{tabular}


be an important part of controlling weight gain in pregnancy and more research is needed to establish safe guidelines. Most included studies were carried out in developed countries and it is not clear whether these results are widely applicable to lower-income settings.

\begin{tabular}{|c|c|c|c|c|}
\hline O'Neill 2017 & 17 October & 5 & 554 & 1. Preterm \\
\hline $\begin{array}{l}\text { Different insulin } \\
\text { types and regi- } \\
\text { mens for preg- } \\
\text { nant women } \\
\text { with pre-exist- } \\
\text { ing diabetes. }\end{array}$ & & & & \\
\hline
\end{tabular}

With limited evidence and no meta-analyses, as each trial looked at a different comparison, no firm conclusions could be made about different insulin types and regimens in pregnant women with pre-existing type 1 or 2 diabetes. Further research is warranted to determine who has an increased risk of adverse pregnancy outcome. This would include larger trials, incorporating adequate randomisation and blinding, and key outcomes that include macrosomia, pregnancy loss, pre-eclampsia, caesarean section, fetal anomalies, and birth trauma.

\begin{tabular}{llll}
\hline Opray 2015 & $\begin{array}{l}31 \text { December } \\
2014\end{array}$ & 0 & None \\
Directed pre- & & \\
conception & & \\
health pro- & & \\
grams and in- & \\
terventions & \\
for improv- & \\
ing pregnancy \\
outcomes for \\
women who are \\
overweight or \\
obese.
\end{tabular}

We found no randomised controlled trials that assessed the effect of preconception health programs and interventions in overweight and obese women with the aim of improving pregnancy outcomes. Until the effectiveness of preconception health programs and interventions can be established, no practice recommendations can be made. Further research is required in this area.

\begin{tabular}{|c|c|c|c|c|c|}
\hline $\begin{array}{l}\text { Ota 2015a } \\
\text { Zinc supple- } \\
\text { mentation } \\
\text { for improving } \\
\text { pregnancy and } \\
\text { infant outcome. }\end{array}$ & $\begin{array}{l}31 \text { October } \\
2014\end{array}$ & 21 & 17,000 & $\begin{array}{l}\text { 1. Preterm } \\
\text { birth } \\
\text { 2. Stillbirth or } \\
\text { neonatal } \\
\text { death (re- } \\
\text { ported as a } \\
\text { single out- } \\
\text { come) } \\
\text { 3. Gestational } \\
\text { age at birth }\end{array}$ & $\begin{array}{l}\text { The evidence for a } 14 \% \text { relative reduction } \\
\text { in preterm birth for zinc compared with } \\
\text { placebo was primarily represented by trials } \\
\text { involving women of low income and this } \\
\text { has some relevance in areas of high-peri- } \\
\text { natal mortality. There was no convincing } \\
\text { evidence that zinc supplementation dur- } \\
\text { ing pregnancy results in other useful and } \\
\text { important benefits. Since the preterm as- } \\
\text { sociation could well reflect poor nutrition, } \\
\text { studies to address ways of improving the } \\
\text { overall nutritional status of populations in } \\
\text { impoverished areas, rather than focusing } \\
\text { on micronutrient and or zinc supplementa- } \\
\text { tion in isolation, should be an urgent prior- } \\
\text { ity. }\end{array}$ \\
\hline $\begin{array}{l}\text { Ota } 2015 \mathrm{~b} \\
\text { Antenatal di- } \\
\text { etary educa- } \\
\text { tion and sup- } \\
\text { plementation } \\
\text { to increase en- }\end{array}$ & $\begin{array}{l}31 \text { January } \\
2015\end{array}$ & 17 & 9030 & $\begin{array}{l}\text { 1. Stillbirth } \\
\text { 2. Neonatal } \\
\text { death } \\
\text { 3. Preterm } \\
\text { birth }\end{array}$ & $\begin{array}{l}\text { This review provides encouraging evidence } \\
\text { that antenatal nutritional education with } \\
\text { the aim of increasing energy and protein } \\
\text { intake in the general obstetric population } \\
\text { appears to be effective in reducing the risk } \\
\text { of preterm birth, low birthweight, increas- }\end{array}$ \\
\hline
\end{tabular}


Table 1. Characteristics of included systematic reviews (Continued) ergy and protein intake. ing head circumference at birth, increasing birthweight among undernourished women, and increasing protein intake. There was no evidence of benefit or adverse effect for any other outcome reported.

\begin{tabular}{|c|c|c|}
\hline $\begin{array}{l}\text { Peña-Rosas } \\
\text { 2015a }\end{array}$ & $\begin{array}{l}10 \text { January } \\
2015\end{array}$ & $\begin{array}{l}61 \text { (44 with da- } \\
\text { ta) }\end{array}$ \\
\hline
\end{tabular}

Daily oral iron supplementation during pregnancy.

\author{
1. Neonatal \\ death \\ 2. Preterm \\ birth
}

Supplementation reduces the risk of maternal anaemia and iron deficiency in pregnancy but the positive effect on other maternal and infant outcomes is less clear. Implementation of iron supplementation recommendations may produce heterogeneous results depending on the populations' background risk for low birthweight and anaemia, as well as the level of adherence to the intervention.

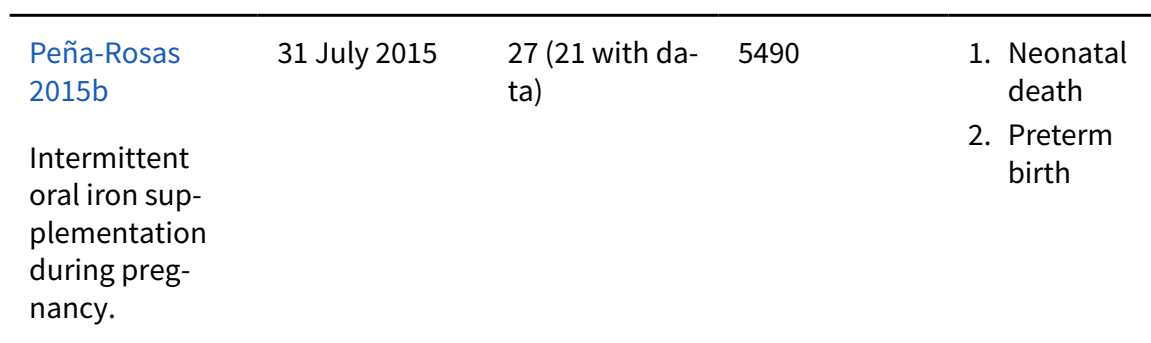
This review is the most comprehensive summary of the evidence assessing the benefits and harms of intermittent iron supplementation in pregnant women on haematological and pregnancy outcomes. Findings suggest that intermittent regi- mens produced similar maternal and in- fant outcomes as daily supplementation but were associated with fewer side effects and reduced the risk of high levels of $\mathrm{Hb}$ in mid and late pregnancy, although the risk of mild anaemia near term was increased. While the quality of the evidence was as- sessed as low or very low, intermittent may be a feasible alternative to daily iron supplementation among those pregnant women who are not anaemic and have ad- equate antenatal care.

\begin{tabular}{|c|c|c|c|}
\hline Phupong 2015 & 30 June 2015 & 9 & 725 \\
\hline
\end{tabular}

Further RCTs are needed to fully evaluate the effectiveness of interventions for heartburn in pregnancy. Future research should also address other medications such as histamine 2-receptor antagonists, promotility drugs, proton pump inhibitors, and a raft-forming alginate reflux suppressant in treatment of heartburn in pregnancy. More research is needed on acupuncture and other complimentary therapies as treatments for heartburn in pregnancy. Future research should also evaluate any adverse outcomes, maternal satisfaction with treatment and measure pregnant women's quality of life in relation to the intervention.

\begin{tabular}{|c|c|c|c|c|c|}
\hline $\begin{array}{l}\text { Radeva-Petrova } \\
2014 \\
\text { Drugs for pre- } \\
\text { venting malar- } \\
\text { ia in pregnant }\end{array}$ & 1 June 2014 & 17 & 14,481 & $\begin{array}{l}\text { 1. Stillbirth } \\
\text { 2. Perinatal } \\
\text { death } \\
\text { 3. Neonatal } \\
\text { and Infant } \\
\text { death }\end{array}$ & $\begin{array}{l}\text { Routine chemoprevention to prevent } \\
\text { malaria and its consequences has been } \\
\text { extensively tested in RCTs, with clinically } \\
\text { important benefits on anaemia and para- } \\
\text { sitaemia in the mother, and on birthweight } \\
\text { in infants. }\end{array}$ \\
\hline
\end{tabular}


Table 1. Characteristics of included systematic reviews (Continued)

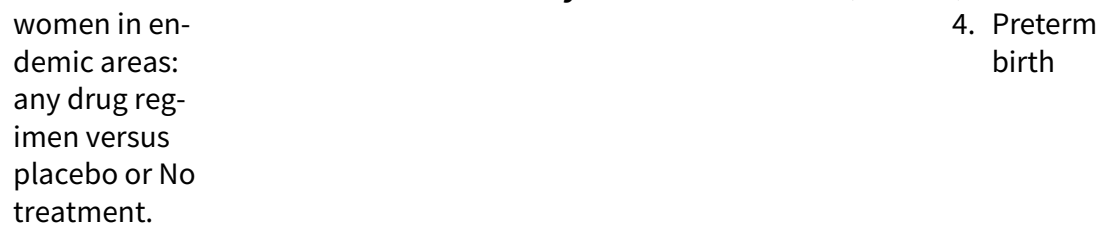

\begin{tabular}{|c|c|c|c|c|c|}
\hline $\begin{array}{l}\text { Rafael } 2014 \\
\text { Cervical stitch } \\
\text { (cerclage) for } \\
\text { preventing } \\
\text { preterm birth in } \\
\text { multiple preg- } \\
\text { nancy. }\end{array}$ & 30 June 2014 & 5 & 1577 & $\begin{array}{l}\text { 1. Perinatal } \\
\text { death } \\
\text { 2. Stillbirth } \\
\text { 3. Neonatal } \\
\text { death } \\
\text { 4. Preterm } \\
\text { birth } \\
\text { 5. Gestational } \\
\text { age at birth }\end{array}$ & $\begin{array}{l}\text { This review is based on limited data from } \\
\text { five small studies of average to above aver- } \\
\text { age quality. For multiple gestations, there } \\
\text { is no evidence that cerclage is an effective } \\
\text { intervention for preventing preterm births } \\
\text { and reducing perinatal deaths or neonatal } \\
\text { morbidity. }\end{array}$ \\
\hline
\end{tabular}

\begin{tabular}{|c|c|c|c|c|c|}
\hline $\begin{array}{l}\text { Raman } 2017 \\
\text { Different meth- } \\
\text { ods and set- } \\
\text { tings for glu- } \\
\text { cose monitor- }\end{array}$ & $\begin{array}{l}30 \text { September } \\
2016\end{array}$ & 11 & 1272 & $\begin{array}{l}\text { 1. Perinatal } \\
\text { death } \\
\text { 2. Preterm } \\
\text { birth }\end{array}$ & $\begin{array}{l}\text { Evidence from } 11 \text { RCTs assessing different } \\
\text { methods or settings for glucose monitoring } \\
\text { for GDM suggests no clear differences for } \\
\text { the primary outcomes or other secondary } \\
\text { outcomes assessed in this review. }\end{array}$ \\
\hline
\end{tabular}

ing for gesta-

tional diabetes

during preg-

nancy.

\begin{tabular}{|c|c|c|c|c|c|}
\hline $\begin{array}{l}\text { Rumbold 2015a } \\
\text { Vitamin C sup- } \\
\text { plementation } \\
\text { in pregnancy. }\end{array}$ & 31 March 2015 & 21 & 22,192 & $\begin{array}{l}\text { 1. Perinatal } \\
\text { death } \\
\text { 2. Stillbirth } \\
\text { 3. Neonatal } \\
\text { death } \\
\text { 4. Preterm } \\
\text { birth } \\
\text { 5. Gestational } \\
\text { age at birth }\end{array}$ & $\begin{array}{l}\text { The data do not support routine vitamin } \\
\text { C supplementation alone or in combina- } \\
\text { tion with other supplements for the pre- } \\
\text { vention of fetal or neonatal death, poor fe- } \\
\text { tal growth, preterm birth or pre-eclamp- } \\
\text { sia. Further research is required to eluci- } \\
\text { date the possible role of vitamin C in the } \\
\text { prevention of placental abruption and } \\
\text { prelabour rupture of membranes. There } \\
\text { was no convincing evidence that vitamin } \\
\text { C supplementation alone or in combina- } \\
\text { tion with other supplements results in oth- } \\
\text { er important benefits or harms. }\end{array}$ \\
\hline
\end{tabular}

\begin{tabular}{|c|c|c|c|c|c|}
\hline $\begin{array}{l}\text { Rumbold 2015b } \\
\text { Vitamin E sup- } \\
\text { plementation } \\
\text { in pregnancy. }\end{array}$ & 31 March 2015 & 29 & 24,300 & $\begin{array}{l}\text { 1. Stillbirth } \\
\text { 2. Neonatal } \\
\text { death } \\
\text { 3. Perinatal } \\
\text { death } \\
\text { 4. Preterm } \\
\text { birth } \\
\text { 5. Gestational } \\
\text { age at birth }\end{array}$ & $\begin{array}{l}\text { The data do not support routine vitamin E } \\
\text { supplementation in combination with oth- } \\
\text { er supplements for the prevention of still- } \\
\text { birth, neonatal death, preterm birth, pre- } \\
\text { eclampsia, preterm or term PROM or poor } \\
\text { fetal growth. Further research is required } \\
\text { to elucidate the possible role of vitamin E } \\
\text { in the prevention of placental abruption. } \\
\text { There was no convincing evidence that vi- } \\
\text { tamin E supplementation in combination } \\
\text { with other supplements results in other } \\
\text { important benefits or harms. }\end{array}$ \\
\hline $\begin{array}{l}\text { Salam } 2015 a \\
\text { Effect of ad- } \\
\text { ministra- } \\
\text { tion of anti- }\end{array}$ & $\begin{array}{l}31 \text { January } \\
2015\end{array}$ & 4 & 4265 & $\begin{array}{l}\text { 1. Perinatal } \\
\text { death } \\
\text { 2. Preterm } \\
\text { birth }\end{array}$ & $\begin{array}{l}\text { The evidence to date is insufficient to rec- } \\
\text { ommend use of antihelminthic for preg- } \\
\text { nant women after the first trimester of } \\
\text { pregnancy. More well-designed, large-scale }\end{array}$ \\
\hline
\end{tabular}


Table 1. Characteristics of included systematic reviews (Continued)

helminthics for

soil-transmit-

ted helminths

during preg-

nancy. randomised controlled trials are needed to establish the benefit of antihelminthic treatment during pregnancy.

\begin{tabular}{|c|c|c|c|c|c|}
\hline $\begin{array}{l}\text { Salam 2015b } \\
\text { Impact of } \\
\text { Haemophilus } \\
\text { influenzae type } \\
\text { B (Hib) and vi- } \\
\text { ral influenza } \\
\text { vaccinations } \\
\text { in pregnan- } \\
\text { cy for improv- } \\
\text { ing maternal, } \\
\text { neonatal and } \\
\text { infant health } \\
\text { outcomes. }\end{array}$ & $\begin{array}{l}29 \text { January } \\
2015\end{array}$ & 2 & 2262 & $\begin{array}{l}\text { 1. Perinatal } \\
\text { death } \\
\text { 2. Infant } \\
\text { death } \\
\text { 3. Preterm } \\
\text { birth }\end{array}$ & $\begin{array}{l}\text { There is limited evidence (from one small } \\
\text { trial at a high risk of bias) on the effective- } \\
\text { ness on Hib during pregnancy for improv- } \\
\text { ing maternal, neonatal and infant health } \\
\text { outcomes. Evidence from one large high- } \\
\text { quality trial on the effectiveness of viral } \\
\text { influenza vaccine during pregnancy sug- } \\
\text { gests reduced RT-PCR confirmed influenza } \\
\text { among women and their babies, suggest- } \\
\text { ing the potential of this strategy for scale } \\
\text { up but further evidence from varying con- } \\
\text { texts is required. Further trials for both Hib } \\
\text { and viral influenza vaccines with appropri- } \\
\text { ate study designs and suitable comparison } \\
\text { groups are required. }\end{array}$ \\
\hline
\end{tabular}

Salam 2015c 31 March $2015 \quad 4 \quad 1646 \quad$ None
Pyridoxine (vi-
tamin B6) sup-
plementation
during preg-
nancy or labour
for maternal
and neonatal
outcomes.

There were few trials, reporting few clinical outcomes and mostly with unclear trial methodology and inadequate follow-up. There is not enough evidence to detect clinical benefits of vitamin B6 supplementation in pregnancy and/or labour other than one trial suggesting protection against dental decay. Future trials assessing this and other outcomes such as orofacial clefts, cardiovascular malformations, neurological development, preterm birth pre-eclampsia and adverse events are required.

Sandall $2016 \quad 31$ May $2015 \quad 15 \quad 17,674$
Midwife-led
continuity
models ver-
sus other mod-
els of care for
childbearing
women.
1. Overall fe- tal loss and neona- tal death
2. Preterm birth
This review suggests that women who re- ceived midwife-led continuity models of care were less likely to experience inter- vention and more likely to be satisfied with their care with at least comparable adverse outcomes for women or their infants than women who received other models of care.

Further research is needed to explore findings of fewer preterm births and fewer fetal deaths less than 24 weeks, and all fetal loss/neonatal death associated with midwife-led continuity models of care.

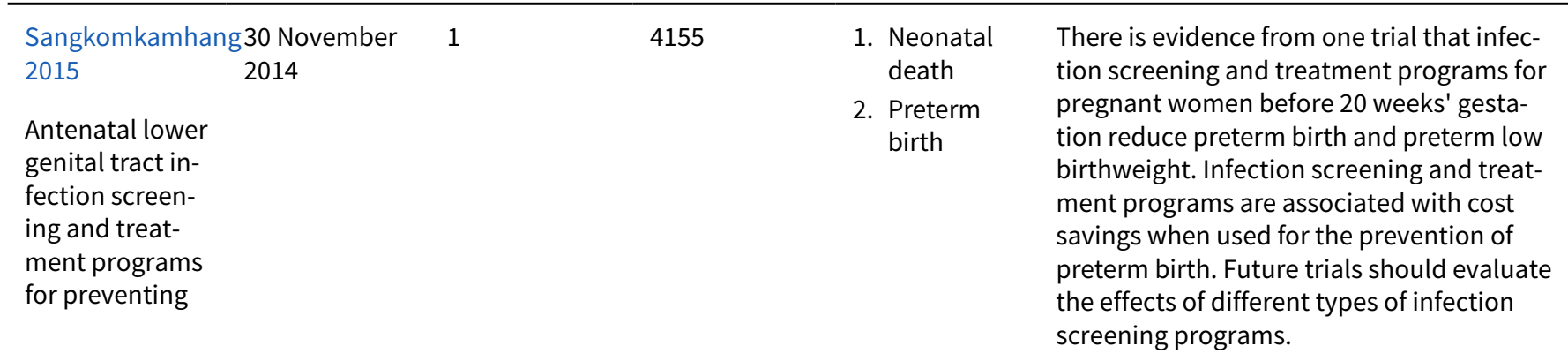

Interventions during pregnancy to prevent preterm birth: an overview of Cochrane systematic reviews (Review) 
Table 1. Characteristics of included systematic reviews (Continued) preterm delivery.

\begin{tabular}{|c|c|c|c|c|c|}
\hline $\begin{array}{l}\text { Schneeberger } \\
2015 \\
\text { Interventions } \\
\text { for preventing } \\
\text { recurrent uri- } \\
\text { nary tract in- } \\
\text { fection during } \\
\text { pregnancy. }\end{array}$ & 20 May 2015 & 1 & 200 & $\begin{array}{l}\text { 1. Miscarriage } \\
\text { 2. Preterm } \\
\text { birth }\end{array}$ & $\begin{array}{l}\text { A daily dose of nitrofurantoin and close } \\
\text { surveillance has not been shown to pre- } \\
\text { vent RUTI compared with close surveil- } \\
\text { lance alone. A significant reduction of ASB } \\
\text { was found in women with a high clinic at- } \\
\text { tendance rate and who received nitrofu- } \\
\text { rantoin and close surveillance. There was } \\
\text { limited reporting of both primary and sec- } \\
\text { ondary outcomes for both women and in- } \\
\text { fants. No conclusions can be drawn regard- } \\
\text { ing the optimal intervention to prevent } \\
\text { RUTI in women who are pregnant. Ran- } \\
\text { domised controlled trials comparing dif- } \\
\text { ferent pharmacological and non-pharma- } \\
\text { cological interventions are necessary to } \\
\text { investigate potentially effective interven- } \\
\text { tions to prevent RUTI in women who are } \\
\text { pregnant. }\end{array}$ \\
\hline
\end{tabular}

\begin{tabular}{|c|c|c|c|c|c|}
\hline $\begin{array}{l}\text { Smaill } 2015 \\
\text { Antibiotics for } \\
\text { asymptomatic } \\
\text { bacteriuria in } \\
\text { pregnancy. }\end{array}$ & 19 March 2015 & 14 & 2000 & $\begin{array}{l}\text { 1. Preterm } \\
\text { birth }\end{array}$ & $\begin{array}{l}\text { While antibiotic treatment is effective in re- } \\
\text { ducing the risk of pyelonephritis in preg- } \\
\text { nancy, the estimate of the effect is very un- } \\
\text { certain because of the very low quality of } \\
\text { the evidence. The reduction in low birth- } \\
\text { weight and preterm birth with antibiotic } \\
\text { treatment is consistent with theories about } \\
\text { the role of infection in adverse pregnan- } \\
\text { cy outcomes, but this association should } \\
\text { be interpreted with caution given the very } \\
\text { poor quality of the included studies. }\end{array}$ \\
\hline
\end{tabular}

$\begin{array}{lllll}\text { Smyth } 2015 & 31 \text { May } 2015 & 7 & 326 & \text { None }\end{array}$

Interventions for varicose veins and leg oedema in pregnancy.
None

There is moderate-quality evidence to suggest that rutosides appear to help relieve the symptoms of varicose veins in late pregnancy. However, this finding is based on one study (69 women) and there are not enough data presented in the study to assess its safety in pregnancy. Reflexology or water immersion appears to help improve symptoms for women with leg oedema, but again this is based on two small studies (43 and 32 women, respectively).

\begin{tabular}{llcc}
\hline Sosa 2015 & $\begin{array}{l}18 \text { December } \\
2014\end{array}$ & 1266 & $\begin{array}{l}\text {. Preterm } \\
\text { birth }\end{array}$ \\
$\begin{array}{l}\text { Bed rest in sin- } \\
\text { gleton preg- }\end{array}$ & & & \\
nancies for & & & \\
preventing & & & \\
preterm birth. & & &
\end{tabular}
There is no evidence, either supporting or refuting the use of bed rest at home or in hospital, to prevent preterm birth. Al- though bed rest in hospital or at home is widely used as the first step of treatment, there is no evidence that this practice could be beneficial. Due to the potential adverse effects that bed rest could have on women and their families, and the in- creased costs for the healthcare system, clinicians should discuss the pros and cons of bed rest to prevent preterm birth. Po- tential benefits and harms should be dis- cussed with women facing an increased


risk of preterm birth. Appropriate research is mandatory. Future trials should evaluate both the effectiveness of bed rest, and the effectiveness of the prescription of bed rest, to prevent preterm birth.

Spencer 2015
Screening and
subsequent
management
for thyroid dys-
function pre-
pregnancy and
during preg-
nancy for im-
proving mater-
nal and infant
health.

14 July $2015 \quad 26,408$

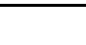

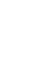

\section{subsequent}

management

for thyroid dys-

function pre-

pregnancy and

during preg-

nancy for im-

nal and infant

health.

1. Fetal and
neonatal
death (re-
ported as a
single out-
come)
2. Miscarriage
3. Preterm
birth
4. Preterm
labour

1. Fetal and

Based on the existing evidence, though universal screening for thyroid dysfunction in pregnancy increases the number of women diagnosed with hypothyroidism who can be subsequently treated, it does not clearly impact (benefit or harm) maternal and infant outcomes. More evidence is needed to assess the benefits or harms of different screening methods for thyroid dysfunction in pregnancy, on maternal, infant and child health outcomes. Future trials should assess impacts on use of health services and costs, and be adequately powered to evaluate the effects on short- and long-term outcomes.

\begin{tabular}{|c|c|c|c|c|c|}
\hline $\begin{array}{l}\text { Suchdev } 2015 \\
\text { Multiple mi- } \\
\text { cronutrient } \\
\text { powders for } \\
\text { home (point- } \\
\text { of-use) fortifi- } \\
\text { cation of foods } \\
\text { in pregnant } \\
\text { women. }\end{array}$ & $\begin{array}{l}31 \text { January } \\
2015\end{array}$ & 2 & 1172 & None & $\begin{array}{l}\text { Limited evidence suggests that micronutri- } \\
\text { ent powders for point-of-use fortification } \\
\text { of foods have no clear difference as multi- } \\
\text { ple micronutrient supplements on mater- } \\
\text { nal anaemia (very low-quality evidence) } \\
\text { and Hb at or near term. There is limited ev- } \\
\text { idence to suggest that women were more } \\
\text { likely to adhere to taking tablets than using } \\
\text { micronutrient powders. }\end{array}$ \\
\hline
\end{tabular}

\begin{tabular}{|c|c|c|c|c|c|}
\hline $\begin{array}{l}\text { Terplan } 2015 \\
\text { Psychosocial } \\
\text { interventions } \\
\text { for pregnant } \\
\text { women in out- } \\
\text { patient illicit } \\
\text { drug treatment } \\
\text { programs com- } \\
\text { pared to other } \\
\text { interventions. }\end{array}$ & January 2015 & 14 & 1298 & $\begin{array}{l}\text { 1. Preterm } \\
\text { birth }\end{array}$ & $\begin{array}{l}\text { The present evidence suggests that there } \\
\text { is no difference in treatment outcomes to } \\
\text { address drug use in pregnant women with } \\
\text { use of psychosocial interventions, when } \\
\text { taken in the presence of other compre- } \\
\text { hensive care options. However, few stud- } \\
\text { ies evaluated obstetrical or neonatal out- } \\
\text { comes and rarely did so in a systematic } \\
\text { way, making it difficult to assess the effect } \\
\text { of psychosocial interventions on these clin- } \\
\text { ically important outcomes. It is important } \\
\text { to develop a better evidence base to eval- } \\
\text { uate psychosocial modalities of treatment } \\
\text { in this important population. }\end{array}$ \\
\hline $\begin{array}{l}\text { Thinkhamrop } \\
2015 \\
\text { Antibiotic pro- } \\
\text { phylaxis during } \\
\text { the second and } \\
\text { third trimester } \\
\text { to reduce ad- } \\
\text { verse pregnan- } \\
\text { cy outcomes } \\
\text { and morbidity. }\end{array}$ & 31 July 2014 & 7 & 2100 & $\begin{array}{l}\text { 1. Perinatal } \\
\text { death } \\
\text { 2. Preterm } \\
\text { birth } \\
\text { 3. Gestational } \\
\text { age at birth }\end{array}$ & $\begin{array}{l}\text { Antibiotic prophylaxis did not reduce the } \\
\text { risk of preterm prelabour rupture of mem- } \\
\text { branes or preterm delivery (apart from in } \\
\text { the subgroup of women with a previous } \\
\text { preterm birth who had bacterial vaginosis). } \\
\text { Antibiotic prophylaxis given during the } \\
\text { second or third trimester of pregnancy re- } \\
\text { duced the risk of postpartum endometri- } \\
\text { tis, term pregnancy with prelabour rup- } \\
\text { ture of membranes and gonococcal infec- } \\
\text { tion when given routinely to all pregnant } \\
\text { women. Substantial bias possibly exists in }\end{array}$ \\
\hline
\end{tabular}


the review's results because of a high rate of loss to follow-up and the small numbers of studies included in each of our analyses. There is also insufficient evidence on possible harmful effects on the baby. Therefore, we conclude that there is not enough evidence to support the use of routine antibiotics during pregnancy to prevent infectious adverse effects on pregnancy outcomes.

Tieu 2017a
Interconcep-
tion care for
women with a
history of ges-
tational dia-
betes for im-
proving mater-
nal and infant
outcomes.

$\begin{array}{llll}7 \text { April } 2017 & 0 & 0 & \text { None }\end{array}$

The role of interconception care for women with a history of GDM remains unclear. Randomised controlled trials are required evaluating different forms and protocols of interconception care for these women on perinatal and long-term maternal and infant health outcomes, acceptability of such interventions and cost-effectiveness.

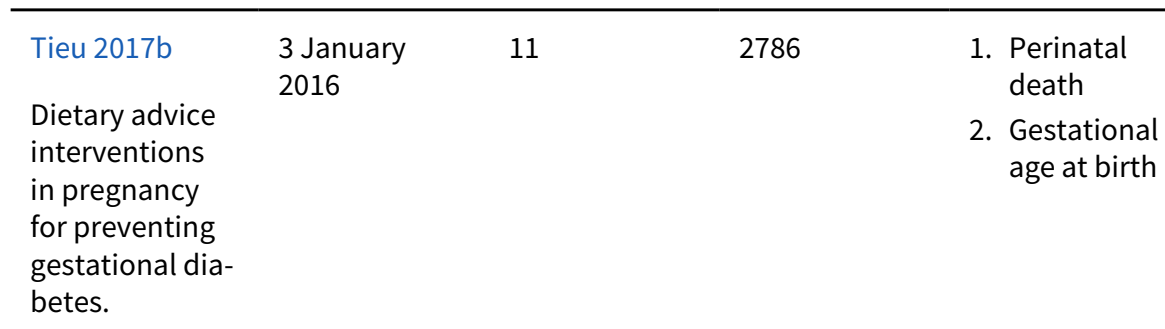
Very low-quality evidence from five tri- als suggests a possible reduction in GDM risk for women receiving dietary advice versus standard care, and low-quality evi- dence from four trials suggests no clear dif- ference for women receiving low- versus moderate- to high-GI dietary advice. A pos- sible reduction in pregnancy-induced hy- pertension for women receiving dietary ad- vice was observed and no clear differences were seen for other reported primary out- comes. There were few outcome data for secondary outcomes. More high-quality ev- idence is needed to determine the effects of dietary advice interventions in pregnan- cy.

Tieu 2017c
Oral anti-dia-
betic agents for
women with es-
tablished dia-
betes/impaired
glucose toler-
ance or previ-
ous gestational
diabetes plan-
ning pregnan-
cy, or pregnant
women with
pre-existing di-
abetes.

\begin{tabular}{lllll}
\hline $\begin{array}{l}\text { Tieu 2017d } \\
\begin{array}{l}\text { 31 January } \\
2017\end{array}\end{array}$ & 4523 & $\begin{array}{l}\text { 1. Perinatal } \\
\text { death }\end{array}$ & $\begin{array}{l}\text { Further, high-quality randomised con- } \\
\text { trolled trials are needed to assess the val- } \\
\text { ue of screening for GDM, which may com- } \\
\text { pare different protocols, guidelines or pro- }\end{array}$ \\
\begin{tabular}{l} 
gestational dia- \\
\hline
\end{tabular}
\end{tabular}

Interventions during pregnancy to prevent preterm birth: an overview of Cochrane systematic reviews (Review)

Copyright @ 2018 The Cochrane Collaboration. Published by John Wiley \& Sons, Ltd.
There are insufficient RCT data to evaluate the use of oral anti-diabetic agents in women with established diabetes, impaired glucose tolerance or previous gestational diabetes who are planning a pregnancy, or in pregnant women with pre-existing diabetes. 
Table 1. Characteristics of included systematic reviews (Continued)

betes mellitus

based on differ-

2. Preterm

ent risk profiles

birth

and settings for

improving ma-

ternal and in-

fant health. grammes for screening (based on different risk profiles and settings), with the absence of screening, or with other protocols, guidelines or programmes. There is a need for future trials to be sufficiently powered to detect important differences in shortand long-term maternal and infant outcomes, such as those important outcomes pre-specified in this review. As only a proportion of women will be diagnosed with GDM in these trials, large sample sizes may be required.

$\begin{array}{lllll}\text { Till } 2015 & 31 \text { January } & 5 & 11,935 & \text { None } \\ \text { Incentives for } & 2015 & & & \end{array}$

increasing pre-

natal care use

by women in

order to im-

prove maternal

and neonatal

outcomes.

The included studies did not report on this review's main outcomes: preterm birth, small-for-gestational age, or perinatal death. There is limited evidence that incentives may increase utilisation and quality of prenatal care, but may also increase caesarean rate. Overall, there is insufficient evidence to fully evaluate the impact of incentives on prenatal care initiation. There is a need for high-quality RCTs to determine whether incentive program increase prenatal care use and improve maternal and neonatal outcomes. Incentive programs, in particular cash-based programs, as suggested in this review and in several observational studies may improve the frequency and ensure adequate quality of prenatal care.

\begin{tabular}{llcl}
\hline $\begin{array}{l}\text { Urquhart } 2017 \\
\text { 30 June 2016 }\end{array}$ & 15 & 6008 & $\begin{array}{l}\text { 1. Perinatal } \\
\text { death }\end{array}$ \\
$\begin{array}{l}\text { Home uter- } \\
\text { ine monitoring }\end{array}$ & & 2. Preterm \\
for detecting & & birth \\
preterm labour. & &
\end{tabular}

Home uterine monitoring may result in fewer admissions to a neonatal intensive care unit, but in more unscheduled antenatal visits and tocolytic treatment; the level of evidence is generally low to moderate. Important group differences were not evident when we undertook sensitivity analysis using only trials at low risk of bias. There is no impact on maternal and perinatal outcomes such as perinatal mortality or incidence of preterm birth.

\begin{tabular}{|c|c|c|c|c|c|}
\hline $\begin{array}{l}\text { Widmer } 2015 \\
\text { Duration of } \\
\text { treatment for } \\
\text { asymptomatic } \\
\text { bacteriuria dur- } \\
\text { ing pregnancy. }\end{array}$ & $\begin{array}{l}31 \text { August } \\
2015\end{array}$ & 13 & 1622 & $\begin{array}{l}\text { 1. Preterm } \\
\text { birth }\end{array}$ & $\begin{array}{l}\text { A single-dose regimen of antibiotics may } \\
\text { be less effective than a short course (four- } \\
\text { to seven-day) regimen, but more evidence } \\
\text { is needed from large trials measuring } \\
\text { important outcomes, such as cure rate. } \\
\text { Women with asymptomatic bacteriuria in } \\
\text { pregnancy should be treated by the stan- } \\
\text { dard regimen of antibiotics until more data } \\
\text { become available testing seven-day treat- } \\
\text { ment compared with shorter courses of } \\
\text { three- or five-day regimens. }\end{array}$ \\
\hline $\begin{array}{l}\text { Wiysonge } 2017 \\
\text { Vitamin A sup- } \\
\text { plements for re- }\end{array}$ & $\begin{array}{l}7 \text { September } \\
2017\end{array}$ & 5 & 7298 & $\begin{array}{l}\text { 1. Preterm } \\
\text { birth }\end{array}$ & $\begin{array}{l}\text { Antepartum or postpartum vitamin A sup- } \\
\text { plementation, or both, probably has little } \\
\text { or no effect on mother-to-child transmis- } \\
\text { sion of HIV in women living with HIV infec- }\end{array}$ \\
\hline
\end{tabular}


Table 1. Characteristics of included systematic reviews (Continued) ducing mother-to-child HIV transmission. tion and not on antiretroviral drugs. The intervention has largely been superseded by ART which is widely available and effective in preventing vertical transmission.

\begin{tabular}{|c|c|c|c|c|c|}
\hline $\begin{array}{l}\text { Yamasmit } 2015 \\
\text { Prophylac- } \\
\text { tic oral be- } \\
\text { tamimetics } \\
\text { for reducing } \\
\text { preterm birth in } \\
\text { women with a } \\
\text { twin pregnan- } \\
\text { cy. }\end{array}$ & $\begin{array}{l}21 \text { September } \\
2015\end{array}$ & 6 & 374 & $\begin{array}{l}\text { 1. Neonatal } \\
\text { death } \\
\text { 2. Preterm } \\
\text { labour } \\
\text { 3. Preterm } \\
\text { birth }\end{array}$ & $\begin{array}{l}\text { There is insufficient evidence to support } \\
\text { or refute the use of prophylactic oral be- } \\
\text { tamimetics for preventing preterm birth in } \\
\text { women with a twin pregnancy. }\end{array}$ \\
\hline $\begin{array}{l}\text { Zhou } 2015 \\
\text { Interventions } \\
\text { for leg cramps } \\
\text { in pregnancy. }\end{array}$ & 31 March 2015 & 6 & 390 & None & $\begin{array}{l}\text { It is unclear from the evidence reviewed } \\
\text { whether any of the interventions (oral } \\
\text { magnesium, oral calcium, oral vitamin B or } \\
\text { oral vitamin C) provide an effective treat- } \\
\text { ment for leg cramps. This is primarily due } \\
\text { to outcomes being measured and reported } \\
\text { in different, incomparable ways, and de- } \\
\text { sign limitations compromising the quality } \\
\text { of the evidence (the level of evidence was } \\
\text { graded low or very low). This was mainly } \\
\text { due to poor study design and trials being } \\
\text { too small to address the question satisfac- } \\
\text { torily. }\end{array}$ \\
\hline
\end{tabular}

ANC: antenatal care

ART: antiretroviral therapy

ASB: asymptomatic bacteriuria

CTG: cardiotocography

DASH: Dietary Approaches to Stop Hypertension

ECV: external cephalic version

FBG: fasting blood glucose

GA: gestational age

GDM: gestational diabetes mellitus

GWG: gestational weight gain

$\mathrm{Hb}$ : haemoglobin

HELLP: haemolysis, elevated liver enzymes, low platelets

hpl: human placental lactogen

LGA: large-for-gestational age

MMN: multiple-micronutrient

NRT: nicotine replacement therapy

PROM: prelabour rupture of membranes

$\mathrm{RCT}$ : randomised controlled trial

RT-PCR: reverse-transcriptase-polymerase-chain-reaction

RUTI: recurrent urinary tract infections

UTI: urinary tract infection

Table 2. Excluded systematic reviews

$\begin{array}{lll}\text { Review ID Review title Reason for exclusion } & \end{array}$




\section{Table 2. Excluded systematic reviews (Continued)}

\begin{abstract}
Amaya-Guio 2016
Antibiotic treatment for the sexual partners of

Antibiotic treatment for the sexual partners of
women with bacterial vaginosis.
\end{abstract}

\begin{tabular}{ll}
\hline Balogun 2016a & $\begin{array}{l}\text { Vitamin supplementation for preventing miscar- } \\
\text { riage. }\end{array}$
\end{tabular}

Balogun 2016b Interventions for initiation of breastfeeding.

The review does not report results for pregnant women; the intervention does not target health providers.

Reviews targets miscarriage in early pregnancy.
Overview outcomes of preterm birth and perinatal death are not specified as review outcomes. Review concerned with post-pregnancy outcomes.

\begin{tabular}{ll}
\hline Chi 2015 & Safety of topical corticosteroids in pregnancy. \\
\hline Demicheli 2015 & Vaccines for women for preventing neonatal tetanus. \\
\hline Dickinson 2014 & $\begin{array}{l}\text { Creatine for women in pregnancy for neuroprotec- } \\
\text { tion of the fetus. }\end{array}$ \\
\hline Frazer 2016 & $\begin{array}{l}\text { Legislative smoking bans for reducing harms from } \\
\text { secondhand smoke exposure, smoking prevalence } \\
\text { and tobacco consumption. }\end{array}$ \\
\hline Grivell 2014 & $\begin{array}{l}\text { Prenatal versus postnatal repair procedures for } \\
\text { spina bifida for improving infant and maternal out- } \\
\text { comes. }\end{array}$ \\
\hline Hemmingsen 2017 & $\begin{array}{l}\text { Dipeptidyl-peptidase (DPP)-4 inhibitors and } \\
\text { glucagon-like peptide (GLP)-1 analogues for preven- } \\
\text { tion or delay of type 2 diabetes mellitus and its asso- } \\
\text { ciated complications in people at increased risk for } \\
\text { the development of type 2 diabetes mellitus. }\end{array}$
\end{tabular}

All evidence is from cohort studies

Heslop 2016 Interventions for men and women with their first episode of genital herpes.

Evidence for the effectiveness of smoking bans to impact preterm birth comes from non-randomised study designs.

Intervention targets pregnant women with major fetal abnormality.

Pregnant women are excluded from many of the trials included in this review.

The intervention targets the neonate.

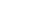
Data are not reported for pregnant women. Preg-
nancy was an exclusion criteria for several includ-
ed clinical trials. The intervention does not target
healthcare providers.

\begin{tabular}{lll}
\hline Jahanfar 2017 & $\begin{array}{l}\text { Ultrasound for diagnosis of birthweight discordance } \\
\text { in twin pregnancies (Protocol). }\end{array}$ & $\begin{array}{l}\text { This is a DTA review and no outcome data rele- } \\
\text { vant to the overview are planned. }\end{array}$ \\
\hline Karanth 2015 & $\begin{array}{l}\text { Desmopressin acetate (DDAVP) for preventing and } \\
\text { treating acute bleeds during pregnancy in women } \\
\text { with congenital bleeding. }\end{array}$ & Preterm birth is not a review outcome. \\
\hline Khattri 2017 & $\begin{array}{l}\text { Adjunctive systemic antimicrobials for the non-sur- } \\
\text { gical treatment of chronic and aggressive periodon- } \\
\text { titis (Protocol). }\end{array}$ & $\begin{array}{l}\text { Pregnant women are excluded from this review } \\
\text { protocol. }\end{array}$ \\
\hline Li 2014 & $\begin{array}{l}\text { Periodontal therapy for the management of cardio- } \\
\text { vascular disease in patients with chronic periodonti- } \\
\text { tis. }\end{array}$ & $\begin{array}{l}\text { Pregnant women were not eligible for this re- } \\
\text { view. The intervention does not target healthcare } \\
\text { providers. }\end{array}$ \\
\hline Li 2016 & $\begin{array}{l}\text { Chinese herbal medicines for unexplained recurrent } \\
\text { miscarriage. }\end{array}$ & $\begin{array}{l}\text { This review is concerned with recurrent miscar- } \\
\text { riage in early pregnancy. }\end{array}$ \\
\hline Liddle 2015 & $\begin{array}{l}\text { Interventions for preventing and treating low-back } \\
\text { and pelvic pain during pregnancy. }\end{array}$ & $\begin{array}{l}\text { Preterm birth and perinatal death are not speci- } \\
\text { fied as review outcomes. }\end{array}$ \\
\hline \hline
\end{tabular}




\section{Table 2. Excluded systematic reviews (Continued)}

\section{Martineau $2016 \quad$ Vitamin D for the management of asthma.}

This review included children and adults. There is no indication that pregnant women were included or excluded from the review.

This review is not specific to a pregnant population and no pregnancy outcomes are specified.

Preterm birth mentioned in the text; only nonrandomised data presented in the discussion.

$\begin{array}{lll}\text { Okusanya } 2016 & \begin{array}{l}\text { Prophylactic versus selective blood transfusion for } \\ \text { sickle cell disease in pregnancy. }\end{array} & \begin{array}{l}\text { Preterm birth mentioned in the text; only non- } \\ \text { randomised data presented in the discussion. }\end{array}\end{array}$

\begin{tabular}{|c|c|c|}
\hline Stock 2016 & $\begin{array}{l}\text { Immediate versus deferred delivery of the preterm } \\
\text { baby with suspected fetal compromise for improv- } \\
\text { ing outcomes. }\end{array}$ & $\begin{array}{l}\text { Pregnant women included in this review were ex- } \\
\text { pected to deliver preterm. }\end{array}$ \\
\hline Tieu $2017 f$ & $\begin{array}{l}\text { Preconception care for diabetic women for improv- } \\
\text { ing maternal and infant health. }\end{array}$ & $\begin{array}{l}\text { Intervention limited to the preconception period } \\
\text { and targeted women who were not pregnant. PTB } \\
\text { is a review outcome. }\end{array}$ \\
\hline Weston 2016 & $\begin{array}{l}\text { Monotherapy treatment of epilepsy in pregnancy: } \\
\text { congenital malformation outcomes in the child. }\end{array}$ & $\begin{array}{l}\text { This review is concerned with outcomes for the } \\
\text { neonate and child. }\end{array}$ \\
\hline Whitworth 2015 & Ultrasound for fetal assessment in early pregnancy. & $\begin{array}{l}\text { This review does not cover the use of ultrasound } \\
\text { to identify women at risk of preterm birth; that } \\
\text { topic is covered in another review. }\end{array}$ \\
\hline Wilkinson 2016 & $\begin{array}{l}\text { Melatonin for women in pregnancy for neuroprotec- } \\
\text { tion of the fetus. }\end{array}$ & $\begin{array}{l}\text { The intervention in this review targets the health } \\
\text { of the neonate. }\end{array}$ \\
\hline
\end{tabular}

DTA: diagnostic test accuracy

PTB: preterm birth

\section{APPENDICES}

\section{Appendix 1. Search strategy}

Date Run: 02/11/17 15:23:15.642

\#1 preterm near birth* 2798

\#2 preterm near lab*r 1164

\#3 preterm near delivery 1213

\#4 pre-term near birth ${ }^{\star} 161$

\#5 pre-term near delivery 89

\#6 premature near birth* 2067

\#7 pre-term near lab*r 55

\#8 premature near delivery 319

\#9 premature near lab*r 2029

\#10 MeSH descriptor: [Premature Birth] explode all trees 582

\#11 MeSH descriptor: [Obstetric Labor, Premature] explode all trees 1329

\#12 \#1 or \#2 or \#3 or \#4 or \#5 or \#6 or \#7 or \#8 or \#9 or \#10 or \#11 5913

Interventions during pregnancy to prevent preterm birth: an overview of Cochrane systematic reviews (Review) 
Limit to Cochrane reviews and protocols

898 Cochrane reviews or protocols

\section{Appendix 2. Eligible but out of date systematic reviews}

1. Abalos E, Duley L, Steyn DW. Antihypertensive drug therapy for mild to moderate hypertension during pregnancy. Cochrane Database of Systematic Reviews 2014, Issue 2. [DOI: 10.1002/14651858.CD002252.pub3]

2. Abdel-Aleem H, Shaaban OM, Abdel-Aleem MA. Cervical pessary for preventing preterm birth. Cochrane Database of Systematic Reviews 2013, Issue 5. [DOI: 10.1002/14651858.CD007873.pub3]

3. Alexander S, Boulvain M, Ceysens G, Haelterman E, Zhang W-H. Repeat digital cervical assessment in pregnancy for identifying women at risk of preterm labour. Cochrane Database of Systematic Reviews 2010, Issue 6. [DOI: 10.1002/14651858.CD005940.pub2]

4. Barrett HL, Dekker NM, Conwell LS, Callaway LK. Probiotics for preventing gestational diabetes. Cochrane Database of Systematic Reviews 2014, Issue 2. [DOI: 10.1002/14651858.CD009951.pub2]

5. Bergamaschi DP, Mariath AB, Abbade JF, Grillo LP, Diniz CS, Hinnig PF. Selenium supplementation during pregnancy for improving maternal and newborn outcomes. Cochrane Database of Systematic Reviews 2012, Issue 3. [DOI: 10.1002/14651858.CD009673]

6. Berghella V, Baxter JK, Hendrix NW. Cervical assessment by ultrasound for preventing preterm delivery. Cochrane Database of Systematic Reviews 2013, Issue 1. [DOI: 1002/14651858.CD007235.pub3]

7. Berghella V, Hayes E, Visintine J, Baxter JK. Fetal fibronectin testing for reducing the risk of preterm birth. Cochrane Database of Systematic Reviews 2008, Issue 4. [DOI: 1002/14651858.CD006843.pub2]

8. Brocklehurst P, Gordon A, Heatley E, Milan SJ. Antibiotics for treating bacterial vaginosis in pregnancy. Cochrane Database of Systematic Reviews 2013, Issue 1. [DOI: 10.1002/14651858.CD000262.pub4]

9. Carlin AJ, Alfirevic Z, Gyte GM. Interventions for treating peripartum cardiomyopathy to improve outcomes for women and babies. Cochrane Database of Systematic Reviews 2010, Issue 9. [DOI: 10.1002/14651858.CD008589.pub2]

10. Churchill D, Beevers GD, Meher S, Rhodes C. Diuretics for preventing pre-eclampsia. Cochrane Database of Systematic Reviews 2007, Issue 1. [DOI: 10.1002/14651858.CD004451.pub2]

11. Churchill D, Duley L, Thornton JG, Jones L. Interventionist versus expectant care for severe pre-eclampsia between 24 and 34 weeks' gestation. Cochrane Database of Systematic Reviews 2013, Issue 7. [DOI: 1002/14651858.CD003106.pub2]

12. Dennis C-L, Dowswell T. Interventions (other than pharmacological, psychosocial or psychological) for treating antenatal depression. Cochrane Database of Systematic Reviews 2013, Issue 7. [DOI: 10.1002/14651858.CD006795.pub3]

13. Dennis C-L, Ross LE, Grigoriadis S. Psychosocial and psychological interventions for treating antenatal depression. Cochrane Database of Systematic Reviews 2007, Issue 3. [DOI: 10.1002/14651858.CD006309.pub2]

14. Dodd JM, McLeod A, Windrim RC, Kingdom J. Antithrombotic therapy for improving maternal or infant health outcomes in women considered at risk of placental dysfunction. Cochrane Database of Systematic Reviews 2013, Issue 7. [DOI: 10.1002/14651858.CD006780.pub3]

15. Dowswell T, Middleton P, Weeks A. Antenatal day care units versus hospital admission for women with complicated pregnancy. Cochrane Database of Systematic Reviews 2009, Issue 4. [DOI: 10.1002/14651858.CD001803.pub2]

16. Duley L, Gülmezoglu AM, Henderson-Smart DJ, Chou D. Magnesium sulphate and other anticonvulsants for women with pre-eclampsia. Cochrane Database of Systematic Reviews 2010, Issue 11. [DOI: 1002/14651858.CD000025.pub2]

17. Duley L, Henderson-Smart DJ, Chou D. Magnesium sulphate versus phenytoin for eclampsia. Cochrane Database of Systematic Reviews 2010, Issue 10. [DOI: 1002/14651858.CD000128.pub2]

18. Duley L, Henderson-Smart DJ, Meher S. Altered dietary salt for preventing pre-eclampsia, and its complications. Cochrane Database of Systematic Reviews 2005, Issue 4. [DOI: 1002/14651858.CD005548]

19. Duley L, Henderson-Smart DJ, Meher S, King JF. Antiplatelet agents for preventing pre-eclampsia and its complications. Cochrane Database of Systematic Reviews 2007, Issue 2. [DOI: 1002/14651858.CD004659.pub2]

20. Duley L, Henderson-Smart DJ, Walker GJ, Chou D. Magnesium sulphate versus diazepam for eclampsia. Cochrane Database of Systematic Reviews 2010, Issue 12. [DOI: 1002/14651858.CD000127.pub2] 
21. Duley L, Matar HE, Almerie MQ, Hall DR. Alternative magnesium sulphate regimens for women with pre-eclampsia and eclampsia. Cochrane Database of Systematic Reviews 2010, Issue 8. [DOI: 1002/14651858.CD007388.pub2]

22. Duley L, Meher S, Jones L. Drugs for treatment of very high blood pressure during pregnancy. Cochrane Database of Systematic Reviews 2013, Issue 7. [DOI: 1002/14651858.CD001449.pub3]

23. Duley L, Williams J, Henderson-Smart DJ. Plasma volume expansion for treatment of pre-eclampsia. Cochrane Database of Systematic Reviews 1999, Issue 4. [DOI: 1002/14651858.CD001805]

24. Eames AJ, Grivell RM, Deussen AR, Hague W, Dodd JM. Metformin for women who are obese during pregnancy for improving maternal and infant outcomes. Cochrane Database of Systematic Reviews 2013, Issue 6. [DOI: 1002/14651858.CD010564]

25. Earl R, Crowther CA, Middleton P. Interventions for hyperthyroidism pre-pregnancy and during pregnancy. Cochrane Database of Systematic Reviews 2013, Issue 11. [DOI: 1002/14651858.CD008633.pub3]

26. Furber CM, McGowan L, Bower P, Kontopantelis E, Quenby S, Lavender T. Antenatal interventions for reducing weight in obese women for improving pregnancy outcome. Cochrane Database of Systematic Reviews 2013, Issue 1. [DOI: 1002/14651858.CD009334.pub2]

27. Gagnon AJ, Sandall J. Individual or group antenatal education for childbirth or parenthood, or both. Cochrane Database of Systematic Reviews 2007, Issue 3. [DOI: 1002/14651858.CD002869.pub2]

28. Gamble CL, Ekwaru JP, ter KFO. Insecticide-treated nets for preventing malaria in pregnancy. Cochrane Database of Systematic Reviews 2006, Issue 2. [DOI: 1002/14651858.CD003755.pub2]

29. Grivell RM, Wong L, Bhatia V. Regimens of fetal surveillance for impaired fetal growth. Cochrane Database of Systematic Reviews 2012, Issue 6. [DOI: 1002/14651858.CD007113.pub3]

30. Guinto VT, De Guia B, Festin MR, Dowswell T. Different antibiotic regimens for treating asymptomatic bacteriuria in pregnancy. Cochrane Database of Systematic Reviews 2010, Issue 9. [DOI: 1002/14651858.CD007855.pub2]

31. Gülmezoglu AM, Azhar M. Interventions for trichomoniasis in pregnancy. Cochrane Database of Systematic Reviews 2011, Issue 5. [DOI: 1002/14651858.CD000220.pub2]

32. Gurung V, Stokes M, Middleton P, Milan SJ, Hague W, Thornton JG. Interventions for treating cholestasis in pregnancy. Cochrane Database of Systematic Reviews 2013, Issue 6. [DOI: 1002/14651858.CD000493.pub2]

33. Han S, Crowther CA, Middleton P. Interventions for pregnant women with hyperglycaemia not meeting gestational diabetes and type 2 diabetes diagnostic criteria. Cochrane Database of Systematic Reviews 2012, Issue 1. [DOI: 1002/14651858.CD009037.pub2]

34. Han S, Middleton P, Crowther CA. Exercise for pregnant women for preventing gestational diabetes mellitus. Cochrane Database of Systematic Reviews 2012, Issue 7. [DOI: 1002/14651858.CD009021.pub2]

35. Henriquez DD, Roos-Hesselink JW, Schalij MJ, Klautz RJ, Helmerhorst FM, de Groot CJ. Treatment of valvular heart disease during pregnancy for improving maternal and neonatal outcome. Cochrane Database of Systematic Reviews 2011, Issue 5. [DOI: 1002/14651858.CD008128.pub2]

36. Hodnett ED, Fredericks S, Weston J. Support during pregnancy for women at increased risk of low birthweight babies. Cochrane Database of Systematic Reviews 2010, Issue 6. [DOI: 1002/14651858.CD000198.pub2]

37. Jefferys AE, Siassakos D, Draycott T, Akande VA, Fox R. Deflation of gastric band balloon in pregnancy for improving outcomes. Cochrane Database of Systematic Reviews 2013, Issue 4. [DOI: 1002/14651858.CD010048.pub2]

38. Jepson RG, Williams G, Craig JC. Cranberries for preventing urinary tract infections. Cochrane Database of Systematic Reviews 2012, Issue 10. [DOI: 1002/14651858.CD001321.pub5]

39. Khanprakob T, Laopaiboon M, Lumbiganon P, Sangkomkamhang US. Cyclo-oxygenase (COX) inhibitors for preventing preterm labour. Cochrane Database of Systematic Reviews 2012, Issue 10. [DOI: 1002/14651858.CD007748.pub2]

40. Khianman B, Pattanittum P, Thinkhamrop J, Lumbiganon P. Relaxation therapy for preventing and treating preterm labour. Cochrane Database of Systematic Reviews 2012, Issue 8. [DOI: 1002/14651858.CD007426.pub2]

41. Khunpradit S, Tavender E, Lumbiganon P, Laopaiboon M, Wasiak J, Gruen RL. Non-clinical interventions for reducing unnecessary caesarean section. Cochrane Database of Systematic Reviews 2011, Issue 6. [DOI: 1002/14651858.CD005528.pub2]

42. Kramer MS, McDonald SW. Aerobic exercise for women during pregnancy. Cochrane Database of Systematic Reviews 2006, Issue 3. [DOI: 1002/14651858.CD000180.pub2] 
43. Lalor JG, Fawole B, Alfirevic Z, Devane D. Biophysical profile for fetal assessment in high risk pregnancies. Cochrane Database of Systematic Reviews 2008, Issue 1. [DOI: 1002/14651858.CD000038.pub2]

44. Lassi ZS, Salam RA, Haider BA, Bhutta ZA. Folic acid supplementation during pregnancy for maternal health and pregnancy outcomes. Cochrane Database of Systematic Reviews 2013, Issue 3. [DOI: 1002/14651858.CD006896.pub2]

45. Lavender T, Richens Y, Milan SJ, Smyth RM, Dowswell T. Telephone support for women during pregnancy and the first six weeks postpartum. Cochrane Database of Systematic Reviews 2013, Issue 7. [DOI: 1002/14651858.CD009338.pub2]

46. Lewin S, Munabi-Babigumira S, Glenton C, Daniels K, Bosch-Capblanch X, van WBE, et al. Lay health workers in primary and community health care for maternal and child health and the management of infectious diseases. Cochrane Database of Systematic Reviews 2010 , Issue 3. [DOI: 1002/14651858.CD004015.pub3]

47. Lim DC, Cheng LN, Zahid S, Wong FW. Prostaglandin A for treating pre-eclampsia. Cochrane Database of Systematic Reviews 2012, Issue 2. [DOI: 1002/14651858.CD009657]

48. Lindegren ML, Kennedy CE, Bain-Brickley D, Azman H, Creanga AA, Butler LM, et al. Integration of HIV/AIDS services with maternal, neonatal and child health, nutrition, and family planning services. Cochrane Database of Systematic Reviews 2012, Issue 9. [DOI: 1002/14651858.CD010119]

49. Lui S, Terplan M, Smith EJ. Psychosocial interventions for women enrolled in alcohol treatment during pregnancy. Cochrane Database of Systematic Reviews 2008, Issue 3. [DOI: 1002/14651858.CD006753.pub2]

50. Macdonald G, Bennett C, Higgins JP, Dennis JA. Home visiting for socially disadvantaged mothers. Cochrane Database of Systematic Reviews 2010, Issue 10. [DOI: 1002/14651858.CD008784]

51. Magee L, Duley L. Oral beta-blockers for mild to moderate hypertension during pregnancy. Cochrane Database of Systematic Reviews 2003, Issue 3. [DOI: 1002/14651858.CD002863]

52. Makrides M, Crosby DD, Bain E, Crowther CA. Magnesium supplementation in pregnancy. Cochrane Database of Systematic Reviews 2014, Issue 4. [DOI: 1002/14651858.CD000937.pub2]

53. Makrides M, Duley L, Olsen SF. Marine oil, and other prostaglandin precursor, supplementation for pregnancy uncomplicated by pre-eclampsia or intrauterine growth restriction. Cochrane Database of Systematic Reviews 2006, Issue 3. [DOI: 1002/14651858.CD003402.pub2]

54. Marc I, Toureche N, Ernst E, Hodnett ED, Blanchet C, Dodin S, et al. Mind-body interventions during pregnancy for preventing or treating women's anxiety. Cochrane Database of Systematic Reviews 2011, Issue 7. [DOI: 1002/14651858.CD007559.pub2]

55. Martí-Carvajal AJ, Peña-Martí GE, Comunián-Carrasco G, Martí-Peña AJ. Interventions for treating painful sickle cell crisis during pregnancy. Cochrane Database of Systematic Reviews 2009, Issue 1. [DOI: 1002/14651858.CD006786.pub2]

56. Mathanga DP, Uthman OA, Chinkhumba J. Intermittent preventive treatment regimens for malaria in HIV-positive pregnant women. Cochrane Database of Systematic Reviews 2011, Issue 10. [DOI: 1002/14651858.CD006689.pub2]

57. Meher S, Abalos E, Carroli G. Bed rest with or without hospitalisation for hypertension during pregnancy. Cochrane Database of Systematic Reviews 2005, Issue 4. [DOI: 1002/14651858.CD003514.pub2]

58. Meher S, Duley L. Progesterone for preventing pre-eclampsia and its complications. Cochrane Database of Systematic Reviews 2006, Issue 4. [DOI: 1002/14651858.CD006175]

59. Meher S, Duley L. Rest during pregnancy for preventing pre-eclampsia and its complications in women with normal blood pressure. Cochrane Database of Systematic Reviews 2006, Issue 2. [DOI: 1002/14651858.CD005939]

60. Meher S, Duley L. Exercise or other physical activity for preventing pre-eclampsia and its complications. Cochrane Database of Systematic Reviews 2006, Issue 2. [DOI: 1002/14651858.CD005942]

61. Meher S, Duley L. Garlic for preventing pre-eclampsia and its complications. Cochrane Database of Systematic Reviews 2006 , Issue 3. [DOI: 1002/14651858.CD006065]

62. Meher S, Duley L. Nitric oxide for preventing pre-eclampsia and its complications. Cochrane Database of Systematic Reviews 2007, Issue 2. [DOI: 1002/14651858.CD006490]

63. Miller BJ, Murray L, Beckmann MM, Kent T, Macfarlane B. Dietary supplements for preventing postnatal depression. Cochrane Database of Systematic Reviews 2013, Issue 10. [DOI: 1002/14651858.CD009104.pub2] 
64. Minozzi S, Amato L, Bellisario C, Ferri M, Davoli M. Maintenance agonist treatments for opiate-dependent pregnant women. Cochrane Database of Systematic Reviews 2013, Issue 12. [DOI: 1002/14651858.CD006318.pub3]

65. Mujezinovic F, Alfirevic Z. Technique modifications for reducing the risks from amniocentesis or chorionic villus sampling. Cochrane Database of Systematic Reviews 2012, Issue 8. [DOI: 10.1002/14651858.CD008678.pub2]

66. Nabhan AF, Elsedawy MM. Tight control of mild-moderate pre-existing or non-proteinuric gestational hypertension. Cochrane Database of Systematic Reviews 2011, Issue 7. [DOI: 1002/14651858.CD006907.pub2]

67. Neilson JP. Interventions for suspected placenta praevia. Cochrane Database of Systematic Reviews 2003, Issue 2. [DOI: 1002/14651858.CD001998]

68. Orton LC, Omari AA. Drugs for treating uncomplicated malaria in pregnant women. Cochrane Database of Systematic Reviews 2008, Issue 4. DOI: 10.1002/14651858.CD004912.pub3]

69. Othman M, Alfirevic Z, Neilson JP. Probiotics for preventing preterm labour. Cochrane Database of Systematic Reviews 2007 , Issue 1. [DOI: 1002/14651858.CD005941.pub2]

70. Pasricha S-R, De-Regil LM, Garcia-Casal MN, Burford BJ, Gwirtz JA, Peña-Rosas JP. Fortification of maize flour with iron for preventing anaemia and iron deficiency in populations. Cochrane Database of Systematic Reviews 2012, Issue 11. [DOI: 1002/14651858.CD010187]

71. Quijano CE, Abalos E. Conservative management of symptomatic and/or complicated haemorrhoids in pregnancy and the puerperium. Cochrane Database of Systematic Reviews 2005, Issue 3. [DOI: 1002/14651858.CD004077.pub2]

72. Rayment R, Brunskill SJ, Soothill PW, Roberts DJ, Bussel JB, Murphy MF. Antenatal interventions for fetomaternal alloimmune thrombocytopenia. Cochrane Database of Systematic Reviews 2011, Issue 5. [DOI: 1002/14651858.CD004226.pub3]

73. Raynes-Greenow CH, Roberts CL, Bell JC, Peat B, Gilbert GL, Parker S. Antibiotics for ureaplasma in the vagina in pregnancy. Cochrane Database of Systematic Reviews 2011, Issue 9. [DOI: 1002/14651858.CD003767.pub3]

74. Reid SM, Middleton P, Cossich MC, Crowther CA, Bain E. Interventions for clinical and subclinical hypothyroidism pre-pregnancy and during pregnancy. Cochrane Database of Systematic Reviews 2013, Issue 5. [DOI: 1002/14651858.CD007752.pub3]

75. Reveiz L, Gyte GM, Cuervo LG, Casasbuenas A. Treatments for iron-deficiency anaemia in pregnancy. Cochrane Database of Systematic Reviews 2011, Issue 10. [DOI: 1002/14651858.CD003094.pub3]

76. Rumbold A, Duley L, Crowther CA, Haslam RR. Antioxidants for preventing pre-eclampsia. Cochrane Database of Systematic Reviews 2008, Issue 1. [DOI: 1002/14651858.CD004227.pub3]

77. Say L, Gülmezoglu AM, Hofmeyr GJ. Calcium channel blockers for potential impaired fetal growth. Cochrane Database of Systematic Reviews 1996, Issue 1. [DOI: 1002/14651858.CD000049]

78. Say L, Gülmezoglu AM, Hofmeyr GJ. Bed rest in hospital for suspected impaired fetal growth. Cochrane Database of Systematic Reviews 1996, Issue 1. [DOI: 1002/14651858.CD000034]

79. Self JL, Serdula M, Dowswell T, De-Regil LM. Fortification of condiments and seasonings with iron for preventing anaemia and improving health. Cochrane Database of Systematic Reviews 2012, Issue 2. [DOI: 1002/14651858.CD009604]

80. Shahrook S, Mori R, Ochirbat T, Gomi H. Strategies of testing for syphilis during pregnancy. Cochrane Database of Systematic Reviews 2014, Issue 10. [DOI: 1002/14651858.CD010385.pub2]

81. Sibley LM, Sipe TA, Barry D. Traditional birth attendant training for improving health behaviours and pregnancy outcomes. Cochrane Database of Systematic Reviews 2012, Issue 8. [DOI: 1002/14651858.CD005460.pub3]

82. Siegfried N, Irlam JH, Visser ME, Rollins NN. Micronutrient supplementation in pregnant women with HIV infection. Cochrane Database of Systematic Reviews 2012, Issue 3. [DOI: 1002/14651858.CD009755]

83. Siegfried N, van der Merwe L, Brocklehurst P, Sint TT. Antiretrovirals for reducing the risk of mother-to-child transmission of HIV infection. Cochrane Database of Systematic Reviews 2011, Issue 7. [DOI: 1002/14651858.CD003510.pub3]

84. Stade BC, Bailey C, Dzendoletas D, Sgro M, Dowswell T, Bennett D. Psychological and/or educational interventions for reducing alcohol consumption in pregnant women and women planning pregnancy. Cochrane Database of Systematic Reviews 2009, Issue 2. [DOI: 1002/14651858.CD004228.pub2]

85. Stampalija T, Gyte GM, Alfirevic Z. Utero-placental Doppler ultrasound for improving pregnancy outcome. Cochrane Database of Systematic Reviews 2010, Issue 9. [DOI: 1002/14651858.CD008363.pub2] 
86. Sturt AS, Dokubo EK, Sint TT. Antiretroviral therapy (ART) for treating HIV infection in ART-eligible pregnant women. Cochrane Database of Systematic Reviews 2010, Issue 3. [DOI: 1002/14651858.CD008440]

87. Turnbull C, Osborn DA. Home visits during pregnancy and after birth for women with an alcohol or drug problem. Cochrane Database of Systematic Reviews 2012, Issue 1. [DOI: 1002/14651858.CD004456.pub3]

88. Vazquez JC, Abalos E. Treatments for symptomatic urinary tract infections during pregnancy. Cochrane Database of Systematic Reviews 2011, Issue 1. [DOI: 1002/14651858.CD002256.pub2]

89. Vodopivec-Jamsek V, de JT, Gurol-Urganci I, Atun R, Car J. Mobile phone messaging for preventive health care. Cochrane Database of Systematic Reviews 2012, Issue 12. [DOI: 1002/14651858.CD007457.pub2]

90. Walker GJ. Antibiotics for syphilis diagnosed during pregnancy. Cochrane Database of Systematic Reviews 2001, Issue 3. [DOI: 1002/14651858.CD001143]

91. Walker MC, Ferguson SE, Allen VM. Heparin for pregnant women with acquired or inherited thrombophilias. Cochrane Database of Systematic Reviews 2003, Issue 2. [DOI: 1002/14651858.CD003580]

92. Webb RT, Howard L, Abel KM. Antipsychotic drugs for non-affective psychosis during pregnancy and postpartum. Cochrane Database of Systematic Reviews 2004, Issue 2. [DOI: 1002/14651858.CD004411.pub2]

93. Whitworth M, Dowswell T. Routine pre-pregnancy health promotion for improving pregnancy outcomes. Cochrane Database of Systematic Reviews 2009, Issue 4. [DOI: 1002/14651858.CD007536.pub2]

94. Whitworth M, Quenby S. Prophylactic oral betamimetics for preventing preterm labour in singleton pregnancies. Cochrane Database of Systematic Reviews 2008, Issue 1. [DOI: 1002/14651858.CD006395.pub2]

95. Whitworth M, Quenby S, Cockerill RO, Dowswell T. Specialised antenatal clinics for women with a pregnancy at high risk of preterm birth (excluding multiple pregnancy) to improve maternal and infant outcomes. Cochrane Database of Systematic Reviews 2011 , Issue 9. [DOI: 1002/14651858.CD006760.pub2]

96. Woudstra DM, Chandra S, Hofmeyr GJ, Dowswell T. Corticosteroids for HELLP (hemolysis, elevated liver enzymes, low platelets) syndrome in pregnancy. Cochrane Database of Systematic Reviews 2010, Issue 9. [DOI: 1002/14651858.CD008148.pub2]

\section{CONTRIBUTIONS OF AUTHORS}

ZA, JV, NM and AC designed the study and wrote the protocol. All authors contributed to eligibility assessment, creation of data tables and writing the text for the overview.

\section{DECLARATIONS OF INTEREST}

NM: Nancy Medley's work was financially supported by the University of Liverpool's Harris-Wellbeing of Women Preterm Birth Centre research award. NM was an author on a Cochrane systematic review included in the overview. Assessments for this review was made by another member of the overview team.

JV: none known.

AC: none known.

ZA: Zarko Alfirevic was an author on a Cochrane systematic review included in the overview and also an author on a clinical trial included in an eligible Cochrane systematic review. Assessments for these were made by another member of the overview team. My employer (University of Liverpool) has received grants from UK National Institute of Health Research, Wellbeing of Women charity and Perkin Elmer to support my research group's work related to preterm birth prevention and my Cochrane editorial work.

\section{SOURCES OF SUPPORT}

\section{Internal sources}

- University of Liverpool, UK.

\section{External sources}

- Harris-Wellbeing of Women Preterm Birth Centre, UK. 


\section{N D EX TERMS}

\section{Medical Subject Headings (MeSH)}

${ }^{\star}$ Systematic Reviews as Topic; Anti-Bacterial Agents [therapeutic use]; Bed Rest; Premature Birth [*prevention \& control]; Smoking Cessation; Vitamin D [administration \& dosage]; Vitamins [administration \& dosage]

\section{MeSH check words}

Female; Humans; Pregnancy 